\title{
Poverty and the Labour Market in Indonesia: Employment Trends across the Wealth Distribution
}

Link to publication record in Manchester Research Explorer

\section{Citation for published version (APA):}

Priebe, J., Howell, F., \& Sari, V. A. (2014). Poverty and the Labour Market in Indonesia: Employment Trends across the Wealth Distribution. (TNP2K Working Paper; No. 17-2014).

\section{Citing this paper}

Please note that where the full-text provided on Manchester Research Explorer is the Author Accepted Manuscript or Proof version this may differ from the final Published version. If citing, it is advised that you check and use the publisher's definitive version.

\section{General rights}

Copyright and moral rights for the publications made accessible in the Research Explorer are retained by the authors and/or other copyright owners and it is a condition of accessing publications that users recognise and abide by the legal requirements associated with these rights.

\section{Takedown policy}

If you believe that this document breaches copyright please refer to the University of Manchester's Takedown Procedures [http://man.ac.uk/04Y6Bo] or contact uml.scholarlycommunications@manchester.ac.uk providing relevant details, so we can investigate your claim.

\section{OPEN ACCESS}


POVERTY AND THE LABOUR MARKET IN INDONESIA: EMPLOYMENT TRENDS ACROSS THE WEALTH DISTRIBUTION

JAN PRIEBE, FIONA HOWELL, AND VIRGI AGITA SARI

TNP2K WORKING PAPER 17 - 2014

October 2014

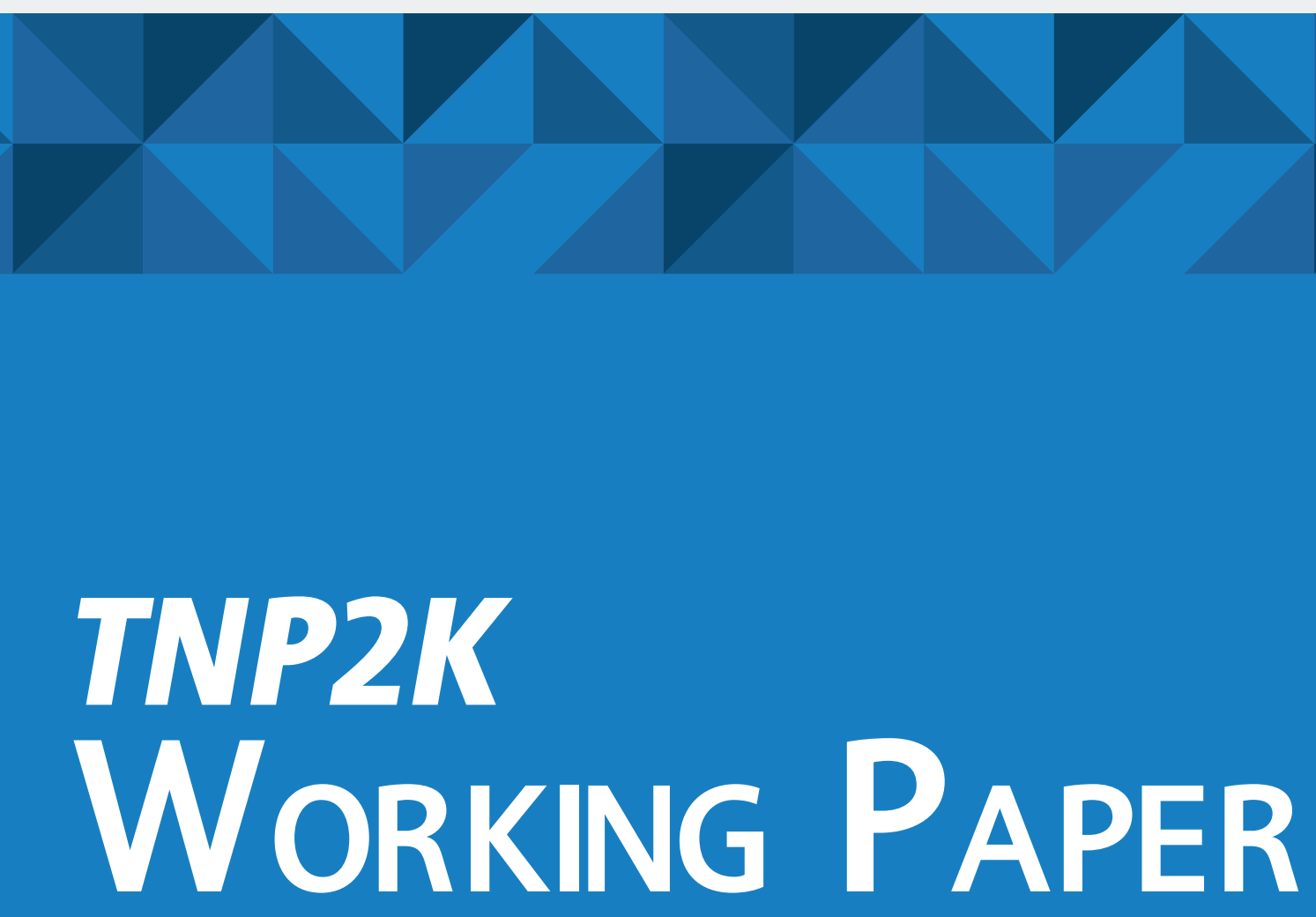

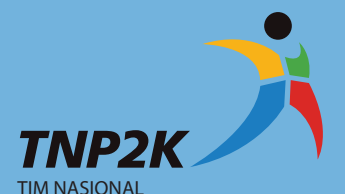

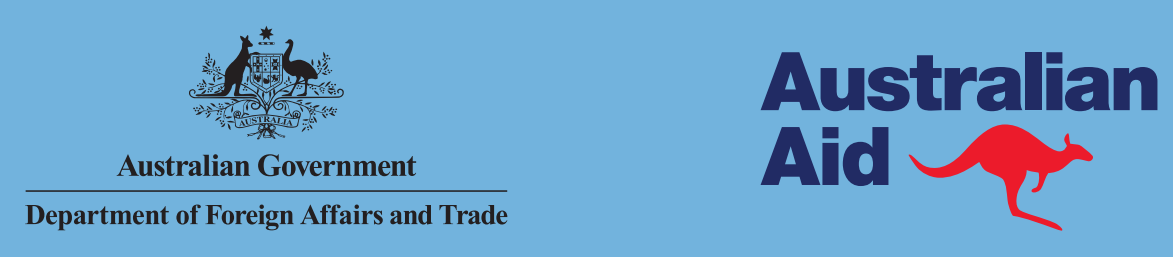





\section{POVERTY AND THE LABOUR MARKET IN INDONESIA: EMPLOYMENT TRENDS ACROSS THE WEALTH DISTRIBUTION}

JAN PRIEBE, FIONA HOWELL, AND VIRGI AGITA SARI

TNP2K WORKING PAPER 17-2014

October 2014

The TNP2K Working Paper Series disseminates the findings of work in progress to encourage discussion and exchange of ideas on poverty, social protection, and development issues.

Support for this publication has been provided by the Australian Government through the Poverty Reduction Support Facility (PRSF).

The findings, interpretations, and conclusions herein are those of the author(s) and do not necessarily reflect the views of the Government of Indonesia or the Government of Australia.

You are free to copy, distribute, and transmit this work for noncommercial purposes.

Suggested citation: Priebe, Jan, Fiona Howell, and Virgi Agita Sari. 2014. 'Poverty and the Labour Market in Indonesia: Employment Trends across the Wealth Distribution'. TNP2K Working Paper 17-2014. Jakarta: Tim Nasional Percepatan Penanggulangan Kemiskinan (TNP2K).

To request copies of the paper or for more information on the paper, please contact the TNP2K Knowledge Management Unit (kmu@tnp2k.go.id). This and other TNP2K working papers are also available at the TNP2K website (www.tnp2k.go.id).

\section{TNP2K}

Grand Kebon Sirih Lt.4, J.Kebon Sirih Raya No.35,

Jakarta Pusat, 10110

Tel: +62 (0) 213912812

Fax: $+62(0) 213912513$

www.tnp2k.go.id 



\title{
Poverty and the Labour Market in Indonesia: Employment Trends across the Wealth Distribution
}

\author{
Jan Priebe, Fiona Howell, and Virgi Agita Sari ${ }^{1}$ \\ October 2014
}

\begin{abstract}
'Poverty and the Labour Market in Indonesia: Employment Trends across the Wealth Distribution', is among Indonesia's first papers on the relationship between poverty and the labour market. It provides a detailed analysis of employment indicators (labour force participation rates, hours worked, and type and sector of employment) for the period 2000-2012 across the entire wealth distribution, by location, gender and various sociodemographic characteristics.
\end{abstract}

Despite high economic growth rates, the creation of millions of new jobs, and a strong decrease in poverty rates in recent years, many Indonesians continue to live in poverty even when employed. This paper finds that the poor are as likely as the nonpoor to work, both at the extensive (labour force participation) and at the intensive (number of days and number of hours) margins. The reason for being poor despite being employed is therefore largely driven by other factors.

In terms of household structure, clear evidence exists that the working poor need to share their income with a larger household, including economically nonactive members such as young children and the elderly. The higher dependency ratio contributes to their being/becoming working poor.

Significant gender differences exist in the Indonesian labour market. Men show higher labour force participation rates and are more likely to work more hours compared with women. However, no strong gender differences were observed when comparing the working poor with the nonpoor.

The authors observed that the relative share of the rural working poor as a portion of all working poor has increased over time and that the majority of the working poor are employed in the agricultural sector. Furthermore, the working poor are predominantly and increasingly (in relative terms) concentrated in the informal sector of the economy.

An important finding concerns the role of education in the likelihood of being poor or nonpoor. Results also suggest that only the attainment of higher secondary and tertiary education seems to increase the likelihood of being meaningfully protected against poverty.

\footnotetext{
${ }^{1}$ The analysis and interpretations presented in this report are those of Jan Priebe (jan.priebe@tnp2k.go.id or jpriebe@unigoettingen.de), Fiona Howell, and Virgi Agita Sari from the Cluster 1 Policy Working Group of TNP2K, who are responsible for any errors and omissions. The authors would like to thank Emma Allen (ILO), Isis Gaddis (World Bank), Stephan Klasen (University of Göttingen), Theo van der Loop (ILO and TNP2K), Suahasil Nazara (TNP2K), Janneke Pieters (Wageningen University), Elan Satriawan (TNP2K), and Sudarno Sumarto (TNP2K) for valuable input and comments and Mercoledi Nikman Nasiir for her outstanding research assistance. The authors are also grateful to Pamela S. Cubberly for her editorial assistance and Purwa Rahmanto for typesetting this work.
} 


\section{Table of Contents}

Abbreviation

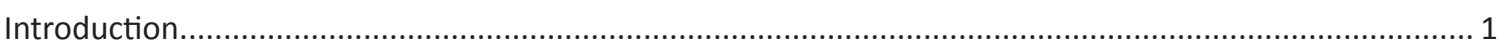

Labour Market Indicators 2000 to 2012: The Rise of Full-Time Employment ........................................... 3

International Differences in Labour Force Participation Rates: The Asia Region .................................... 3

Labour Force Participation, Full-Time Employment, and Underemployment ..................................... 4

Working Hours: Rise in Number of Hours Worked .................................................................... 11

Labour Market Differences among the Working Poor vs. the Working Nonpoor....................................... 13

Labour Force Participation across the Wealth Distribution ............................................................ 13

Working Hours across the Wealth Distribution ............................................................................... 15

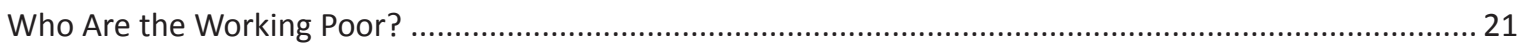

Socioeconomic Characteristics of the Working Poor vs. the Working Nonpoor ....................................2 21

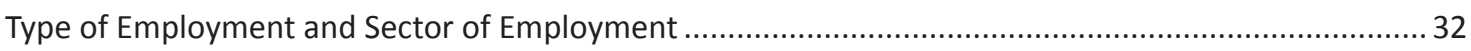

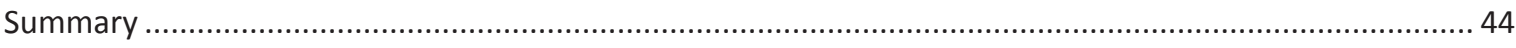

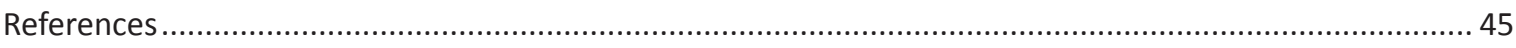

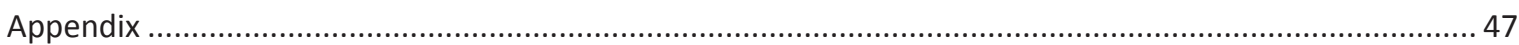




\section{List of Figures}

Figure 1: $\quad$ Labour Force Participation Trends in Asian Countries (1993-2012) ...................................... 3

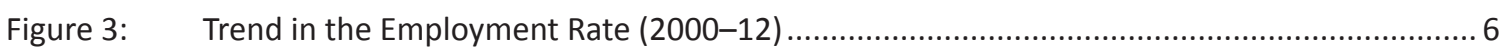

Figure 4: $\quad$ Labour Force Participation by Rural and Urban Area $(2000-12)$........................................ 8

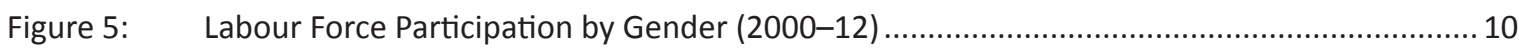

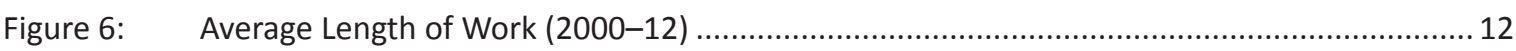

Figure 7: $\quad$ Labour Force Participation by Real per Capita Expenditure Decile (2012) ........................... 14

Figure 8: $\quad$ Trend in Labour Force Participation (Selected Deciles) ...................................................... 15

Figure 9: Employment Status by Real per Capita Expenditure (2012) ............................................. 17

Figure 10: Length of Work by Real per Capita Expenditure (2012) ..................................................... 17

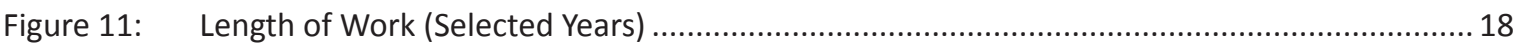

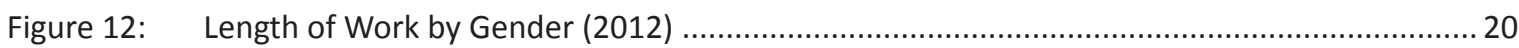

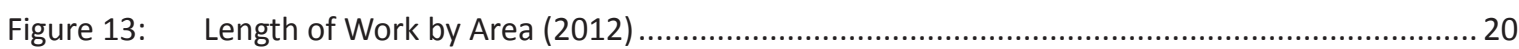

Figure 14: Distribution of Workers by Educational Attainment (2012) .............................................. 24

Figure 15: Distribution of Workers by Educational Attainment (2000-12) ......................................... 25

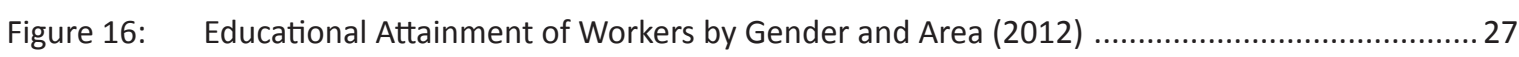

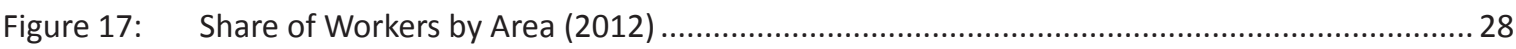

Figure 18: $\quad$ Proportion of Workers by Areas (Selected Deciles) …......................................................... 29

Figure 19: Share of Workers in the Labour Force by Area and Decile ................................................ 30

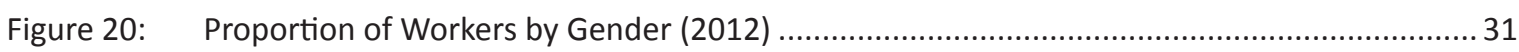

Figure 21: Proportion of Workers by Gender (Selected Deciles, 2000-12) ......................................... 32

Figure 22: Distribution of Workers by Type of Employment (2012) ................................................... 33

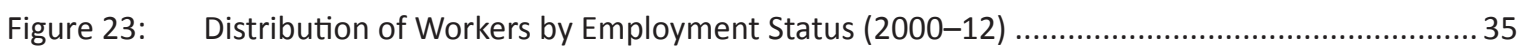

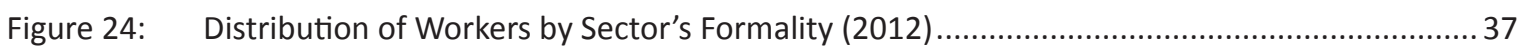

Figure 25: Proportion of Workers by Sector's Formality (Selected Years) ............................................ 38

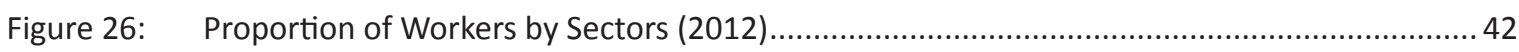

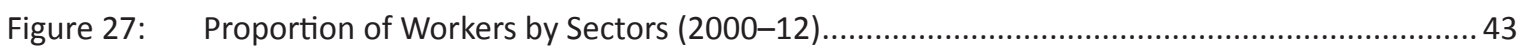




\section{List of Tables}

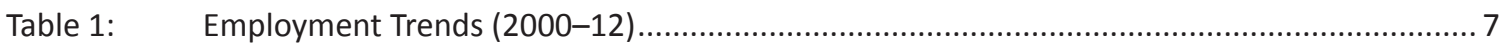

Table 2: $\quad$ Employment Rates by Area (Selected Years) .............................................................. 8

Table 3: $\quad$ Employment Rates by Gender (2000-12) .................................................................. 10

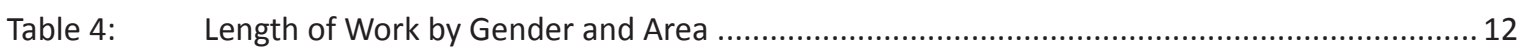

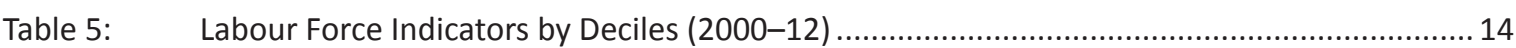

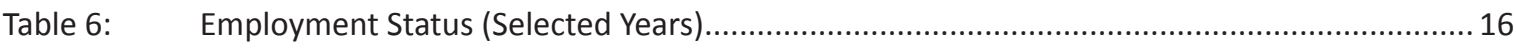

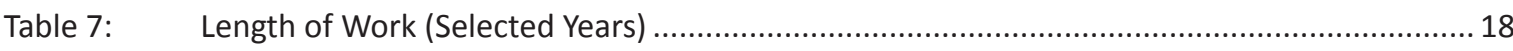

Table 8: $\quad$ Length of Work by Gender and Area (2012) ................................................................ 19

Table 9: $\quad$ Demographic Structure of Working Persons across Deciles (2000-12) ................................. 22

Table 10: Distribution of Workers by Educational Attainment (2000-12) ......................................... 24

Table 10: $\quad$ Distribution of Workers by Educational Attainment (2000-12) [continued] ...........................25

Table 11: $\quad$ Educational Attainment of Workers by Gender and Area (2012) ......................................... 26

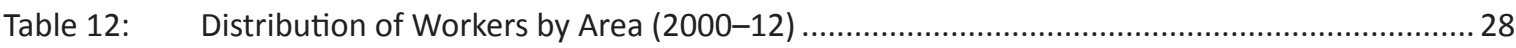

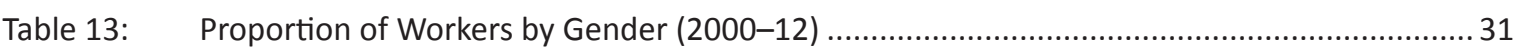

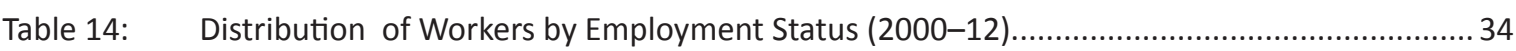

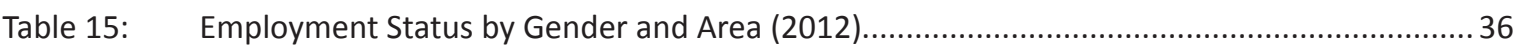

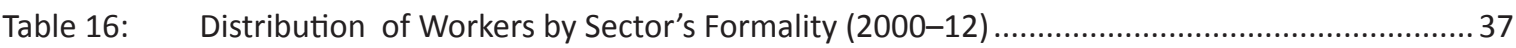

Table 17: $\quad$ Proportion of Workers by Sector's Formality, Gender, and Area (2012) ................................ 39

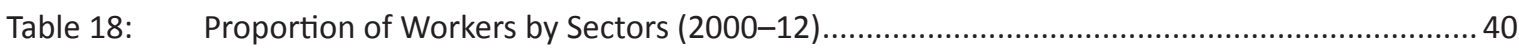

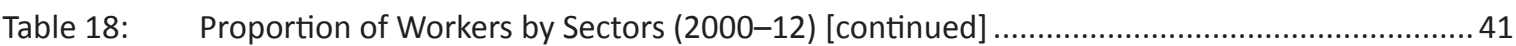

Table A1: $\quad$ Labour Market Indicators according to Statistics Indonesia (2000-12) .................................47

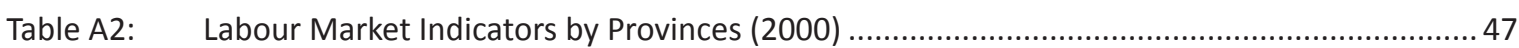

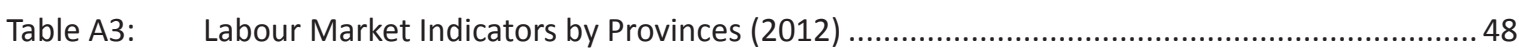

Table A4: $\quad$ The Classification of Sectors by Formality according to Statistics Indonesia .......................... 49 


\section{Abbreviations}

BPS

Badan Pusat Statistik (Statistics Indonesia)

$\mathrm{HH}$

household

ILO

International Labour Organization

LFPR

Labour Force Participation Rate

$\mathrm{n} / \mathrm{a}$

not applicable

OECD

Organisation for Economic Cooperation and Development

Sakernas

Survei Angkatan Kerja Nasional (National Labour Force Survey)

Susenas

Survei Sosial dan Ekonomi Nasional (National Social and Economic Survey)

TNP2K

Tim Nasional Percepatan Penanggulangan Kemiskinan (National Team for the Acceleration of Poverty Reduction) 



\section{Introduction}

After the financial and economic crisis of 1997/1998, Indonesia entered a period of high economic growth with gross domestic product per capita growth rates (in constant prices) averaging $5.4 \%$ between 2000 and 2012. These high economic growth rates were accompanied by strong reductions in poverty rates from $19.14 \%$ in 2000 to $11.66 \%$ in 2012 .

However, despite these positive developments, poverty levels in Indonesia remain high and many millions of individuals and households live just above the widely used near-poor poverty line (1.2 times the poverty line $)^{2}$ and are vulnerable to shocks. As recent reports by the World Bank (2013) and TNP2K (Priebe and Howell 2014) show, about 25\% of households were poor at least once during 2008-10. Likewise, in 2012 about $25.5 \%$ of Indonesians were living below the near-poor poverty line, further illustrating that more than 60 million Indonesians are still considered poor or vulnerable to poverty.

Employment and jobs are instrumental to achieving economic and social development. Beyond their importance for individual well-being, they lie at the heart of many broader social objectives, such as poverty reduction, social cohesion, conflict resolution, and productivity growth. The creation of sustainable employment opportunities has been a focus for governments around the world (World Bank 2013; OECD 2013), not only on job creation but also on creating productive employment that provides decent wages and income so that workers and their families are not prone to poverty. In fact, the main problem for the poor in many developing countries, including Indonesia, is not that they do not have enough hours to work but rather that their jobs are not earning/paying sufficient income for them to make a living. Recognising and acknowledging this issue, many countries in the region, including Indonesia, have committed themselves to national and international strategies to achieve full, productive, and decent employment for all their people. For example, Indonesia has its National LongTerm Development Plan (Rencana Pembangunan Jangka Panjang Nasional) 2005-25 and National Medium-Term Development Plan (Rencana Pembangunan Jangka Menegah Nasional) 2010-14. International examples include the G20 Labour and Employment Ministers' Declaration of July 2013 and the International Labour Organization's (ILO's) Asian-Pacific Decent Work Decade 2006-15.

In this context, it is important to acknowledge several features of labour markets in developing countries, including Indonesia. First, due to increasing population growth, more people are entering than exiting the labour market. Economists and demographers often refer to terms such as a 'demographic dividend' in which the share of people that need to support the nonworking population (young children and the elderly) is supplied by a large number of people of working age; however, the existence and the extent of benefit from such a dividend strongly depends on how successful Indonesia will be in bringing the millions of new young workers into productive and gainful employment (Oberman et al. 2012).

Furthermore, as widely documented, for example, in World Bank (2010), Aswicahyono et al. (2011), Di Gropello et al. (2011), ILO (2012, 2013), and Huynh and Kapsos (2013), the Indonesian labour market is still characterised by high, albeit declining, shares of informal employment; partial compliance with formal labour market legislation (contribution to social security schemes, minimum wages, tax

\footnotetext{
2 Please see World Bank (2012) and Alatas, Purnamasari and Wai-Poi (2012) for other publications using the near-poor poverty line.
} 
payments, and registration of businesses); and a high share of persons working on traditional small rural farms.

To design appropriate labour market policies that contribute to economic growth and poverty reduction, it is important to better understand the composition and development of Indonesia's labour market. This paper is intended to fill this gap by providing a comprehensive analytical overview on key labour market indicators, such as labour force participation rates, employment rates, unemployment rates, and hours and days worked. The respective statistics are calculated and further disaggregated by rural and urban status, gender, and province. Moreover, because the objective of this report is to link work with poverty, wealth distribution and labour market statistics are disaggregated by deciles (based on household per capita ependiture levels) with a particular focus on workers living in the poorest decile (decile 1). By interlinking poverty and labour market statistics, this report provides a unique data source for policy makers and researchers alike that are interested in a deeper understanding of poverty and employment issues in Indonesia.

As the main objective of this report is to analyse the interrelationship of poverty and the labour market, the principal data source used in this report is Indonesia's large-scale national household survey, the National Social and Economic Survey (Survei Sosial dan Ekonomi Nasional or Susenas), which is conducted by Statistics Indonesia (Badan Pusat Statistik or BPS). Susenas is currently the only data source available in Indonesia that collects reliable, nationally representative information on household living standards and labour market characteristics. Although Susenas is the underlying data source for official poverty statistics in Indonesia, the National Labour Force Survey (Survei Angkatan Kerja Nasional or Sakernas) is used by Statistics Indonesia to calculate the official labour market indicators. An important disadvantage of Sakernas for our purpose is that it only provides information on individuals (individuals cannot be linked with other household members) and does not collect information that can be used to identify poor individuals (e.g., expenditure information). That said, Susenas uses exactly the same labour market questions as Sakernas, and labour market indicators included in Susenas are very similar to those of Sakernas. To analyse labour market trends over time, this report focuses on the postfinancial-crisis period and uses the Susenas rounds of 2000, 2003, 2006, 2009, and 2012.

The remainder of this report is organised as follows: Section 2 provides key labour market indicators for the years 2000, 2003, 2006, 2009, and 2012. Section 3 disaggregates labour market indicators by wealth level and discusses the change of the employment structure for the poor vs. the nonpoor. Section 4 describes the socioeconomic characteristics associated with the working poor vs. the nonpoor, and section 5 summarizes the main findings and provides policy recommendations. 


\section{Labour Market Indicators 2000 to 2012: The Rise of Full-Time Employment}

\section{International Differences in Labour Force Participation Rates: The Asia Region}

Before we analyse the labour market in 2000-12 in more detail, we would like to provide a context for the longer period 1993-2012, focusing on Indonesia's performance and position in the Asia region. In the past 20 years, countries in Asia experienced very different developments in labour force participation rates (figure 1). Although labour force rates tend to change very slowly over time, ILO's labour data indicate that countries such as the Philippines, Thailand, and Japan saw moderate declines in labour force participation rates, whereas China, Indonesia, and Malaysia saw slight increases. Indonesia belongs to the group of countries that saw increases in labour force participation; it also belongs to those countries, including China, Thailand, and Vietnam, that have some of the highest labour force participation rates in Asia.

Figure 1: Labour Force Participation Trends in Asian Countries (1993-2012)

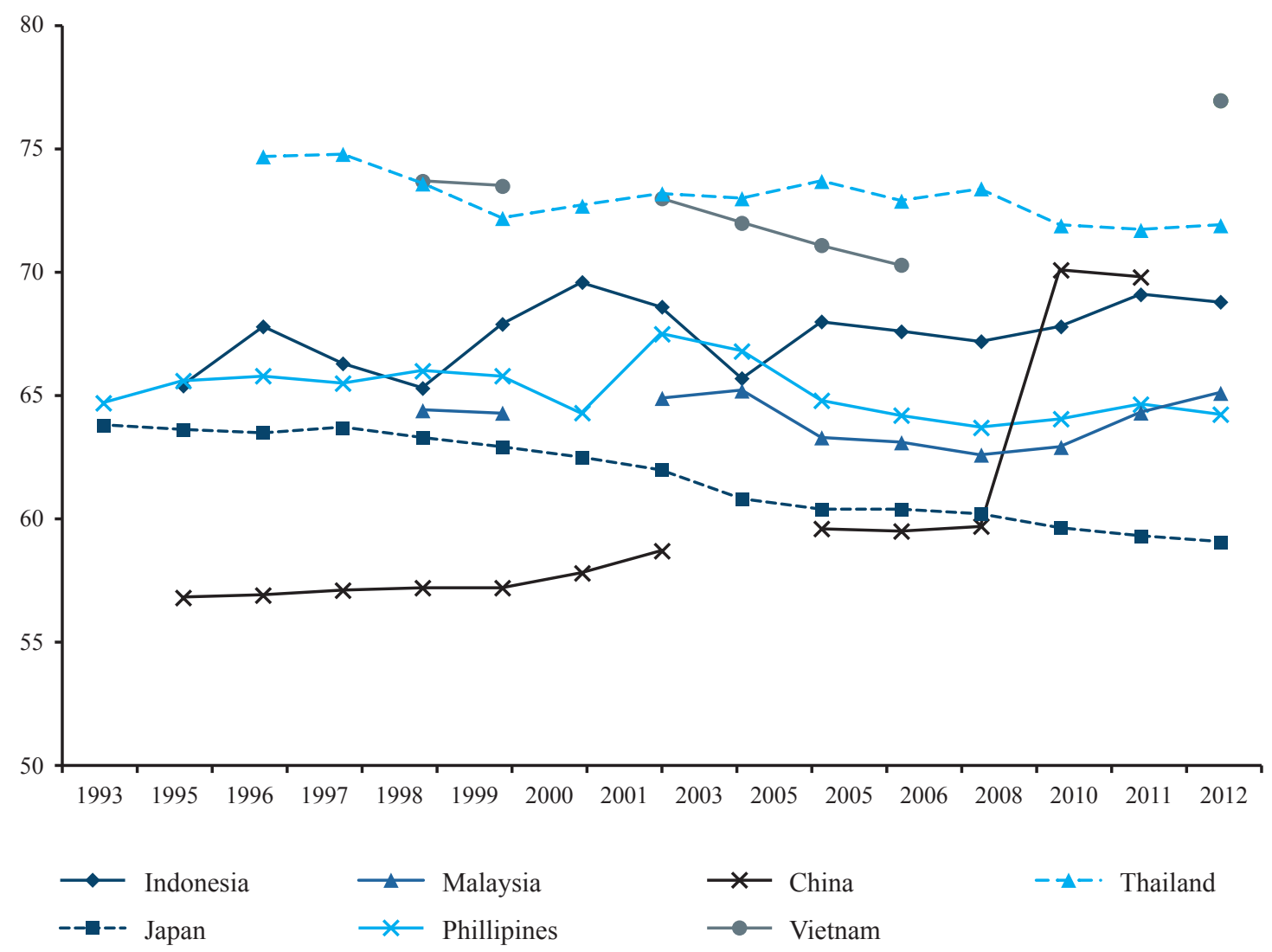

Note: For some countries, data are not available in every year. Participation rates for India are only available for the years 2004 (58.7\%) and 2010 (54.8\%). Statistics for Indonesia are identical with the official Statistics Indonesia estimates, which are based on Sakernas data. All statistics are taken from the ILO's Labour Statistics Databases (LABORSTA) and ILOSTAT databases. 


\section{Labour Force Participation, Full-Time Employment, and Underemployment}

\section{Strong Increases in Labour Force Participation Rate and Jobs with Full-Time Employment}

The trend of increasing labour force participation rates (LFPRs) in Indonesia, as well as the overall level of labour force participation, can be replicated with data from Susenas focusing on the period 2000-12. In line with the official Statistics Indonesia Sakernas data, Susenas shows that the growth in the LFPR has not occurred evenly throughout each year. After the turbulence of the economic and financial crisis of 1997/1998, economic growth recovered and poverty levels started falling again. However, economic growth and poverty reduction seem not to have been triggered by strong growth in jobs in the beginning of the 2000s; the World Bank called the time between 1999 and 2003 a period of jobless growth (World Bank 2010). As shown in figure 2, the LFPR increased slightly from $63.03 \%$ to $65.07 \%$ between 2000 and 2003 and, in line with Sakernas data, the LFPR decreased slightly in the wake of the fuel price cuts in 2005/6. Since 2006 the LFPR increased strongly, and from 2000 to 2012, the rate increased from $63.03 \%$ to $67.38 \%$. In absolute terms, the increase in the size of the labour force appears even more remarkable. In 2000 about 87 million Indonesians were active in the labour force, and by 2012, this number had increased to nearly 117.5 million, that is, more than 30 million additional persons are now participating in the labour market (table 1).

Figure 2: Trend in Labour Force Participation Rate (2000-12)

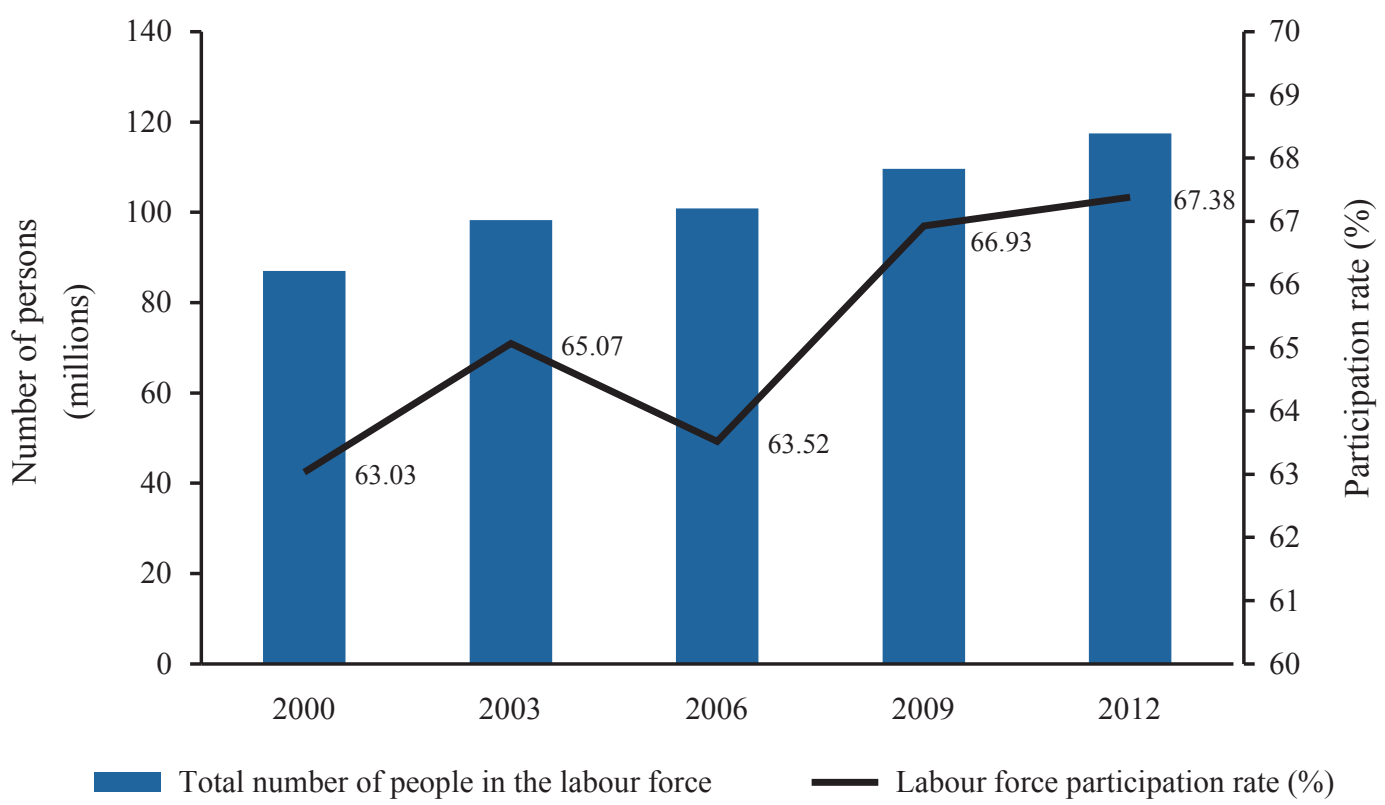

Note: TNP2K calculations based on Susenas rounds. Survey weights applied. 


\section{Box 1: Notes on Key Labour Market Indicators and Definitions*}

This paper uses the concepts of key labour market indicators universally applied by Statistics Indonesia (BPS 2013a). The definition of each indicator follows:

Labour force participation. Labour force refers to the working-age population who are economically active. Working-age individuals (ages 15 years and older) considered out of the labour force include people who do not actively engage in job searching, such as those who attend schools, take care of a household, or perform other activities. The 'labour force participation rate' indicates the size of the working-age population that is economically active. In other words, it shows the state of labour supply of a nation. The LFPR is measured as the percentage of total labour force to the total working-age population.

Employment. Working persons include individuals who perform economic activities continuously for at least one hour during the past week to obtain earnings or profits; economic activities here refer to either (1) working at a job or (2) having a job but not working for one of several reasons: annual leave, sickness, etc. Two subcategories exist under employment:

- Full-time employment. Full-time employees include individuals who work 35 or more hours a week.

- Underemployment. The underemployed include individuals who work 1 to 35 hours a week.

The employment rate refers to the share of employed individuals within the total labour force. The full-time employment rate is defined as the proportion of individuals who currently engage in fulltime employment to the total labour force. The underemployment rate is defined as the share of underemployed individuals to the total labour force.

Unemployment. Individuals in the labour force fall into the category of unemployed if they (1) are not working but are looking for work; (2) are not working but are preparing to start a business; (3) do not work and are unable to find a job because they gave up hope (also referred to as discouraged workers); (4) do not work but are not looking for work because they have already been accepted into employment but have not yet started working.

Formal and informal employment. In compliance with Statistics Indonesia classifications, the formal and informal sectors are defined by their main employment status. There are seven categories of employment status: (1) self-employed (own account worker); (2) self-employed assisted by temporary/ unpaid workers; (3) employer with permanent/paid workers; (4) employee; (5) casual employee in agriculture; (6) casual employee in nonagriculture; and (7) unpaid worker. Formal employment refers to an employer with permanent/paid workers and employees. Furthermore, salaried workers are those who work as employees (receiving a wage/salary) in cash or in-kind while non-salaried workers are those who are self-employed.

Real per capita expenditure decile. Real per capita expenditure is derived by adjusting nominal per capita expenditure using a spatial price deflator calculated from the rural and urban province-specific poverty lines in each respective year. Per capita expenditure is calculated by dividing overall household expenditure of those who belong to the working-age population by the number of household members. The real per capita expenditure decile is used to rank individuals in the working-age population, that is, an individual classified in decile 1 belongs to the poorest $10 \%$ and an individual classified in decile 10 belongs to the richest $10 \%$ of all households in Indonesia.

* The analysis in this report uses Susenas data. In contrast to Sakernas data, Susenas data do not permit differentiation between part-time employment and genuine underemployment (cases in which people would like to work more hours per week). Therefore, both, part-time and genuine underemployment is classified as underemployment in this report. 
The employment rate (the share of the total labour force consisting of working individuals) has been very high throughout all the years (figure 3). Of those individuals that constitute the labour force, nearly all of them state that they are working and only a small fraction claim to be unemployed. The share of persons actively looking for a job and not in any sort of employment (the unemployed ${ }^{3}$ ) has further decreased in recent years; in 2012 to $3.14 \%$ of the labour force was unemployed (table 1). According to Susenas, employment rates ranged between $95 \%-97 \%$ in $2000-12$, except for decreases in 2003-06 (figure 3). ${ }^{4}$

\section{Figure 3: Trend in the Employment Rate (2000-12)}

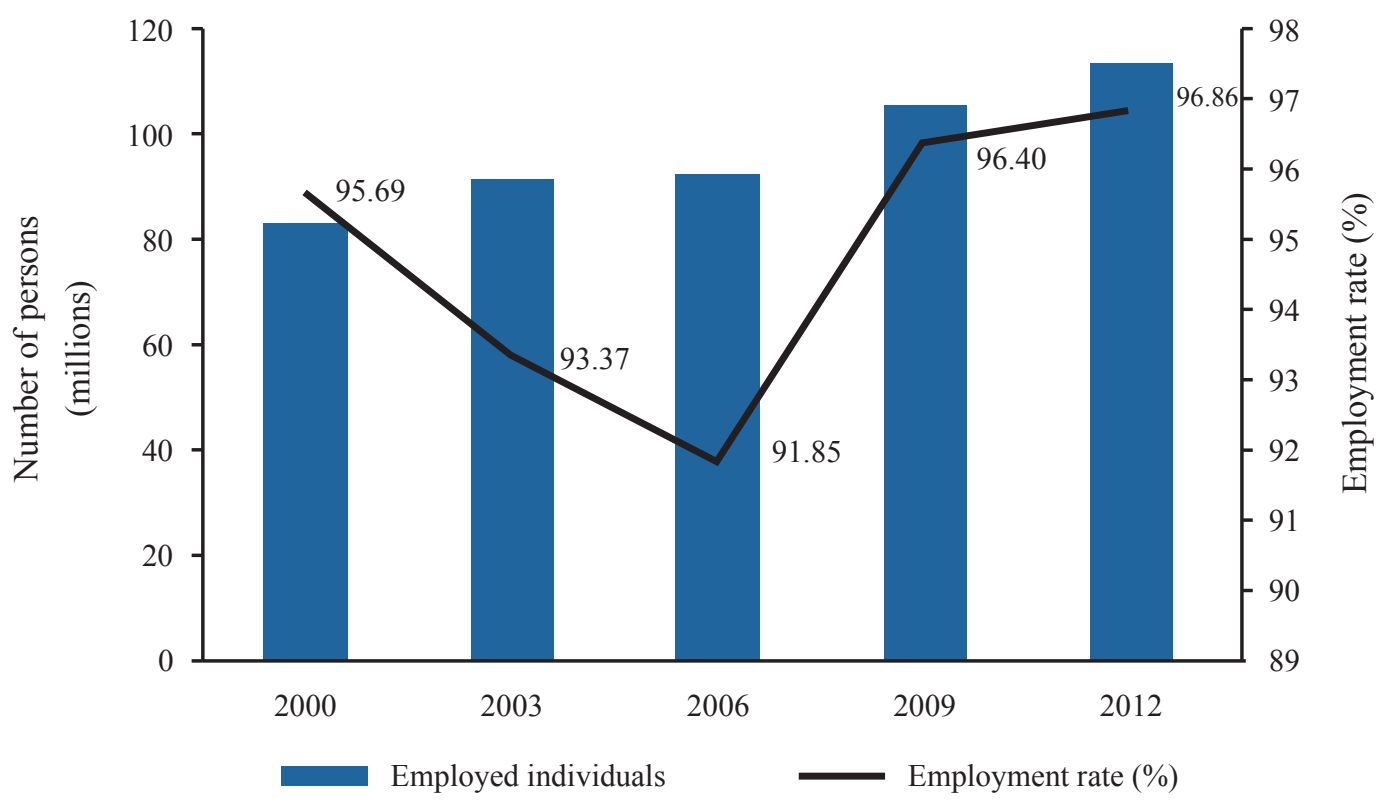

Note: TNP2K calculations based on Susenas rounds. Survey weights applied.

Not only has the number of jobs and persons employed increased since 2000, but more important, the number and share of jobs constituting full-time employment (at least 35 hours per week) has also risen continuously and sharply throughout this entire period. As shown in table 1, in 2000, about 58.68\% of individuals in the labour force engaged in full-time employment; by 2012 this share had risen to $68.06 \%$. Accordingly, the share of those classified as underemployed by Statistics Indonesia (at least 1 hour of work a week but less than 35 hours a week) has decreased from $37.01 \%$ in 2000 to $28.80 \%$ in 2012. These data are clearly positive and indicate that the potential to obtain sufficient income from work has increased in the past 12 years.

\footnotetext{
3 This report applies the current Statistics Indonesia definition of unemployment to all years analysed. Please see Suryadarma et al. (2007) for a more comprehensive overview on the history of unemployment measurement by Statistics Indonesia in Indonesia.

4 Alisjahbana and Manning (2006), using the 2002 Susenas round, found that being unemployed is not associated with being poor. Unemployment rates derived from Sakernas are slightly higher than those obtained from Susenas are but remain comparable (ILO 2013).

5 In line with its 'decent work' concept, the ILO further differentiates between full-time employment and employment with excessive working hours. Because this report follows the Statistics Indonesia definition, we do not provide separate estimates for excessive working hours.
} 
Table 1: Employment Trends (2000-12)

\begin{tabular}{|lccccc|}
\hline \multicolumn{1}{c}{$\begin{array}{c}\text { Labour Market } \\
\text { Indicators }\end{array}$} & $\mathbf{2 0 0 0}$ & $\mathbf{2 0 0 3}$ & $\mathbf{2 0 0 6}$ & $\mathbf{2 0 0 9}$ & $\mathbf{2 0 1 2}$ \\
\hline Total working-age population & $138,106,153$ & $150,988,614$ & $158,766,431$ & $163,787,957$ & $174,333,612$ \\
\hline Total labour force & $87,041,675$ & $98,248,688$ & $100,850,392$ & $109,630,216$ & $117,467,232$ \\
\hline Employment rate (\%) & 95.69 & 93.37 & 91.85 & 96.40 & 96.86 \\
\hline $\begin{array}{l}\text { Full-time employment rate } \\
\text { (\%) }\end{array}$ & 58.68 & 62.20 & 61.18 & 63.26 & 68.06 \\
\hline Underemployment rate (\%) & 37.01 & 31.17 & 30.67 & 33.14 & 28.80 \\
\hline Unemployment rate (\%) & 4.31 & 6.63 & 8.15 & 3.60 & 3.14 \\
\hline
\end{tabular}

Note: TNP2K calculations based on Susenas rounds. Survey weights applied.

\section{The Urban Labour Market as a Driver of Job Creation}

Indonesia is the world's largest archipelago and comprises complex and diverse cultural, linguistic, and geographic settings. As a consequence, Indonesia has no one unified labour market but many local labour markets, each with its particular set of jobs (supply side) and human resources (demand side) available. Categories of local labour markets are often distinguishable along a rural/urban divide; among provinces; between Java island and off-Java areas; and even between the two regions of Western Indonesia and Eastern Indonesia. We will focus our discussion here on the rural-urban divide.

As shown in figure 4 and table 2, notable differences exist between rural and urban labour markets in Indonesia. Rural labour markets are generally characterised by higher labour force participation rates than urban labour markets are. However, urban labour markets are more likely to provide jobs with fulltime employment compared with rural labour markets. Moreover, although unemployment is nearly nonexistent in rural labour markets, urban labour markets show relatively high rates of unemployment. However, the nature of and reasons behind urban unemployment rates are likely to be very different from rural unemployment rates; urban unemployment rates capture a large number of persons who are temporarily unemployed because they have recently finished their education, a substantial number of arriving new migrants looking for jobs, and many people who are in the process of changing jobs.

Between 2000 and 2012, the LPFR increased in both rural and urban labour markets. However, although the rate in rural areas increased only slightly from $67.41 \%$ in 2000 to $69.65 \%$ in 2012 , the rate in urban areas increased sharply from $57.34 \%$ in 2000 to $65.14 \%$ in 2012 , approaching the rural LFPR. In absolute terms the number of persons in the urban labour market increased from about 34.5 million in 2000 to more than 57 million in 2012 (table 2). The positive trend in the job market is reinforced by the share of jobs that provide full-time employment. In both rural and urban labour markets, the share of jobs that provide full-time employment has steadily increased throughout the period. 
Figure 4: Labour Force Participation by Rural and Urban Area (2000-12)

Urban

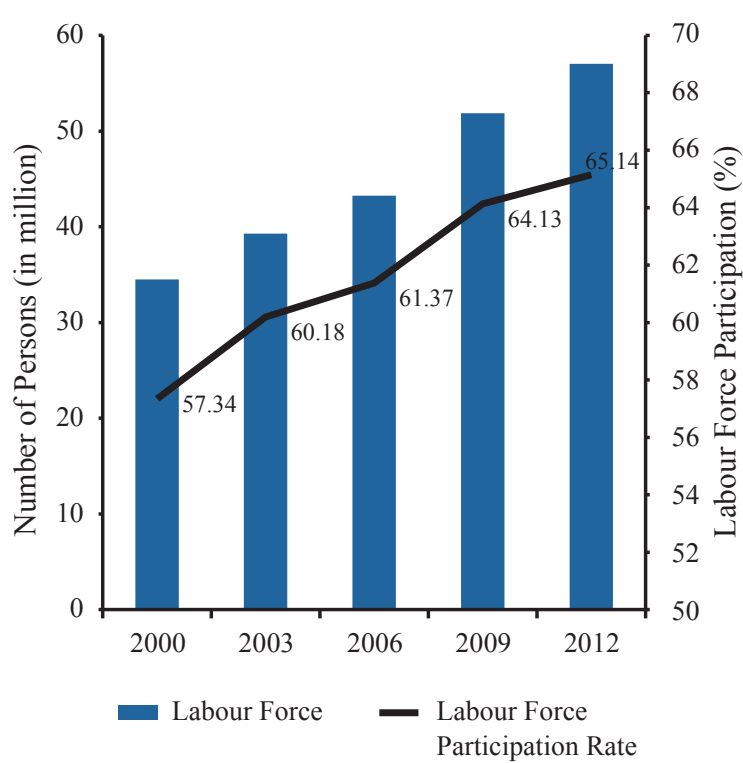

Rural

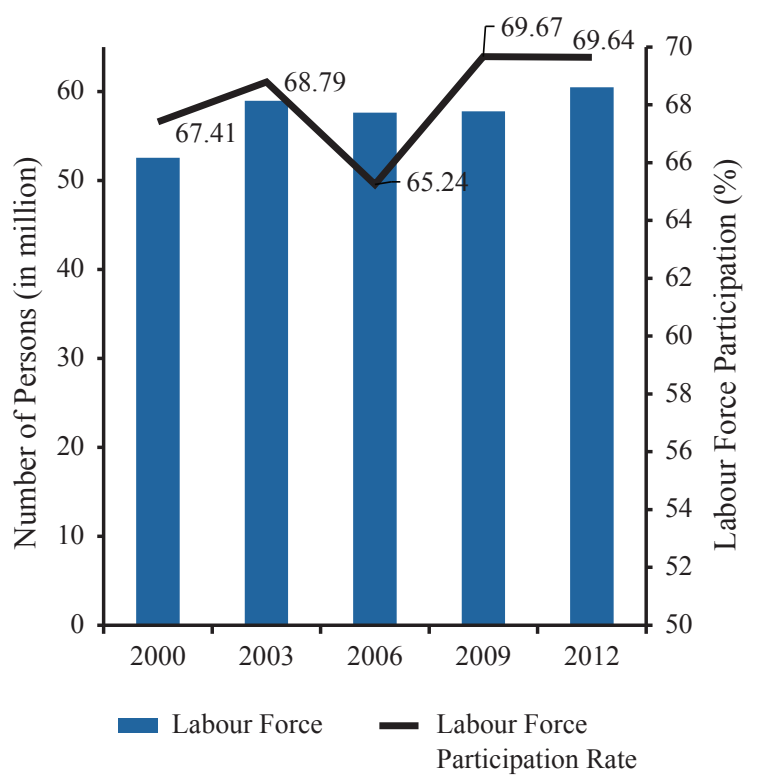

Note: TNP2K calculations based on Susenas rounds. Survey weights applied.

Table 2: Employment Rates by Area (Selected Years)

\begin{tabular}{|lccccc}
\hline Labour Market Indicators & $\mathbf{2 0 0 0}$ & $\mathbf{2 0 0 3}$ & $\mathbf{2 0 0 6}$ & $\mathbf{2 0 0 9}$ & $\mathbf{2 0 1 0}$ \\
\hline Urban & & & & & \\
Labour force participation (\%) & 57.34 & 60.18 & 61.37 & 64.13 & 65.14 \\
\hline Employment (\%) & 93.01 & 89.99 & 89.14 & 94.96 & 95.97 \\
\hline Full-time employment (\%) & 71.88 & 71.86 & 71.17 & 71.73 & 76.58 \\
\hline Underemployment (\%) & 21.13 & 18.13 & 17.97 & 23.23 & 19.39 \\
\hline Unemployment (\%) & 6.99 & 10.01 & 10.86 & 5.04 & 4.03 \\
\hline Total labour force & $34,495,645$ & $39,288,021$ & $43,250,259$ & $51,857,404$ & $57,007,494$ \\
\hline Total working-age population & $60,160,535$ & $65,279,404$ & $70,470,097$ & $80,861,723$ & $87,510,912$ \\
Rural & & & & 612 & 69.64 \\
\hline Labour force participation (\%) & 67.41 & 68.79 & 65.24 & 69.67 & 97.70 \\
\hline Employment (\%) & 97.45 & 95.62 & 93.88 & 97.70 & 60.03 \\
\hline Full-time employment (\%) & 50.01 & 55.76 & 53.68 & 55.66 & 37.67 \\
\hline Underemployment (\%) & 47.44 & 39.85 & 40.20 & 42.05 & 2.30 \\
\hline Unemployment (\%) & 2.55 & 4.38 & 6.12 & 2.30 & $60,459,745$ \\
\hline Total labour force & $52,546,030$ & $58,960,666$ & $57,600,134$ & $57,772,811$ \\
\hline Total working-age population & $77,945,618$ & $85,709,210$ & $88,296,334$ & $82,926,234$ & $86,822,700$ \\
\hline (\%o: & & & & \\
\hline
\end{tabular}

Note: TNP2K calculations based on Susenas rounds. Survey weights applied. 


\section{Gender Differences in LFPR and Patterns of Full-Time Employment}

As widely documented in labour market literature, job markets and employment opportunities are usually very different for men and women. The reasons behind these differences are diverse and often related to prevailing sociocultural norms (fertility, care giving, household management, etc.) as well as gender-specific preference and skill sets. Likewise, labour market discrimination against women may contribute to overall labour market outcomes, although the existence, extent, and type of discrimination are hard to assess using existing data in Indonesia.

Throughout the entire reference period discussed here, the LFPR among men has significantly surpassed that of women; both men and women have shown increases in the LFPR between 2000 and 2012 (figure 5 and table 3). Although in $2000,81.19 \%$ of men in the working-age population were part of the labour force, their share increased to $84.56 \%$ in 2012 . The LFPR among women saw an even stronger increase: women's LFPR increased by about 5 percentage points from $45.26 \%$ in 2000 to $50.27 \%$ in 2012 .

Two other features of the gender-specific labour market in Indonesia are noteworthy:

First and similar to OECD countries (World Bank 2013; OECD 2013), strong differences exist between men and women in their shares of underemployment and full-time employment: a greater proportion of women are employed part-time. This high share is often related to women's greater responsibility for domestic work and child raising and the difficulties women face in re-entering the formal labour market after raising their children.

It is important to note that, in 2000, women who were working were equally likely to be underemployed (48.54\%) as employed full-time (46.89\%), whereas men in about two-thirds $(65.39 \%)$ of all cases were employed full-time (table 3). In 2012 the share of women in full-time positions increased significantly to $58.63 \%$ and the share of men in full-time positions increased to $73.69 \%$.

Second, unemployment in the early 2000s was more pronounced among women; however, by 2006 unemployment rates among both men and women were about $3 \%$ (table 3 ). The higher unemployment rate among women in the early 2000s aligned with findings of studies from the academic literature (e.g., Smith et al. 2002) showed that, in the aftermath of the 1997/1998 financial crisis, many more women were drawn into the labour force in order to compensate for the falling real wages of men. Most likely, not all of these women were able to find employment during and in the immediate years after the crisis. 
Figure 5: Labour Force Participation by Gender (2000-12)

Male

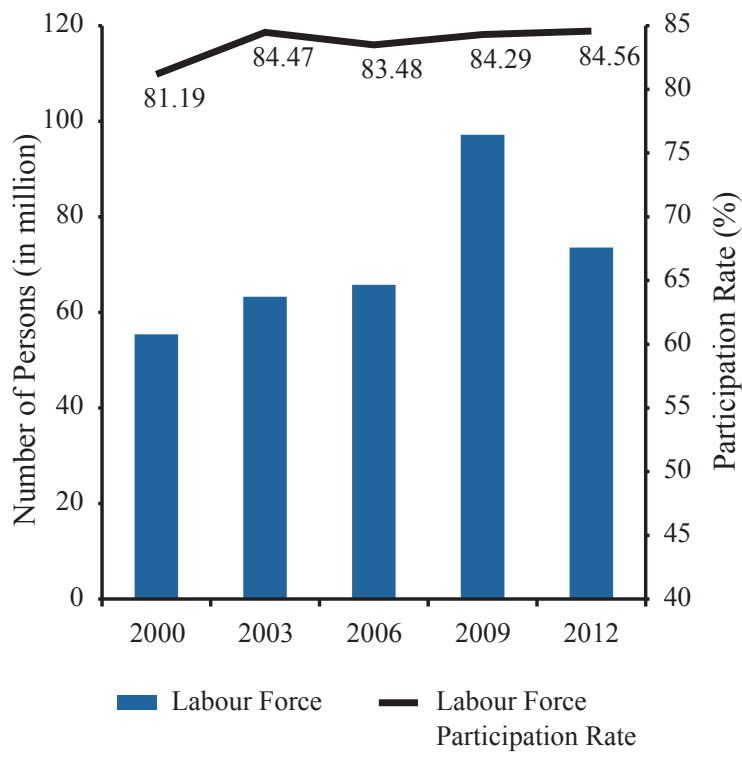

Female

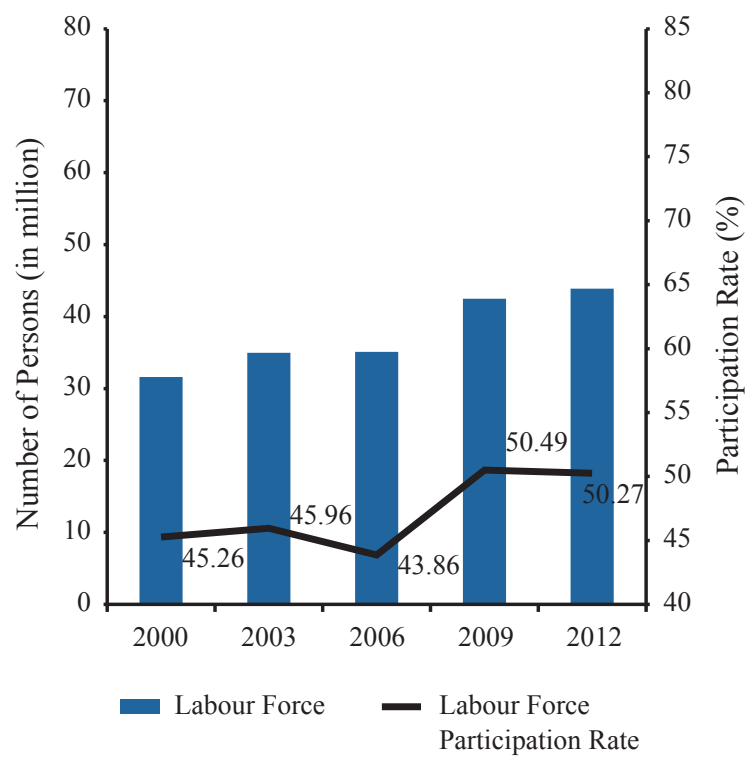

Note: TNP2K calculations based on Susenas rounds. Survey weights applied.

Table 3: Employment Rates by Gender (2000-12)

\begin{tabular}{|c|c|c|c|c|c|}
\hline $\begin{array}{l}\text { Labour Market } \\
\text { Indicators }\end{array}$ & 2000 & 2003 & 2006 & 2009 & 2010 \\
\hline \multicolumn{6}{|l|}{ Female } \\
\hline $\begin{array}{l}\text { Labour force participation } \\
(\%)\end{array}$ & 45.26 & 45.96 & 43.86 & 50.49 & 50.27 \\
\hline Employment (\%) & 95.44 & 91.12 & 89.27 & 96.02 & 96.87 \\
\hline Full-time employment (\%) & 46.89 & 48.65 & 49.84 & 53.03 & 58.63 \\
\hline Underemployment (\%) & 48.54 & 42.47 & 39.43 & 43.00 & 38.23 \\
\hline Unemployment (\%) & 4.56 & 8.88 & 10.73 & 3.98 & 3.13 \\
\hline Total labour force & $31,609,606$ & $34,962,228$ & $35,080,404$ & $42,462,472$ & $43,897,066$ \\
\hline Total working-age population & $69,834,352$ & $76,066,439$ & $79,979,110$ & $84,098,878$ & $87,329,941$ \\
\hline \multicolumn{6}{|l|}{ Male } \\
\hline $\begin{array}{l}\text { Labour force participation } \\
(\%)\end{array}$ & 81.19 & 84.47 & 83.48 & 84.29 & 84.56 \\
\hline Employment (\%) & 95.83 & 94.61 & 93.22 & 96.65 & 96.86 \\
\hline Full-time employment (\%) & 65.39 & 69.69 & 67.23 & 69.73 & 73.69 \\
\hline Underemployment (\%) & 30.44 & 24.92 & 26.00 & 26.92 & 23.17 \\
\hline Unemployment (\%) & 4.17 & 5.39 & 6.78 & 3.35 & 3.14 \\
\hline Total labour force & $55,432,069$ & $63,286,459$ & $65,769,989$ & $67,167,743$ & $73,570,173$ \\
\hline Total working-age population & $68,271,801$ & $74,922,175$ & $78,787,321$ & $79,689,079$ & $87,003,671$ \\
\hline
\end{tabular}

Note: TNP2K calculations based on Susenas rounds. Survey weights applied. 
For a comprehensive understanding of the labour market, it is important to see, not only how labour force participation rates have changed over time (extensive margin) but also how many hours, days, and weeks a person works in a job (intensive margin). As described above, there has been a significant shift away from underemployment towards full-time employment. This shift is reflected in the number of hours a person on average reports to work in a week.

Figure 6 and table 4 depict changes over time in the number of hours worked per week and the number of days worked during a week, conditional on having a job. As shown in figure 6, Indonesians in 2012 are working on average longer hours per week (41.11 hours in 2012 compared with 37.74 hours in 2000) and slightly more days (5.89 days in 2012 compared with 5.75 days in 2000). The same holds true for urban and rural areas as well as for male and female employment (table 4). Although workers in urban areas work more hours per week on average (44.87 hours a week in 2012) than workers in rural areas (37.58 hours a week in 2012), employment trends in both areas indicate rises in hours worked per week compared with 2000.

Likewise, in 2000, men who were working spent about 39.92 hours per week on average in their jobs while women who were working spent about 33.90 hours per week on average in their job. In the past 12 years, one can observe significant increases in the number of hours worked by women ( 37.85 hours a week in 2012), while the gap between men and women in the numbers of hours worked narrowed despite men's working hours also increasing to an average of 43.05 hours a week in 2012. In general, one can say that men are more likely to actively participate in the labour market and, once working, they are more likely to work longer hours than women are. However, these circumstances are changing as women's LPFRs and number of hours worked have increased at faster rates than those of men in the same period.

In general, it seems that, from 2000 to 2012 , economic growth has been accompanied by positive developments in the labour market. 


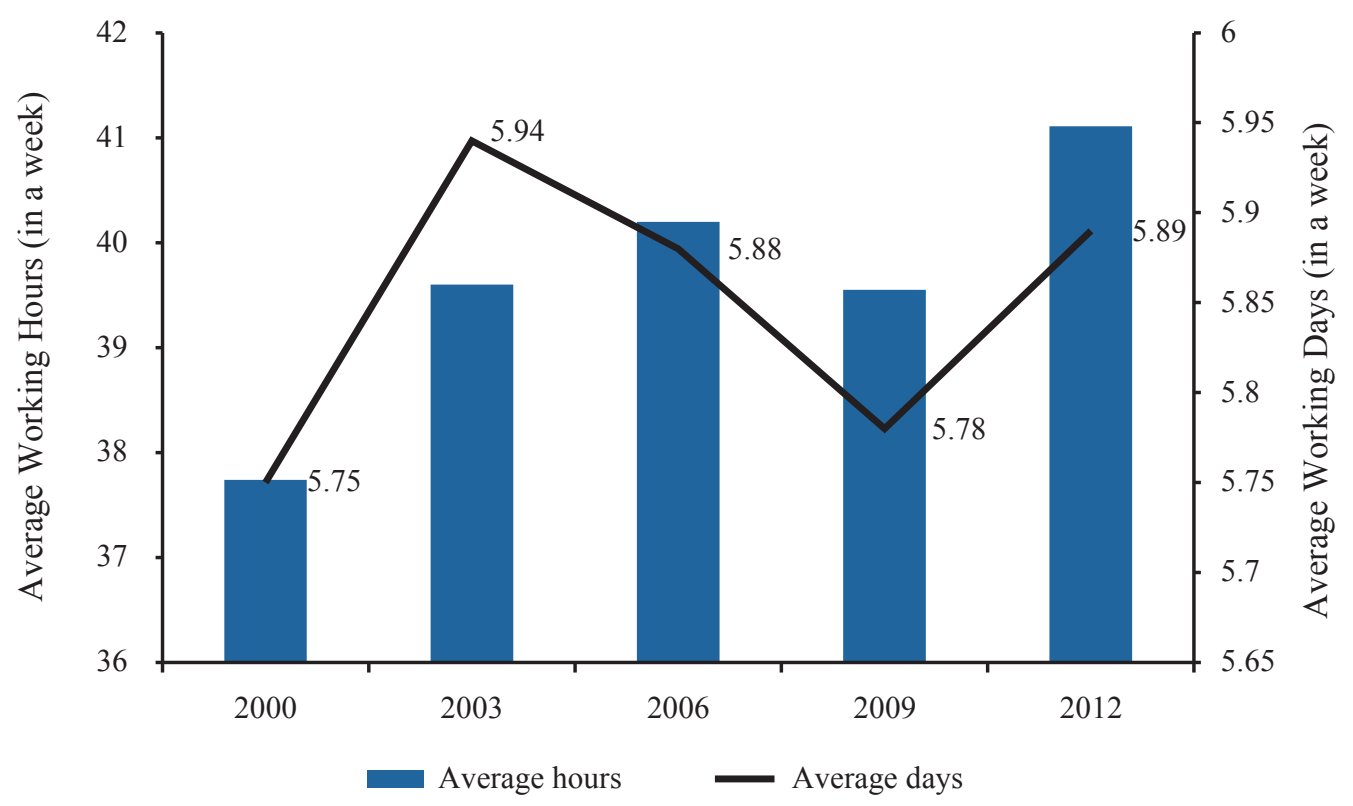

Note: TNP2K calculations based on Susenas rounds. Survey weights applied. Statistics are conditional on having a job/working.

Table 4: Length of Work by Gender and Area

\begin{tabular}{|lccccc|}
\hline \multicolumn{1}{c}{ Length of Work } & $\mathbf{2 0 0 0}$ & $\mathbf{2 0 0 3}$ & $\mathbf{2 0 0 6}$ & $\mathbf{2 0 0 9}$ & $\mathbf{2 0 1 2}$ \\
\hline Working days Overall & 5.75 & 5.94 & 5.88 & 5.78 & 5.89 \\
\hline Urban & 5.95 & 6.02 & 6.01 & 5.89 & 5.98 \\
\hline Rural & 5.62 & 5.89 & 5.78 & 5.67 & 5.80 \\
\hline Male & 5.82 & 6.03 & 5.94 & 5.84 & 5.93 \\
\hline Female & 5.62 & 5.77 & 5.76 & 5.67 & 5.83 \\
\hline Working hours Overall & 37.74 & 39.60 & 40.20 & 39.55 & 41.11 \\
\hline Urban & 43.70 & 44.36 & 45.40 & 43.51 & 44.87 \\
\hline Rural & 34.00 & 36.63 & 36.49 & 36.09 & 37.58 \\
\hline Male & 39.92 & 41.79 & 41.89 & 41.72 & 43.05 \\
\hline Female & 33.90 & 35.50 & 36.88 & 36.09 & 37.85 \\
\hline
\end{tabular}

Note: TNP2K calculations based on Susenas rounds. Survey weights applied.

Statistics are conditional on having a job/working. 


\section{Labour Market Differences among the Working Poor vs. the Working Nonpoor}

\section{Labour Force Participation across the Wealth Distribution}

In recent years, a better understanding of the relationship between labour markets and poverty has emerged: persons are not necessarily poor because they do not find employment but rather because the employment they find does not provide enough working time (hours of work) or adequate income or hourly wages. Although Susenas does not allow for an investigation of the latter issue, it does allow for analysis of levels and trends in LFPRs and hours worked across the wealth distribution.

The following analysis classifies all individuals in the working-age population (age 15 years and older) into real expenditure per capita deciles by dividing overall household expenditures by the number of household members and then using a spatial price deflator to adjust for living cost differences. ${ }^{6} \mathrm{~A}$ person that is classified within decile 1 is a member of a household that belongs to the poorest $10 \%$ of households in Indonesia, whereas an individual in decile 10 belongs to a household that is in the richest $10 \%$ of households in Indonesia. In 2000, Statistics Indonesia classified the bottom 20\% of households as poor, while in 2012 about $10 \%$ of households were classified as poor. Focusing on individuals in the bottom $10 \%$ keeps track of those individuals who are the poorest in the country in the reference period and who are still classified as poor in 2012.

As shown in table 5 and figures 7 and 8 , the differences in the LFPR across wealth deciles is rather small: in 2012 the LFPR in decile 1 was about $65 \%$ and in the richest decile about $67 \%$. It becomes clear therefore that the poor are not poor because of insufficient attachment to the labour market and other factors determine whether somebody is poor. However, although the gap of 2 percentage points between workers in the poorest and richest deciles appears small, there seems to be a stronger trend towards higher LFPRs across richer deciles. In fact, as shown in table 5 and figure 7, LFPRs in 2000 were actually highest in the poorest deciles, although between 2000 and 2012, this pattern has slightly reversed. Although labour force participation has increased with time in the poorest decile, it has increased much more strongly among the richer deciles ${ }^{7}$.

\footnotetext{
6 The ratio of Statistics Indonesia's rural and urban province-specific poverty lines (referenced to Jakarta) for the respective years were used to derive the spatial price deflator. We abstained from directly applying Statistics Indonesia poverty lines to classify individuals into poor and nonpoor, since it is impossible for researchers to accurately reproduce official poverty rates for the early years (before 2009), with the available Susenas data and the published official poverty lines.

7 It should be noted that the trend in the labour force participation rate across the wealth distribution is highly sensitive to whether nominal or real expenditure per capita is used. Relying on nominal expenditure per capita, Purnagunawan and Firmana (2013) and ILO (2013) show that labour force participation rates are higher among the poorer deciles compared with richer deciles. However, in line with conventional welfare analysis and Statistics Indonesia practice to account for regional price differences by using regional poverty lines, it seems convincing that real expenditures per capita is the more suitable choice. Please see Priebe (2014) for a detailed overview on official poverty measurement in Indonesia.
} 
Table 5: Labour Force Indicators by Deciles (2000-12)

\begin{tabular}{|c|c|c|c|c|c|}
\hline Labour Force Indicators & 2000 & 2003 & 2006 & 2009 & 2012 \\
\hline \multicolumn{6}{|l|}{ Decile 1} \\
\hline Labour force (millions) & 7.68 & 8.75 & 8.86 & 9.59 & 10.28 \\
\hline Labour force participation rate $(\%)$ & 63.33 & 65.47 & 62.93 & 66.86 & 65.17 \\
\hline \multicolumn{6}{|l|}{ Decile 4} \\
\hline Labour force (millions) & 8.47 & 9.61 & 9.86 & 10.80 & 11.45 \\
\hline Labour force participation rate $(\%)$ & 63.92 & 66.12 & 64.18 & 67.80 & 67.40 \\
\hline \multicolumn{6}{|l|}{ Decile 7} \\
\hline Labour force (millions) & 8.87 & 10.08 & 10.40 & 11.27 & 12.06 \\
\hline Labour force participation rate $(\%)$ & 62.77 & 65.25 & 63.87 & 67.12 & 67.75 \\
\hline \multicolumn{6}{|l|}{ Decile 10} \\
\hline Labour force (millions) & 9.70 & 10.91 & 11.10 & 12.15 & 12.85 \\
\hline Labour force participation rate $(\%)$ & 60.47 & 62.79 & 62.16 & 65.87 & 67.30 \\
\hline \multicolumn{6}{|l|}{ Average (all deciles) } \\
\hline Labour force (millions) & 87.04 & 98.25 & 100.85 & 109.63 & 117.47 \\
\hline Labour force participation rate $(\%)$ & 63.03 & 65.07 & 63.52 & 66.93 & 67.38 \\
\hline
\end{tabular}

Source: TNP2K calculations based on Susenas rounds. Survey weights applied.

Figure 7: Labour Force Participation by Real per Capita Expenditure Decile (2012)

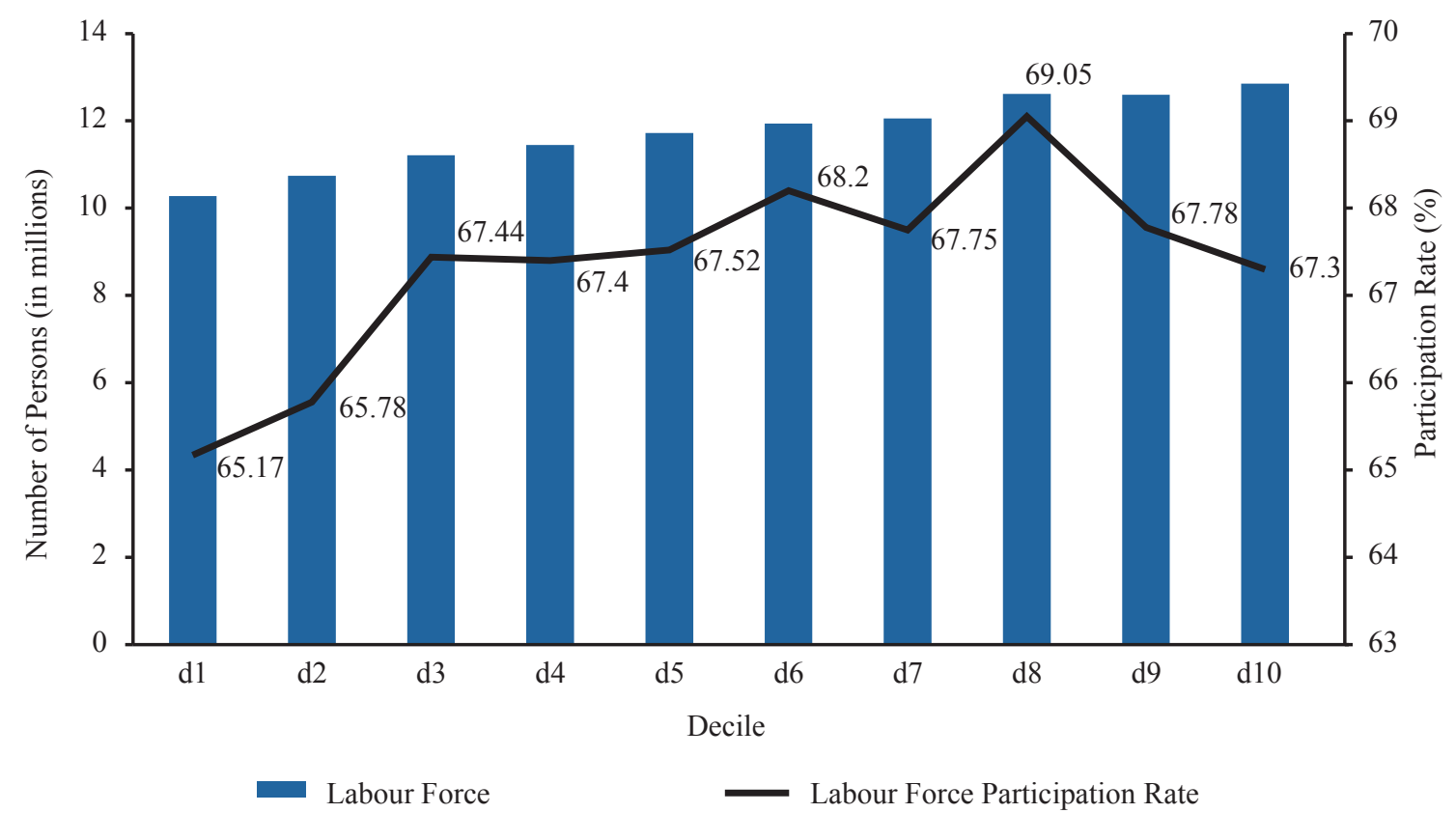

Note: TNP2K calculations based on Susenas rounds. Survey weights applied. 
Figure 8: Trend in Labour Force Participation (Selected Deciles)

The Bottom $10 \%$

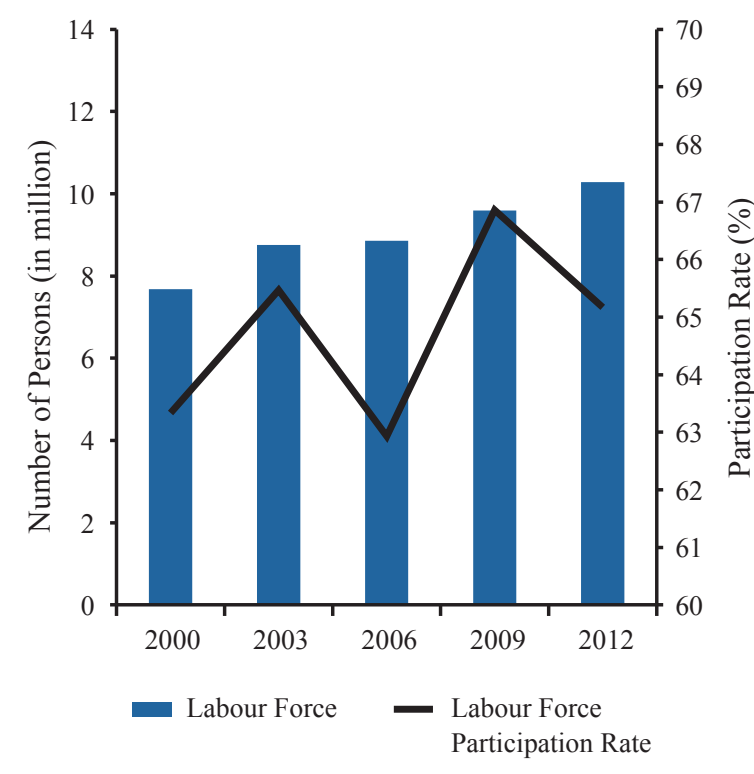

The Top $10 \%$

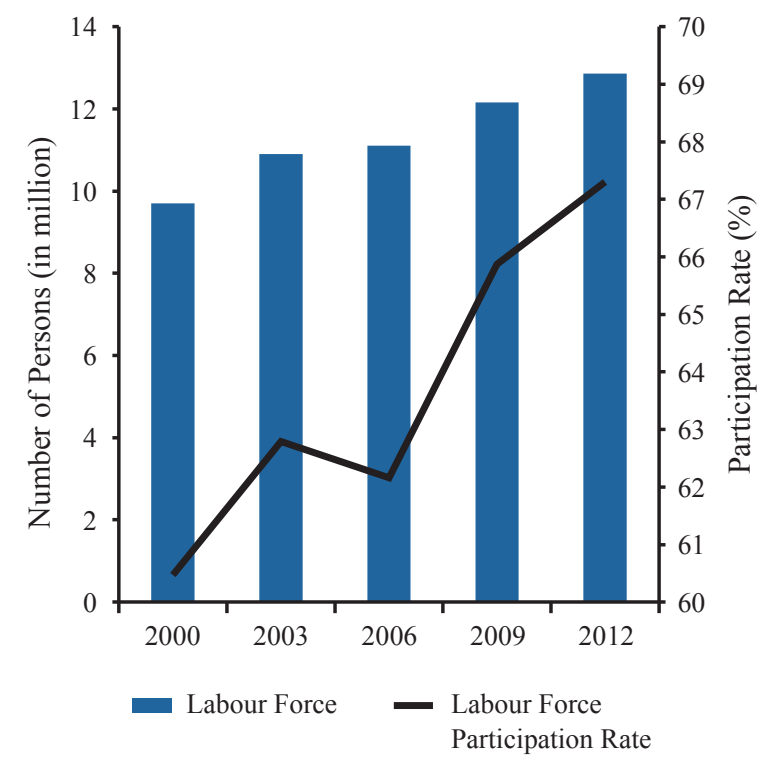

The Fourth Decile

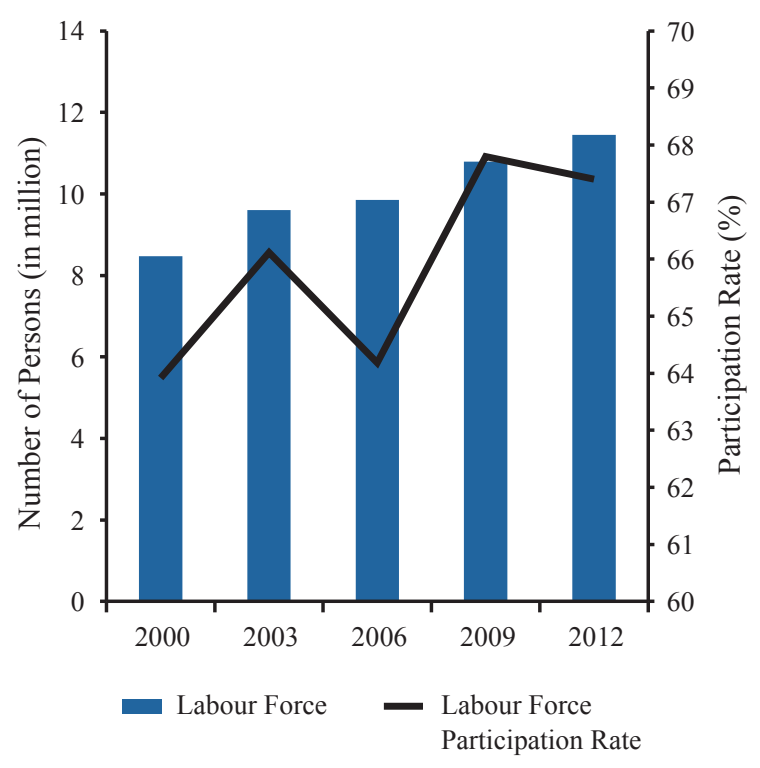

The Seventh Decile

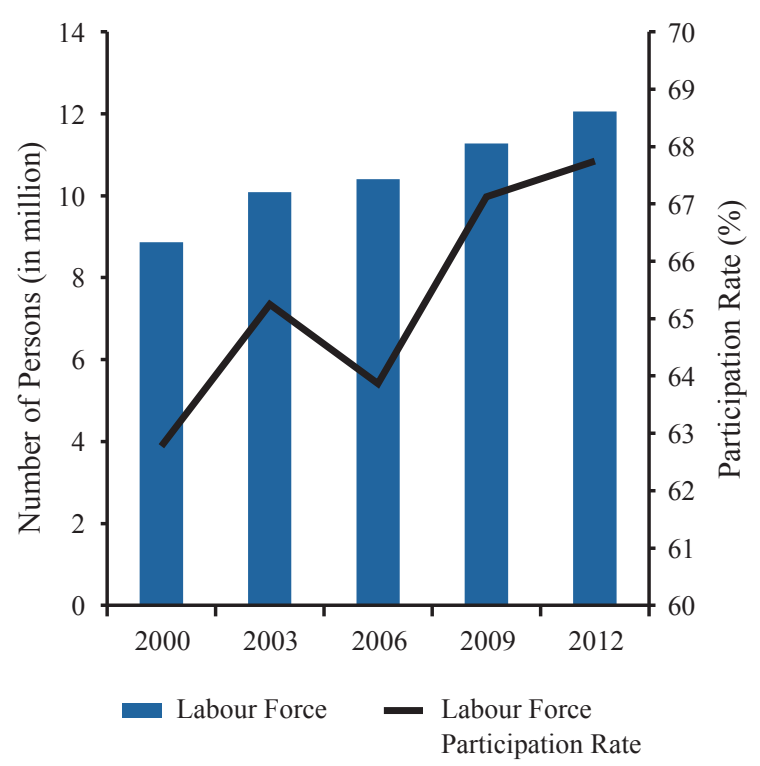

Note: TNP2K calculations based on Susenas rounds. Survey weights applied.

\section{Working Hours across the Wealth Distribution}

Although only small differences exist in LFPRs among the poor and better-off individuals, important differences exist in the number of hours worked in a job. As shown by table 6 and figures 9 and 10, individuals in decile 1 are less likely to work full-time and are more often underemployed than workers in richer deciles. This pattern seems to have become stronger over time. Although full-time employment has increased across all wealth deciles, the increase has been particularly strong among wealthier deciles. Therefore, underemployment is much more strongly associated with poverty now than it was 
in 2000. Although insufficient hours of work seem to be an important contributing factor of being poor, it is important to note that an increasing share of the working poor comprise persons who are in fulltime employment. Therefore, insufficient income and wages among the working poor play an important additional role in determining whether a person who works is poor or not.

Table 6: Employment Status (Selected Years)

\begin{tabular}{|c|c|c|c|c|c|}
\hline Employment Status & $\begin{array}{c}2000 \\
(\%)\end{array}$ & $\begin{array}{c}2003 \\
(\%)\end{array}$ & $\begin{array}{c}2006 \\
(\%)\end{array}$ & $\begin{array}{c}2009 \\
(\%)\end{array}$ & $\begin{array}{c}2012 \\
(\%)\end{array}$ \\
\hline Decile 1 Full-time employment & 52.16 & 54.33 & 52.34 & 54.47 & 58.09 \\
\hline Underemployment & 43.34 & 38.08 & 37.57 & 41.70 & 37.73 \\
\hline Unemployment & 4.50 & 7.59 & 10.10 & 3.84 & 4.18 \\
\hline \multicolumn{6}{|l|}{ Decile 4} \\
\hline Full-time employment & 55.54 & 59.38 & 57.14 & 60.05 & 65.04 \\
\hline Underemployment & 39.96 & 33.82 & 34.58 & 36.02 & 31.21 \\
\hline Unemployment & 4.50 & 6.80 & 8.28 & 3.93 & 3.76 \\
\hline \multicolumn{6}{|l|}{ Decile 7} \\
\hline Full-time employment & 59.23 & 63.26 & 62.19 & 64.79 & 70.41 \\
\hline Underemployment & 36.46 & 29.63 & 29.89 & 31.90 & 26.68 \\
\hline Unemployment & 4.31 & 7.10 & 7.91 & 3.31 & 2.91 \\
\hline \multicolumn{6}{|l|}{ Decile 10} \\
\hline Full-time employment & 69.40 & 72.44 & 73.79 & 74.06 & 79.27 \\
\hline Underemployment & 26.76 & 21.97 & 19.76 & 23.22 & 18.70 \\
\hline Unemployment & 3.84 & 5.58 & 6.45 & 2.73 & 2.03 \\
\hline \multicolumn{6}{|l|}{ Average (all deciles) } \\
\hline Full-time employment & 58.68 & 62.20 & 61.18 & 63.26 & 68.06 \\
\hline Underemployment & 37.01 & 31.17 & 30.67 & 33.14 & 28.80 \\
\hline Unemployment & 4.31 & 6.63 & 8.15 & 3.60 & 3.14 \\
\hline
\end{tabular}

Note: TNP2K calculations based on Susenas rounds. Survey weights applied. 
Figure 9: Employment Status by Real per Capita Expenditure (2012)

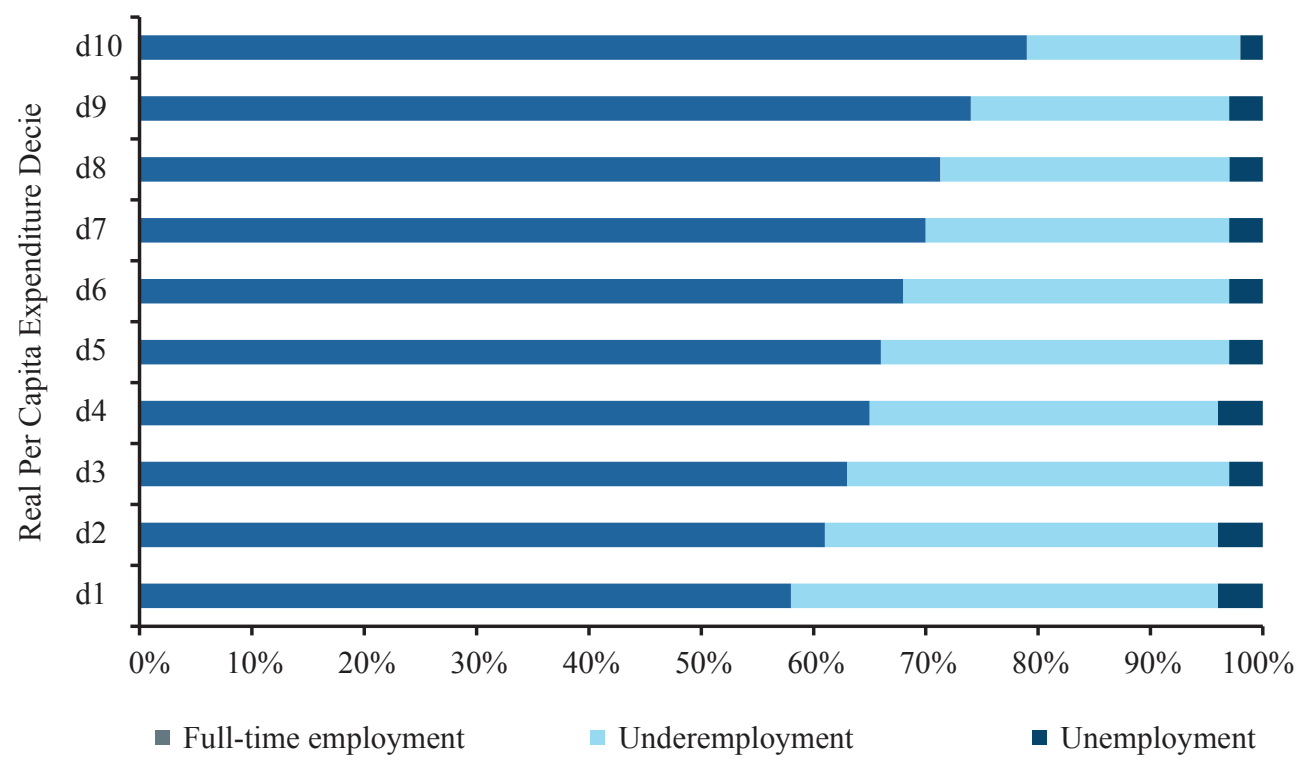

Note: TNP2K calculations based on Susenas rounds. Survey weights applied.

Figure 10: Length of Work by Real per Capita Expenditure (2012)

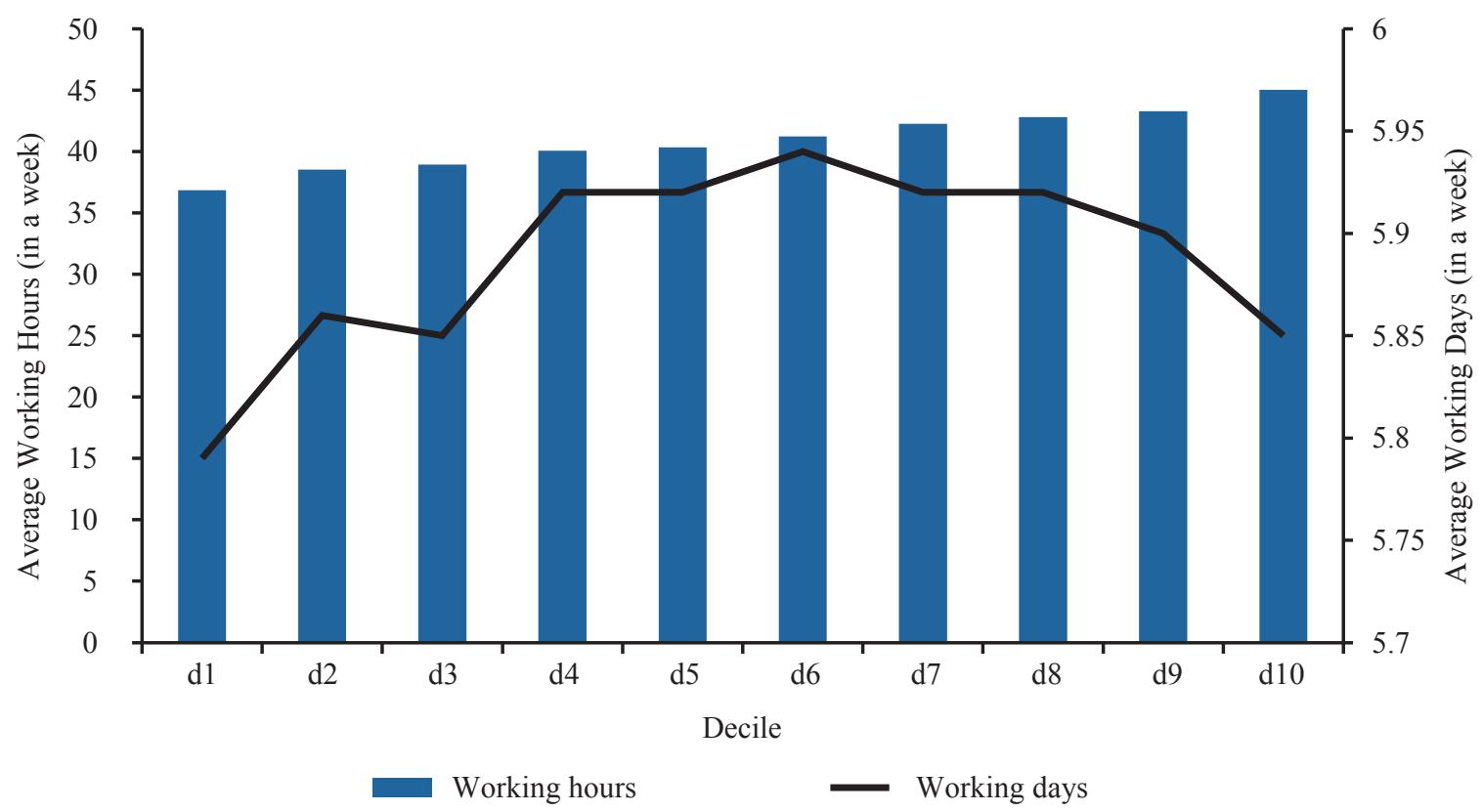

Note: TNP2K calculations based on Susenas rounds. Survey weights applied.

In addition to distinguishing between underemployment and full-time employment, it is worth analysing in more detail the number of hours and days worked across the wealth distribution (figure 11 and table 7). In line with the results above, the poor on average work fewer hours a week than the nonpoor do. In 2012 workers in the poorest decile worked on average about 37 hours (5.79 days) a week; whereas workers in the richest decile worked about 45 hours (5.85 days) a week. The differences in working 
hours across the wealth distribution point to fundamental differences in the types of employment and jobs of the working poor compared with the working nonpoor. The pattern of the working poor to work fewer hours a week than the nonpoor is robust through all selected years.

Figure 11: Length of Work (Selected Years)

Average Working Hours (2000-2012)

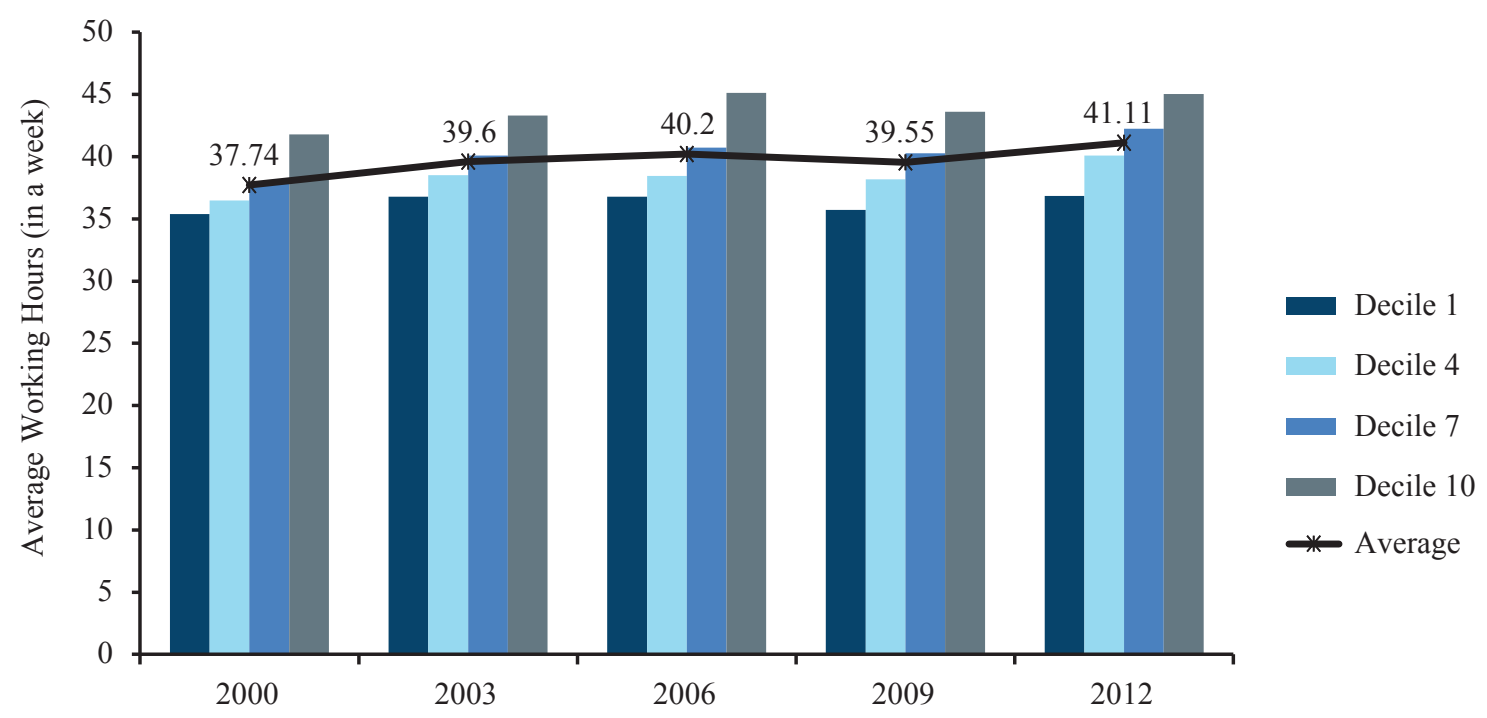

Note: TNP2K calculations based on Susenas rounds. Survey weights applied.

Table 7: Length of Work (Selected Years)

\begin{tabular}{lccccc}
\multicolumn{1}{l}{ Length of Work } & $\mathbf{2 0 0 0}$ & $\mathbf{2 0 0 3}$ & $\mathbf{2 0 0 6}$ & $\mathbf{2 0 0 9}$ & $\mathbf{2 0 1 2}$ \\
\hline $\begin{array}{l}\text { Decile 1 } \\
\text { Average working days }\end{array}$ & 5.77 & 5.93 & 5.82 & 5.68 & 5.79 \\
\hline Average working hours & 35.39 & 36.79 & 36.78 & 35.73 & 36.86 \\
\hline $\begin{array}{l}\text { Decile 4 } \\
\text { Average working days }\end{array}$ & 5.72 & 5.93 & 5.85 & 5.76 & 5.92 \\
\hline Average working hours & 36.48 & 38.52 & 38.45 & 38.18 & 40.08 \\
\hline $\begin{array}{l}\text { Decile 7 } \\
\text { Average working days }\end{array}$ & 5.72 & 5.95 & 5.9 & 5.82 & 5.92 \\
\hline Average working hours & 37.85 & 40.09 & 40.72 & 40.27 & 42.25 \\
\hline $\begin{array}{l}\text { Decile 10 } \\
\text { Average working days }\end{array}$ & 5.80 & 5.93 & 5.91 & 5.79 & 5.85 \\
\hline Average working hours & 41.80 & 43.31 & 45.13 & 43.62 & 45.04 \\
\hline Average (all deciles) & & & & & \\
\hline Average working days & 5.75 & 5.94 & 5.88 & 5.78 & 5.89 \\
\hline Average working hours & 37.74 & 39.60 & 40.20 & 39.55 & 41.11 \\
\hline
\end{tabular}

Note: TNP2K calculations based on Susenas rounds. Survey weights applied. 
Table 8 and figures 12 and 13 further disaggregate the previous decile statistics for 2012 by gender and location. In line with the previous findings, we observed that men and women who belong to the working poor work fewer hours a week on average than men and women in the richer deciles. The working hour gap between poorer and richer workers is more pronounced among women. Although men who belong to the working poor (decile 1) work on average about 6 hours fewer per week than men in decile 10 (36.6 hours compared with 45.7 hours); women in decile 1 work about 12 hours less per week than women in decile 10 .

Table 8: Length of Work by Gender and Area (2012)

\begin{tabular}{|c|c|c|c|c|c|}
\hline \multirow{2}{*}{ Length of Work } & \multirow{2}{*}{ Total } & \multicolumn{2}{|c|}{ Gender } & \multicolumn{2}{|c|}{ Area } \\
\hline & & Male & Female & Rural & Urban \\
\hline \multicolumn{6}{|l|}{ Decile 1} \\
\hline Average working hours & 36.86 & 39.60 & 32.23 & 34.12 & 42.05 \\
\hline Average working days & 5.79 & 5.88 & 5.64 & 5.70 & 5.96 \\
\hline \multicolumn{6}{|l|}{ Decile 4} \\
\hline Average working hours & 40.08 & 42.25 & 36.27 & 37.35 & 44.08 \\
\hline Average working days & 5.92 & 5.96 & 5.86 & 5.86 & 6.01 \\
\hline \multicolumn{6}{|l|}{ Decile 7} \\
\hline Average working hours & 42.25 & 44.24 & 38.77 & 39.12 & 45.74 \\
\hline Average working days & 5.92 & 5.95 & 5.88 & 5.81 & 6.05 \\
\hline \multicolumn{6}{|l|}{ Decile 10} \\
\hline Average working hours & 45.04 & 45.70 & 44.05 & 40.72 & 46.13 \\
\hline Average working days & 5.85 & 5.82 & 5.88 & 5.82 & 5.85 \\
\hline \multicolumn{6}{|l|}{ Average (all deciles) } \\
\hline Average working hours & 41.11 & 43.05 & 37.85 & 37.58 & 44.87 \\
\hline Average working days & 5.89 & 5.93 & 5.83 & 5.80 & 5.98 \\
\hline
\end{tabular}

Note: TNP2K calculations based on Susenas rounds. Survey weights applied.

Furthermore, in line with previous findings, there are important differences in working hours along the wealth distribution between rural and urban areas. However, in contrast to the gender gap described above, we only observed relatively moderate working-hour differences along the wealth gradient within rural and urban areas. Working poor in rural areas work on average 6.5 hours less than rural workers who belong to the richest decile (34.1 hours compared with 40.7 hours); whereas urban working poor work on average about 4 hours less than urban workers in the richest decile ( 42 hours compared with 46 hours). Interestingly, the working-hour gap between rural and urban hours is so large that the urban working poor work on average more than the richest workers in rural areas (42 hours compared with 40.7 hours). 
Figure 12: Length of Work by Gender (2012)

\section{Average Length of Working Hours by Gender}

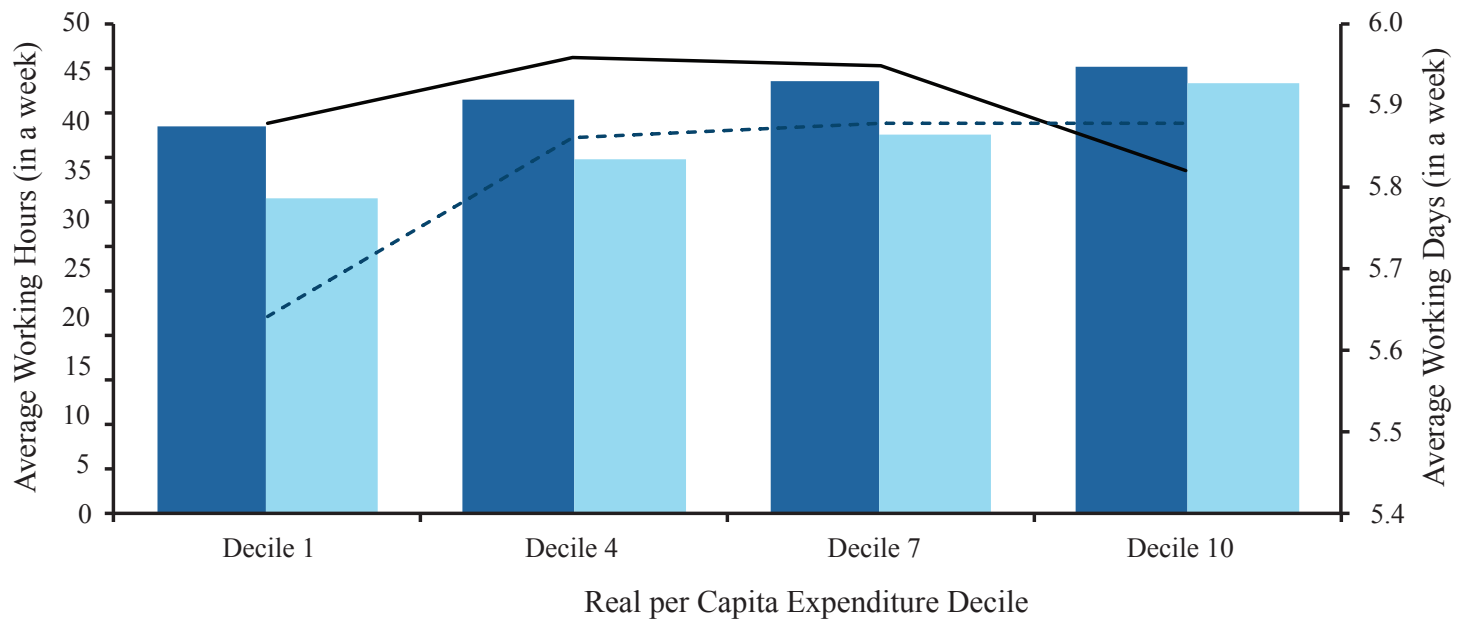

Male Female $\quad$ Male $\quad$-.-. Female

Note: TNP2K calculations based on Susenas rounds. Survey weights applied.

Figure 13: Length of Work by Area (2012)

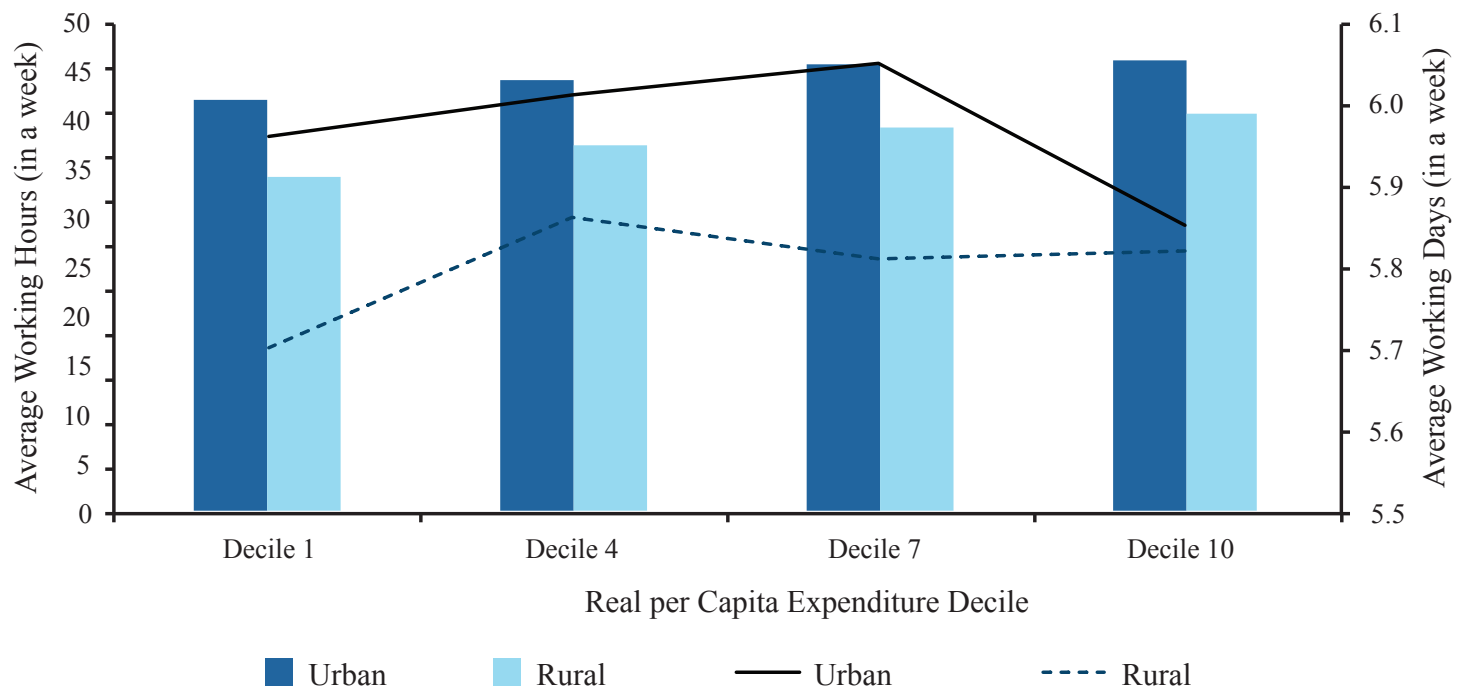

Note: TNP2K calculations based on Susenas rounds. Survey weights applied. 


\section{Who Are the Working Poor?}

The previous chapter analysed differences in labour market patterns of workers along the wealth distribution. From this analysis, one finds that LFPRs between the poor and nonpoor are very similar in Indonesia. However, the working poor work fewer hours on average and presumably receive lower hourly wages than better-off workers receive. In combination, these factors are assumed to be the main reasons why workers are poor or not poor. The reason for differences in working hours and hourly wages/income likely lies in differences in the underlying characteristics of poor workers, such as lower levels of education, living in regions with lower wages, and/or working in occupations/sectors that in general provide lower wages/incomes. This section investigates to what extent workers differ in basic socioeconomic and sectoral characteristics at different wealth levels and how these characteristics and differences have evolved over time ${ }^{8}$.

\section{Socioeconomic Characteristics of the Working Poor vs. the Working Nonpoor}

\section{Demographic Structure}

Table 9 depicts mean values for a variety of important socioeconomic, spatial, and sectoral characteristics across real expenditure per capita deciles. The working poor - defined as workers in decile 1 - comprise a relatively high share of youth (15 to 24 years) and elderly (55+ years) workers. Adults of prime working age (25 to 55 years) are less likely to be poor and fewer are found in the lower expenditure deciles. Because younger workers are starting their work life, their wages/income might initially be very low due to their lower levels of work experience. Likewise, the elderly are represented relatively strongly among the working poor. The high share of the elderly among the poor is of concern as this group is generally without any sort of formal pension and has very limited opportunities to save enough resources to pay for their daily living costs in old age (Priebe and Howell 2014).

An important factor to bear in mind when interpreting the age structure in this context is selection effects. Children from poorer families are more likely to enter the job market at younger ages, whereas children from wealthier families are more likely not to drop out of school and to continue on to secondary or postsecondary schools. Likewise, as shown in a working paper on old-age poverty in Indonesia (Priebe and Howell 2014), better-off elderly are more likely to retire and withdraw from the labour force. Therefore, poor elderly are overrepresented in the labour force, which leads to their relatively high share in the poorest deciles. As a consequence, the group of working poor constitute a relatively large share, as well as number, of children from poor families and poor elderly persons.

\footnotetext{
8 The subsequent analysis considers anyone who usually works at least 1 hour a week (including underemployed and those employed full-time).
} 
Table 9: Demographic Structure of Working Persons across Deciles (2000-12)

Decile 1

Age:

\begin{tabular}{|llllll|}
\hline Young: $15-24(\%)$ & 20.25 & 18.79 & 19.03 & 17.07 & 16.25 \\
\hline Adult: $25-54(\%)$ & 67.55 & 68.27 & 68.41 & 67.40 & 67.97 \\
\hline Old: $55+(\%)$ & 12.21 & 12.94 & 12.56 & 15.53 & 15.78 \\
\hline Average household size & 5.03 & 4.81 & 4.99 & 4.76 & 4.62 \\
Average HH dependency ratio & 0.73 & 0.71 & 0.71 & 0.76 & 0.71 \\
Decile 4 & & & & &
\end{tabular}

Age:

\begin{tabular}{|c|c|c|c|c|c|}
\hline Young: 15-24 (\%) & 17.42 & 17.04 & 15.56 & 15.10 & 15.21 \\
\hline Adult: $25-54(\%)$ & 68.92 & 69.65 & 70.14 & 68.63 & 70.35 \\
\hline Old: $55+(\%)$ & 13.66 & 13.30 & 14.30 & 16.27 & 14.44 \\
\hline Average household size & 4.21 & 4.05 & 3.96 & 3.81 & 3.86 \\
\hline Average $\mathrm{HH}$ dependency ratio & 0.57 & 0.56 & 0.53 & 0.53 & 0.53 \\
\hline \multicolumn{6}{|l|}{ Decile 7} \\
\hline \multicolumn{6}{|l|}{ Age: } \\
\hline Young: 15-24 (\%) & 16.13 & 15.68 & 14.33 & 14.38 & 14.46 \\
\hline Adult: $25-54(\%)$ & 69.54 & 70.46 & 71.22 & 70.29 & 71.77 \\
\hline Old: $55+(\%)$ & 14.33 & 13.86 & 14.45 & 15.34 & 13.77 \\
\hline Average household size & 3.59 & 3.52 & 3.48 & 3.43 & 3.51 \\
\hline Average HH dependency ratio & 0.46 & 0.45 & 0.42 & 0.42 & 0.44 \\
\hline \multicolumn{6}{|l|}{ Decile 10} \\
\hline \multicolumn{6}{|l|}{ Age: } \\
\hline Young: 15-24 (\%) & 14.26 & 13.77 & 12.58 & 13.84 & 13.50 \\
\hline Adult: $25-54(\%)$ & 71.24 & 72.6 & 74.78 & 74.05 & 75.06 \\
\hline Old: $55+(\%)$ & 14.49 & 13.64 & 12.64 & 12.11 & 11.44 \\
\hline Average household size & 2.66 & 2.65 & 2.87 & 2.82 & 2.87 \\
\hline Average $\mathrm{HH}$ dependency ratio & 0.23 & 0.23 & 0.24 & 0.24 & 0.27 \\
\hline \multicolumn{6}{|l|}{ Average (all deciles) } \\
\hline \multicolumn{6}{|l|}{ Age: } \\
\hline Young: 15-24 (\%) & 16.87 & 16.13 & 15.04 & 14.88 & 15.08 \\
\hline Adult: $25-54(\%)$ & 69.11 & 70.36 & 71.16 & 69.99 & 71.32 \\
\hline Old: $55+(\%)$ & 14.02 & 13.51 & 13.81 & 15.13 & 13.60 \\
\hline Average household size & 3.71 & 3.61 & 3.64 & 3.58 & 3.62 \\
\hline Average HH dependency ratio & 0.47 & 0.46 & 0.45 & 0.46 & 0.45 \\
\hline
\end{tabular}

Note: TNP2K calculations based on Susenas rounds. Survey weights applied. HH: household. 
Furthermore, the working poor are more likely to live in households with many family members (larger household size) and with a high dependency ratio (a relatively large share of young children and elderly compared with adults in prime working age). The income of the working poor therefore needs to provide for significantly more persons than in the case of nonpoor workers. Hence, the need to share income among a larger group of poor persons further contributes to the number of workers living in poverty, despite working a substantial number of hours each week.

\section{Education and Skill Levels of the Working Poor}

In the past few decades, Indonesia has experienced significant improvements in literacy and school enrolment rates throughout the country. A large program for the construction of more than 243,000 schools began in the 1970s and strongly contributed to Indonesia achieving primary school enrolment rates of close to $100 \%$ (Suharti 2013), which in turn led to higher labour force participation rates and wage increases among the poor (Duflo 2001, 2004). In general, the period from the 1970s until today has seen a substantial and steady increase in primary, secondary, and tertiary education completion rates and the gap in years of education between the poor and the rich has narrowed over time (Fahmi and Satriatna 2013). However, substantial differences in the quality of education continue to hamper skills development in the country (Suharti 2013).

Scholars (Duflo 2004; Purnastuti et al. 2013) have observed that the rise in education levels in Indonesia has led on average to moderate declines in the rate of returns to education, implying that the value of a given education degree received in the 1980s paid relatively more than in 2014 . However, although the relative benefit of higher secondary over primary schooling might have been greater in the $1980 \mathrm{~s}$, one must bear in mind that workers with higher secondary education qualifications on average continue to receive significantly higher incomes and wages compared with workers with only primary-level schooling.

In line with the education and labour market literature on Indonesia, we found that a worker's education level is significantly associated with belonging to the working poor (figure 14 and table 10). Although in 2012 about $70 \%$ of workers in the bottom decile (decile 1) possessed primary education or less, only $17 \%$ of workers that belong to the richest decile (decile 10) had primary school degrees or less. In fact, along the wealth distribution, the share of workers with higher secondary schooling and especially tertiary education rises continuously.

An interesting labour market trend, shown in table 10 and figure 15, is the increasing polarization of education levels along the wealth distribution in 2000-12; the tendency is for workers with higher secondary and tertiary education degrees to be much more dominant in richer deciles. Although higher secondary and tertiary education degrees by and large seem to reliably protect against poverty, all other education levels (less than completed primary schooling, and completed lower secondary schooling) no longer guarantee adequate employment to protect workers from poverty. Workers without a higher secondary or tertiary education degree are significantly more likely to belong to one of the poorer deciles. 
Figure 14: Distribution of Workers by Educational Attainment (2012)

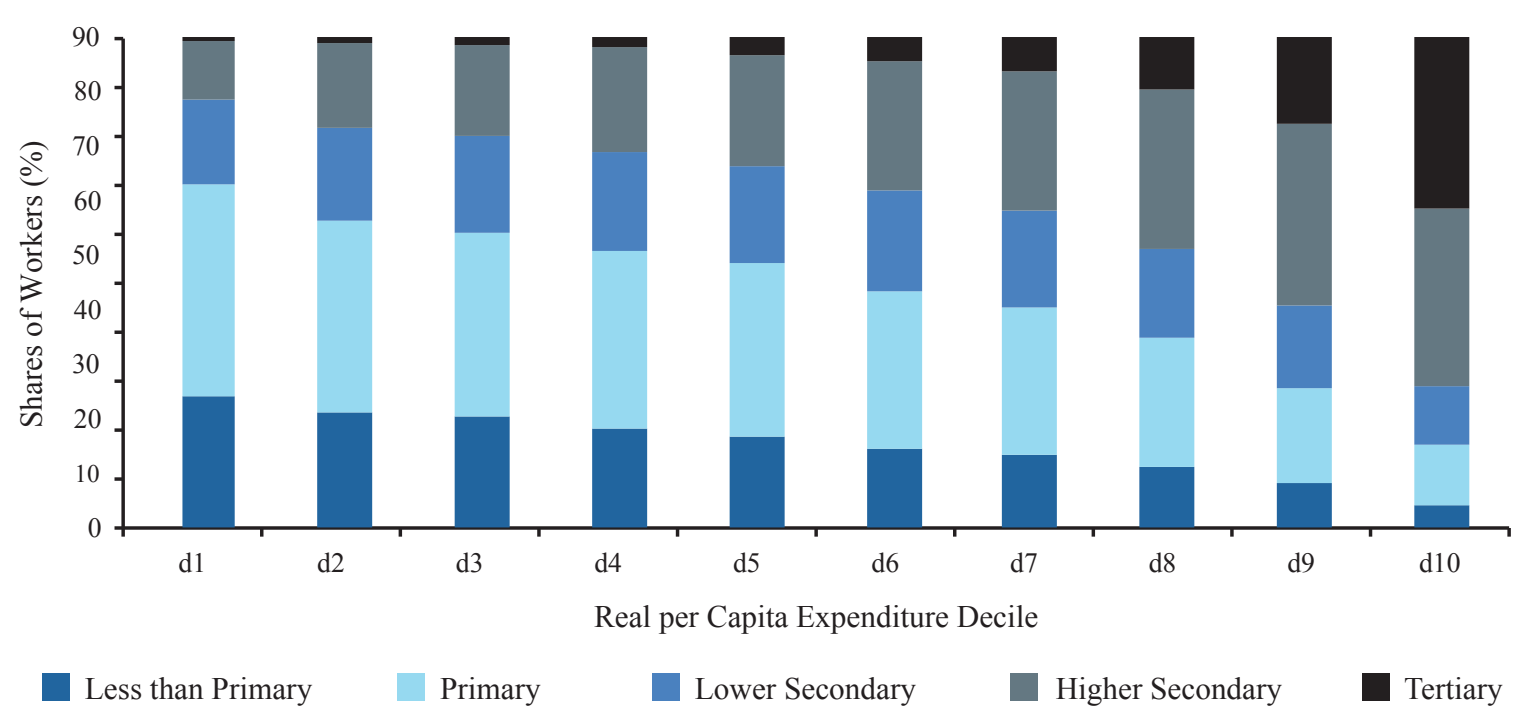

Table 10: Distribution of Workers by Educational Attainment (2000-12)

\begin{tabular}{lccccc}
\hline Educational Attainment Rates & $\mathbf{2 0 0 0}(\mathbf{\%})$ & $\mathbf{2 0 0 3}(\mathbf{\%})$ & $\mathbf{2 0 0 6}(\mathbf{\%})$ & $\mathbf{2 0 0 9}(\mathbf{\%})$ & $\mathbf{2 0 1 2}(\mathbf{\%})$ \\
\hline Decile $\mathbf{1}$ & & & & & \\
Less than primary & 32.01 & 28.72 & 25.46 & 26.86 & 26.79 \\
\hline Primary & 45.08 & 46.76 & 47.29 & 44.17 & 43.22 \\
\hline Lower secondary & 13.02 & 15.17 & 16.77 & 17.16 & 17.14 \\
\hline Higher secondary & 9.33 & 8.78 & 9.95 & 10.96 & 11.86 \\
\hline Tertiary & 0.56 & 0.57 & 0.52 & 0.85 & 0.99 \\
Decile 4 & & & & & \\
Less than primary & 25.98 & 22.22 & 20.73 & 21.23 & 20.31 \\
\hline Primary & 42.58 & 42.82 & 41.56 & 39.06 & 36.23 \\
\hline Lower secondary & 15.32 & 17.68 & 19.22 & 19.21 & 19.90 \\
\hline Higher secondary & 14.38 & 15.40 & 16.57 & 18.18 & 21.26 \\
\hline Tertiary & 1.74 & 1.87 & 1.92 & 2.32 & 2.30 \\
Decile 7 & & & & & \\
Less than primary & 22.47 & 18.53 & 16.7 & 15.84 & 14.80 \\
\hline Primary & 36.01 & 36.86 & 34.18 & 31.36 & 30.08 \\
\hline Lower secondary & 16.19 & 18.38 & 18.37 & 18.72 & 19.63 \\
\hline Higher secondary & 21.18 & 21.85 & 25.26 & 27.60 & 28.32 \\
\hline Tertiary & 4.15 & 4.38 & 5.50 & 6.47 & 7.17 \\
Decile 10 & 11.55 & 9.84 & 7.45 & 5.84 & 4.62 \\
\hline Less than primary & 21.75 & 21.61 & 16.33 & 14.85 & 12.30 \\
\hline Primary & & & & & \\
\hline
\end{tabular}


Table 10: Distribution of Workers by Educational Attainment (2000-12) [continued]

\begin{tabular}{|lccccc|}
\hline Educational Attainment Rates & $\mathbf{2 0 0 0}(\mathbf{\%})$ & $\mathbf{2 0 0 3}(\mathbf{\%})$ & $\mathbf{2 0 0 6}(\mathbf{\%})$ & $\mathbf{2 0 0 9}(\mathbf{\%})$ & $\mathbf{2 0 1 2}(\mathbf{\%})$ \\
\hline Lower secondary & 14.52 & 14.67 & 12.87 & 12.7 & 11.92 \\
Higher secondary & 33.73 & 33.79 & 34.62 & 35.53 & 36.05 \\
Tertiary & 18.46 & 20.10 & 28.73 & 31.09 & 35.10 \\
Average (full dataset) & & & & & \\
Less than primary & 22.83 & 19.54 & 17.65 & 17.20 & 16.27 \\
\hline Primary & 37.00 & 37.82 & 35.01 & 32.61 & 30.25 \\
\hline Lower secondary & 15.35 & 16.96 & 17.66 & 17.55 & 18.15 \\
\hline Higher secondary & 19.69 & 20.19 & 22.35 & 23.98 & 25.95 \\
\hline Tertiary & 5.13 & 5.48 & 7.33 & 8.66 & 9.38 \\
\hline
\end{tabular}

Note: TNP2K calculations based on Susenas rounds. Survey weights applied.

Figure 15: Distribution of Workers by Educational Attainment (2000-12)

The Bottom 10\%

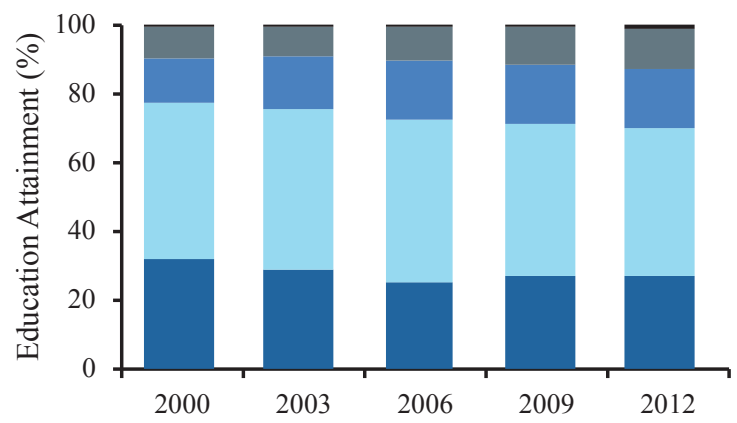

The Top $10 \%$

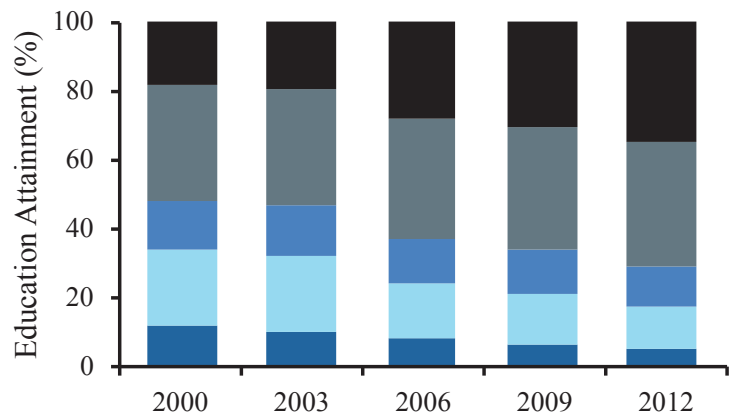

Less than Primary
Primary

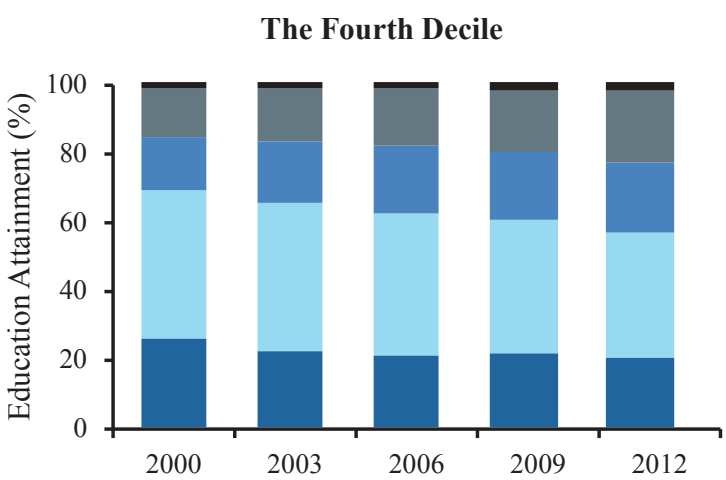

The Seventh Decile

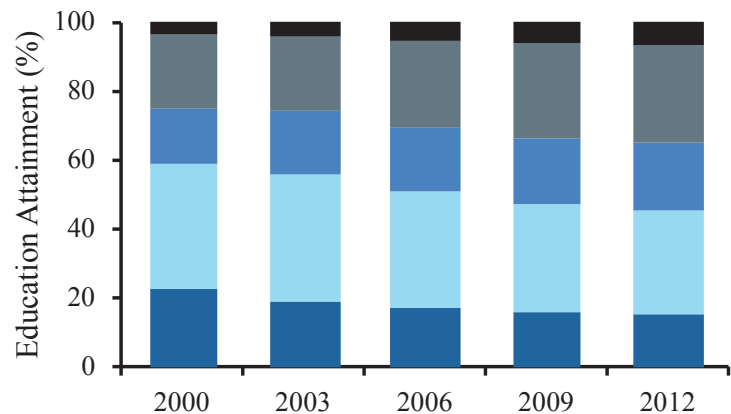

Higher Secondary

Tertiary

Note: TNP2K calculations based on Susenas rounds. Survey weights applied.

Table 11 and figure 16 show education statistics along the wealth distribution disaggregated by gender and area for the year 2012. The results suggest that similar wealth gradients can be observed for men and women. For both men and women, we observed that better-off workers tend to have higher education levels and that only completion of higher secondary education seems to be associated with protection against being poor. With respect to the rural-urban divide, we found that higher levels of education in urban areas are especially associated with higher living standards, whereas in rural areas, we observed 
a weaker correlation between education levels and a person's welfare status. This might point to other factors, such as physical assets and land possession as well as standing in the local community, playing a more important role in a household's welfare status compared with urban areas.

Table 11: Educational Attainment of Workers by Gender and Area (2012)

\begin{tabular}{|c|c|c|c|c|c|}
\hline \multirow{2}{*}{ Educational Attainment } & \multirow{2}{*}{ Total } & \multicolumn{2}{|c|}{ Gender } & \multicolumn{2}{|c|}{ Area } \\
\hline & & Male & Female & Urban & Rural \\
\hline \multicolumn{6}{|l|}{ Decile 1} \\
\hline Less than primary & 26.79 & 25.14 & 29.94 & 22.21 & 29.48 \\
\hline Primary & 43.22 & 42.47 & 44.64 & 39.83 & 45.21 \\
\hline Lower secondary & 17.14 & 18.54 & 14.48 & 18.71 & 16.22 \\
\hline Higher secondary & 11.86 & 12.92 & 9.84 & 17.68 & 8.44 \\
\hline Tertiary & 0.99 & 0.93 & 1.10 & 1.57 & 0.65 \\
\hline \multicolumn{6}{|l|}{ Decile 4} \\
\hline Less than primary & 20.31 & 17.26 & 21.40 & 14.09 & 24.68 \\
\hline Primary & 36.23 & 35.11 & 35.24 & 28.32 & 41.79 \\
\hline Lower secondary & 19.90 & 20.73 & 18.29 & 21.39 & 18.85 \\
\hline Higher secondary & 21.26 & 23.56 & 20.37 & 32.74 & 13.20 \\
\hline Tertiary & 2.30 & 3.34 & 4.70 & 3.46 & 1.49 \\
\hline \multicolumn{6}{|l|}{ Decile 7} \\
\hline Less than primary & 14.80 & 12.91 & 18.21 & 10.78 & 18.46 \\
\hline Primary & 30.08 & 29.72 & 30.74 & 21.53 & 37.89 \\
\hline Lower secondary & 19.63 & 20.27 & 18.46 & 18.88 & 20.31 \\
\hline Higher secondary & 28.32 & 30.79 & 23.82 & 38.67 & 18.86 \\
\hline Tertiary & 7.17 & 6.30 & 8.76 & 10.13 & 4.47 \\
\hline \multicolumn{6}{|l|}{ Decile 10} \\
\hline Less than primary & 4.62 & 4.13 & 5.37 & 2.87 & 11.52 \\
\hline Primary & 12.30 & 11.02 & 14.21 & 9.41 & 23.67 \\
\hline Lower secondary & 11.92 & 11.57 & 12.45 & 10.83 & 16.20 \\
\hline Higher secondary & 36.05 & 40.14 & 29.96 & 37.99 & 28.42 \\
\hline Tertiary & 35.10 & 33.14 & 38.01 & 38.90 & 20.19 \\
\hline \multicolumn{6}{|l|}{ Average (all deciles) } \\
\hline Less than primary & 16.27 & 14.98 & 18.54 & 10.52 & 21.89 \\
\hline Primary & 30.25 & 30.14 & 30.44 & 21.64 & 38.66 \\
\hline Lower secondary & 18.15 & 18.81 & 16.99 & 17.41 & 18.87 \\
\hline Higher secondary & 25.95 & 28.01 & 22.32 & 35.83 & 16.30 \\
\hline Tertiary & 9.38 & 8.06 & 11.71 & 14.60 & 4.28 \\
\hline
\end{tabular}

Note: TNP2K calculations based on Susenas rounds. Survey weights applied. 
Figure 16: Educational Attainment of Workers by Gender and Area (2012)

Male

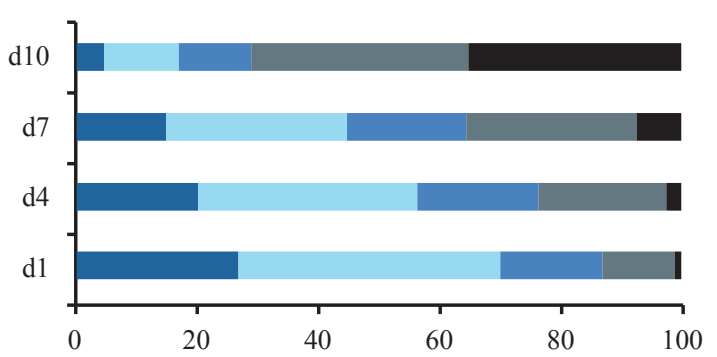

Shares of Male Workers by Educational Attainment (\%)

Female

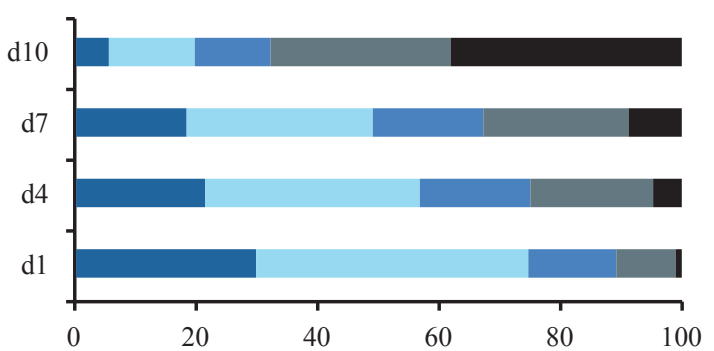

Shares of Female Workers by Educational Attainment (\%)

Less than Primary

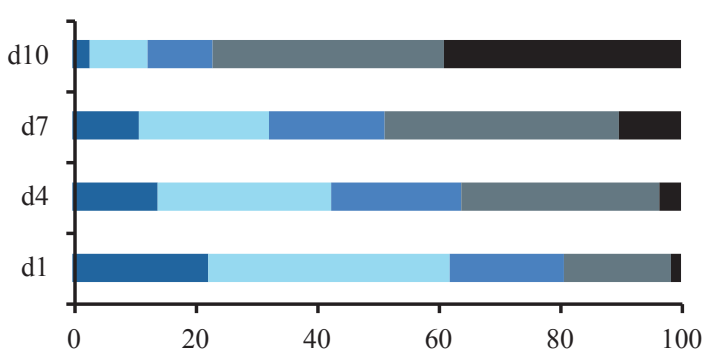

Shares of Urban Workers by Educational Attainment (\%)

Rural

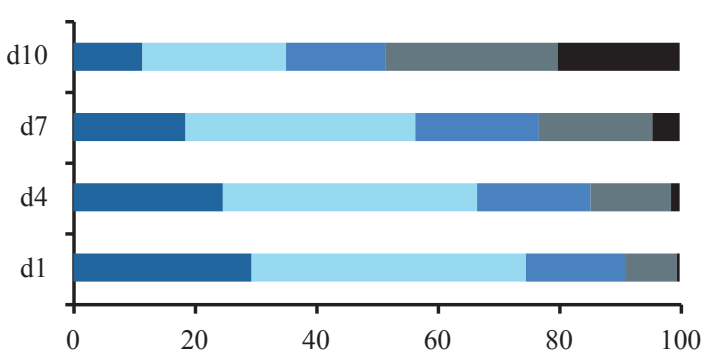

Shares of Rural Workers by Educational Attainment (\%)

Higher Secondary

Tertiary

Note: TNP2K calculations based on Susenas rounds. Survey weights applied.

\section{The Working Poor across Rural and Urban Areas}

The majority of the working poor are concentrated in rural areas, with a widening disparity between rural and urban areas from 2000 to $2012^{9}$. Figure 17 and table 12 show that in 2012 about two-thirds of workers in the poorest decile (decile 1) came from rural areas, whereas the share of rural workers in the richest decile (decile 10) was only about $20 \%$. Furthermore, table 12 and figure 18 show the trend over time for workers in selected deciles: overall, the share of rural workers in poorest decile (decile 1) has remained approximately constant over time, while declining substantially among richer deciles (deciles 7 to 10). This result highlights findings from previous sections that showed that, in 2000-12, the urban labour market created more jobs overall and more full-time employment. Moreover, the findings suggest that recent income and wage growth has been on average weaker in rural compared with urban areas, which increasingly assigns the majority of the working poor to rural areas of Indonesia.

\footnotetext{
9 The actual difference would be even larger if we had used nominal expenditure figures instead of real expenditure figures, as the latter corrects for the living cost differential between rural and urban areas.
} 


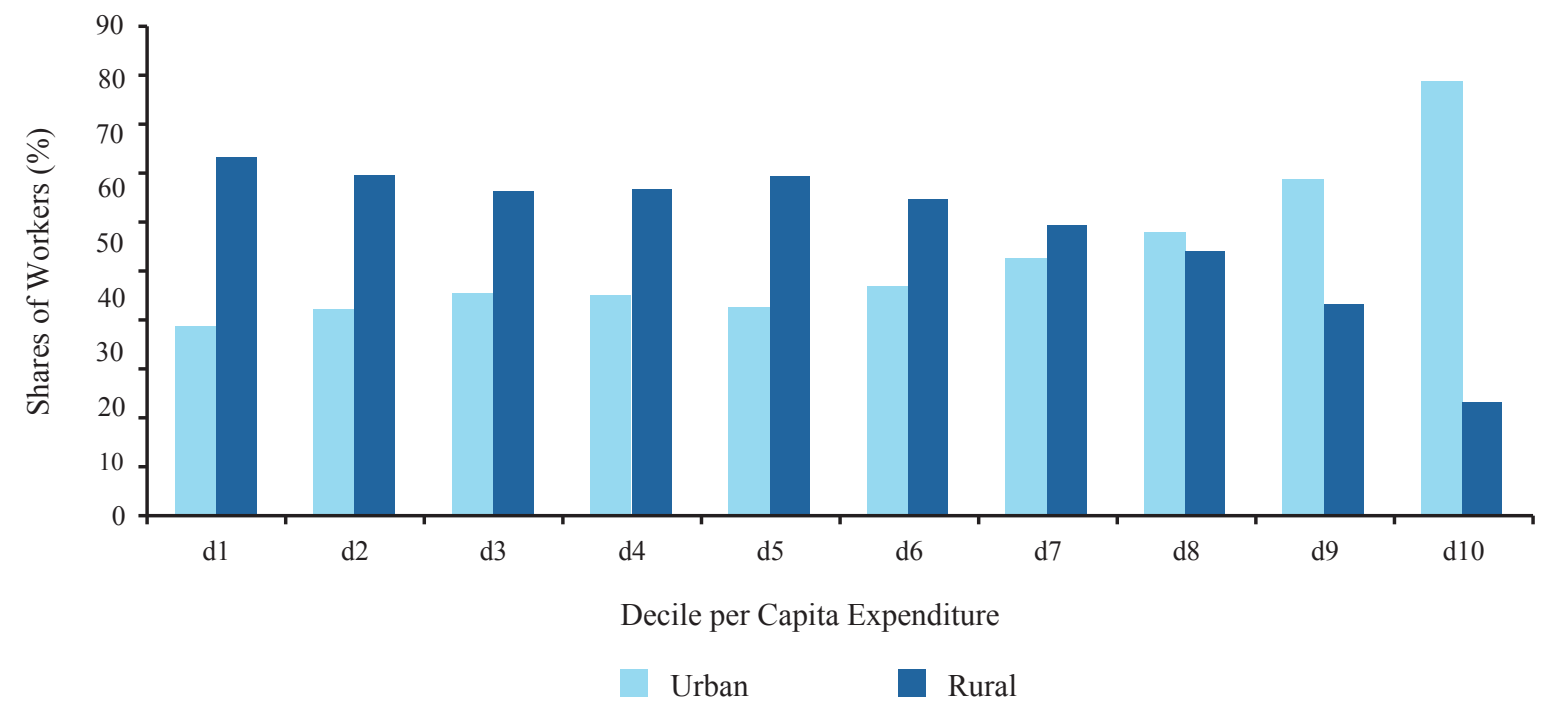

Note: TNP2K calculations based on Susenas rounds. Survey weights applied.

Table 12: Distribution of Workers by Area (2000-12)

\begin{tabular}{|c|c|c|c|c|c|}
\hline Location & $\begin{array}{c}2000 \\
(\%)\end{array}$ & $\begin{array}{l}2003 \\
(\%)\end{array}$ & $\begin{array}{c}2006 \\
(\%)\end{array}$ & $\begin{array}{c}2009 \\
(\%)\end{array}$ & $\begin{array}{c}2012 \\
(\%)\end{array}$ \\
\hline \multicolumn{6}{|l|}{ Decile 1} \\
\hline Urban & 33.94 & 35.78 & 32.01 & 35.01 & 34.52 \\
\hline Rural & 66.06 & 64.22 & 67.99 & 64.99 & 65.48 \\
\hline \multicolumn{6}{|l|}{ Decile 4} \\
\hline Urban & 31.75 & 32.80 & 32.90 & 38.58 & 40.38 \\
\hline Rural & 68.25 & 67.20 & 67.10 & 61.42 & 59.62 \\
\hline \multicolumn{6}{|l|}{ Decile 7} \\
\hline Urban & 37.57 & 37.03 & 41.05 & 46.53 & 47.01 \\
\hline Rural & 62.43 & 62.97 & 58.95 & 53.47 & 52.99 \\
\hline \multicolumn{6}{|l|}{ Decile 10} \\
\hline Urban & 60.23 & 58.59 & 67.75 & 71.89 & 79.31 \\
\hline Rural & 39.77 & 41.41 & 32.25 & 28.11 & 20.69 \\
\hline \multicolumn{6}{|c|}{ Average (all deciles) } \\
\hline Urban & 38.52 & 38.54 & 41.62 & 46.59 & 48.08 \\
\hline Rural & 61.48 & 61.46 & 58.38 & 53.41 & 51.92 \\
\hline
\end{tabular}

Note: TNP2K calculations based on Susenas rounds. Survey weights applied. 


\section{Figure 18: Proportion of Workers by Areas (Selected Deciles)}

The Bottom 10\%

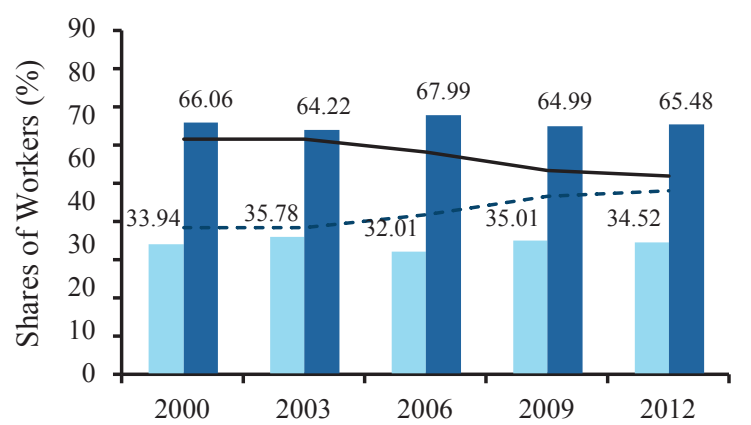

The Top $10 \%$

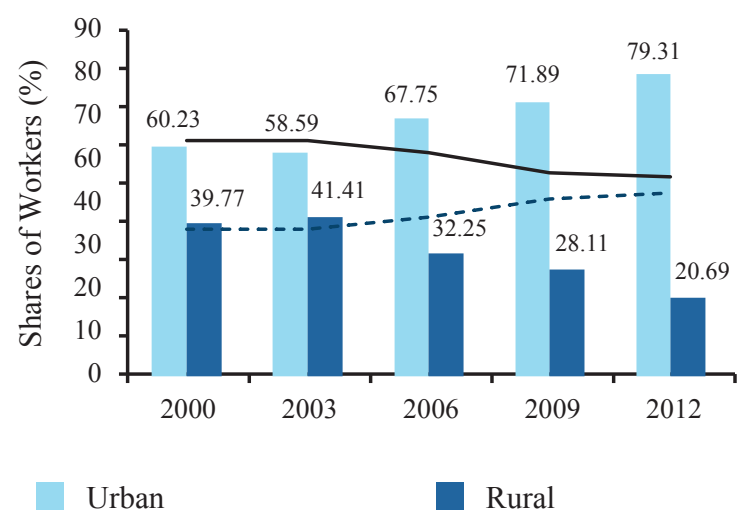

The Fourth Decile

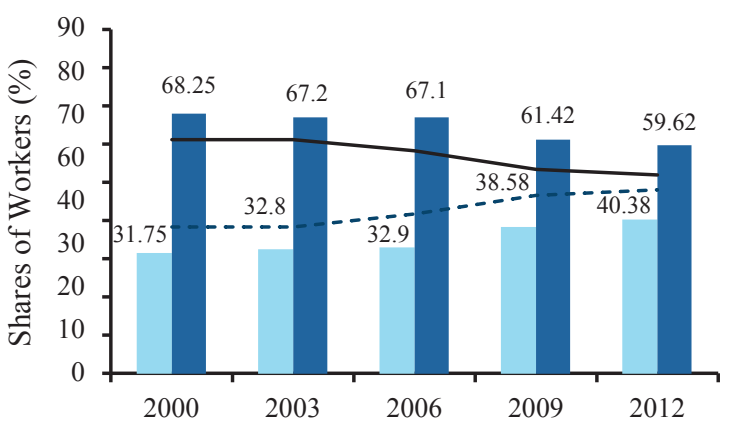

The Seventh Decile

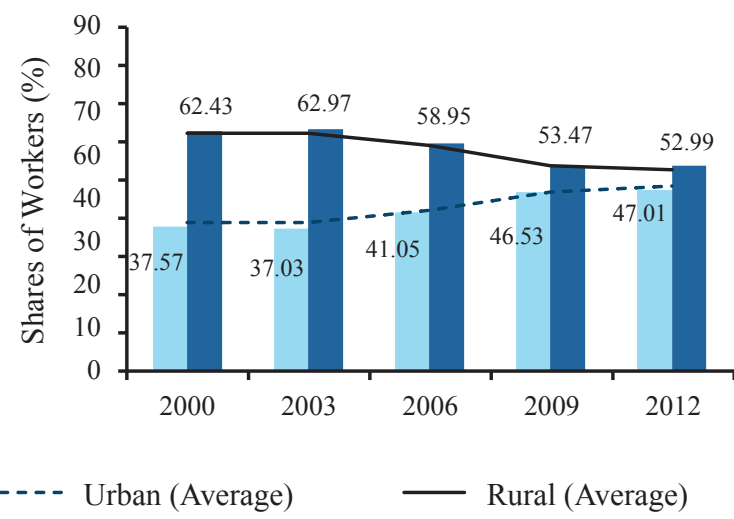

Note: TNP2K calculations based on Susenas rounds. Survey weights applied.

In addition to studying characteristics of the employed (both underemployed and full-time employed), it is worth looking at unemployment rates across wealth deciles over time for both rural and urban areas. In the previous section, we showed that unemployment rates tend to be higher in urban compared with rural areas, even though unemployment rates in urban areas have fallen significantly in recent years. Figure 19 shows the share of workers in the labour force across wealth deciles. In both rural and urban areas, the unemployment rates (the difference between $100 \%$ and the depicted LFPR) are significantly higher among the poor and have been widening in urban areas in recent years. Although unemployment rates among the urban poor decreased with time, the unemployment rates decreased even more strongly for better-off workers. The trends in unemployment rates with time across wealth deciles further underline recent developments in the job market that have been more favourable in urban compared with rural areas during the period 2000-12. 
Figure 19: Share of Workers in the Labour Force by Area and Decile

Proportion of Working Persons by Area (2012)

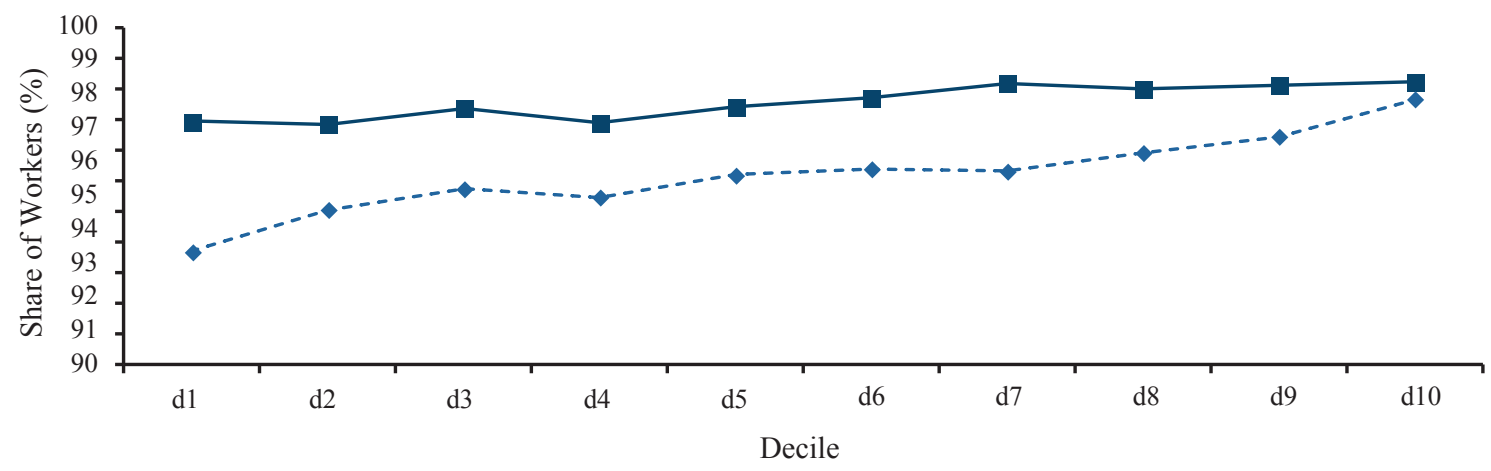

Proportion of Working Persons by Area (2000)

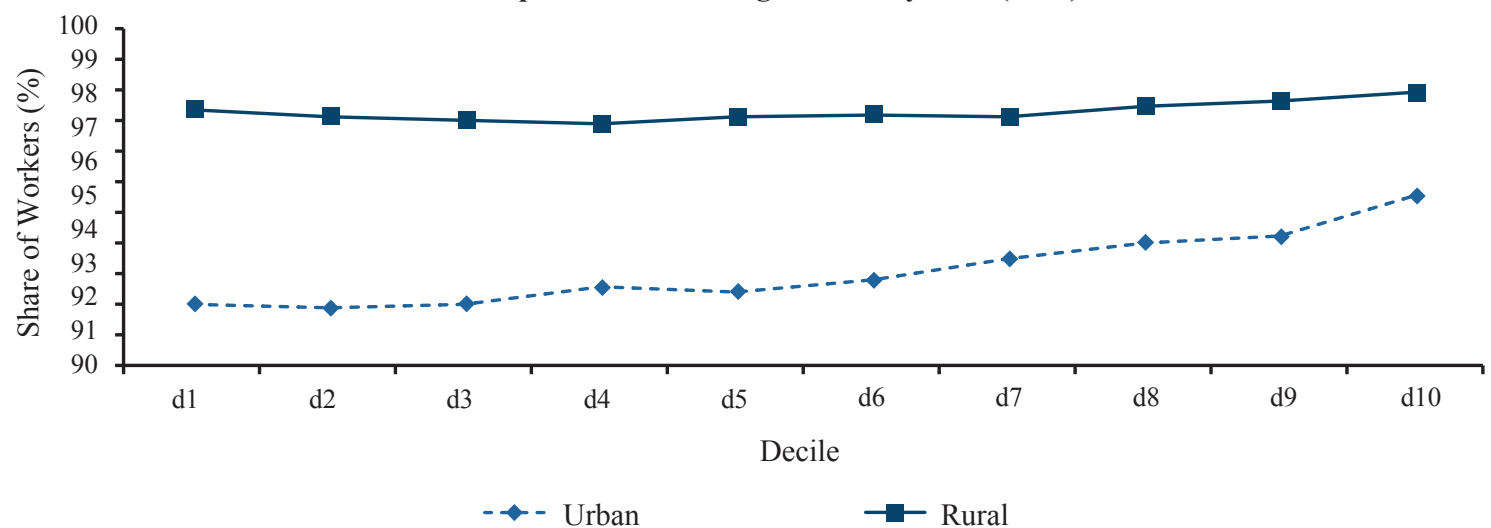

Note: TNP2K calculations based on Susenas rounds. Survey weights applied.

\section{Gender Differences among the Working Poor and the Working Nonpoor}

Men seem slightly overrepresented among the working poor, although the share of men and women remains relatively stable across all wealth deciles. For instance, although the share of women among workers in the poorest decile (decile 1) amounts to $37.26 \%$, the share of women in the richest decile (decile 10) is only slightly higher at $40.44 \%$ (figure 20 and table 13). Furthermore, as table 13 and figure 21 show, this pattern has been remarkably stable over time within deciles, apart from the richest decile, for which the share of women has increased from $37.54 \%$ in 2000 to $40.44 \%$ in 2012 . 
Figure 20: Proportion of Workers by Gender (2012)

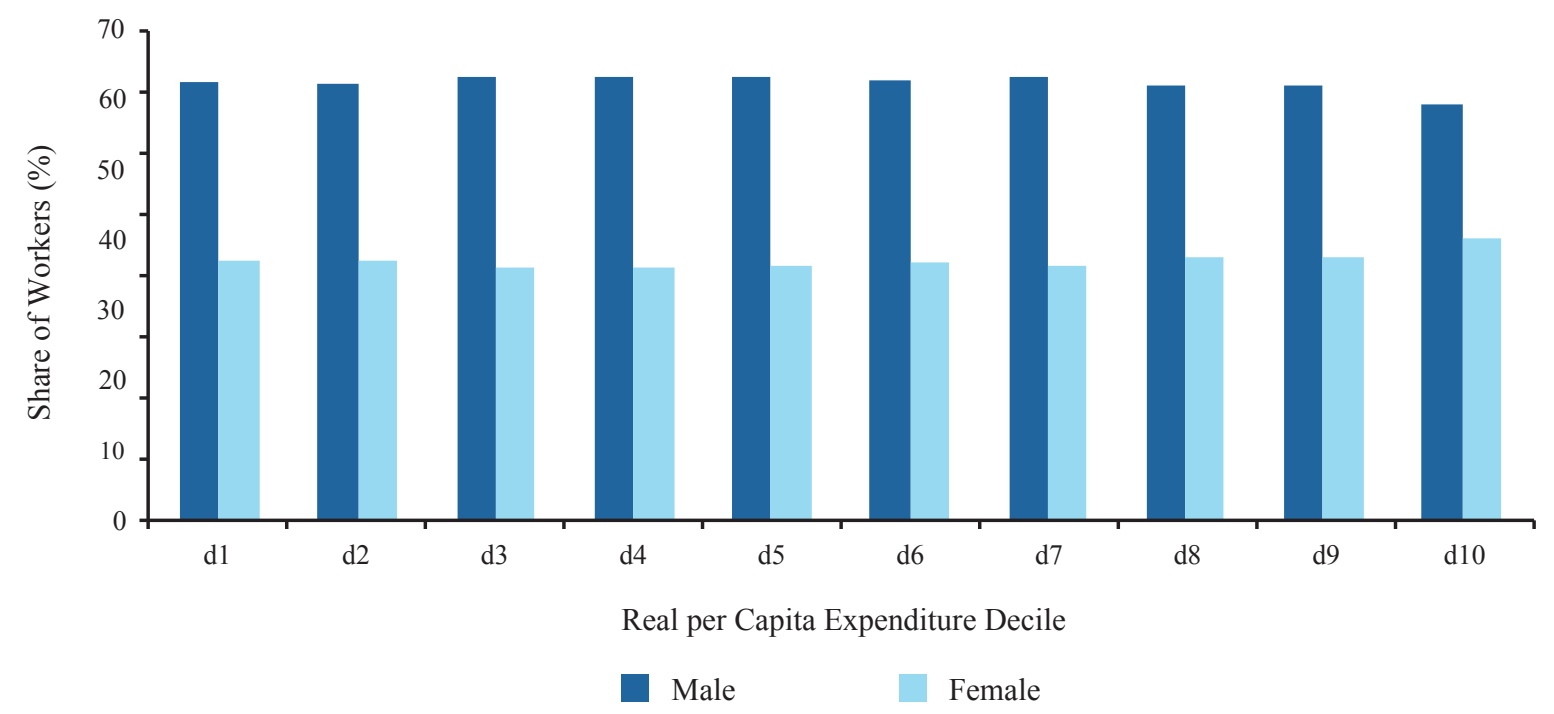

Note: TNP2K calculations based on Susenas rounds. Survey weights applied.

Table 13: Proportion of Workers by Gender (2000-12)

\begin{tabular}{|c|c|c|c|c|c|}
\hline Gender & $2000(\%)$ & $2003(\%)$ & $2006(\%)$ & $2009(\%)$ & $2012(\%)$ \\
\hline \multicolumn{6}{|l|}{ Decile 1} \\
\hline Male & 63.35 & 64.73 & 67.11 & 61.27 & 62.74 \\
\hline Female & 36.65 & 35.27 & 32.89 & 38.73 & 37.26 \\
\hline \multicolumn{6}{|l|}{ Decile 4} \\
\hline Male & 63.94 & 64.93 & 66.97 & 62.07 & 63.67 \\
\hline Female & 36.06 & 35.07 & 33.03 & 37.93 & 36.33 \\
\hline \multicolumn{6}{|l|}{ Decile 7} \\
\hline Male & 64.52 & 65.73 & 66.65 & 61.89 & 63.49 \\
\hline Female & 35.48 & 34.27 & 33.35 & 38.11 & 36.51 \\
\hline \multicolumn{6}{|l|}{ Decile 10} \\
\hline Male & 62.46 & 64.16 & 62.51 & 58.31 & 59.56 \\
\hline Female & 37.54 & 35.84 & 37.49 & 41.69 & 40.44 \\
\hline \multicolumn{6}{|c|}{ Average (all deciles) } \\
\hline Male & 63.78 & 65.27 & 66.19 & 61.42 & 62.63 \\
\hline Female & 36.22 & 34.73 & 33.81 & 38.58 & 37.37 \\
\hline
\end{tabular}

Note: TNP2K calculations based on Susenas rounds. Survey weights applied. 
Figure 21: Proportion of Workers by Gender (Selected Deciles, 2000-12)

The Bottom 10\%

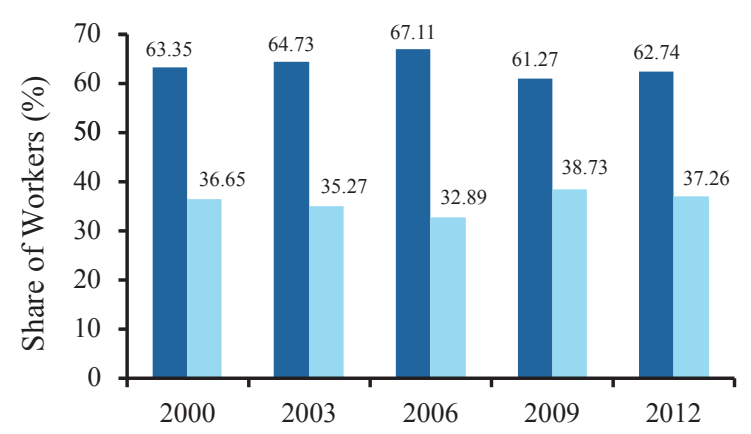

The Top $10 \%$

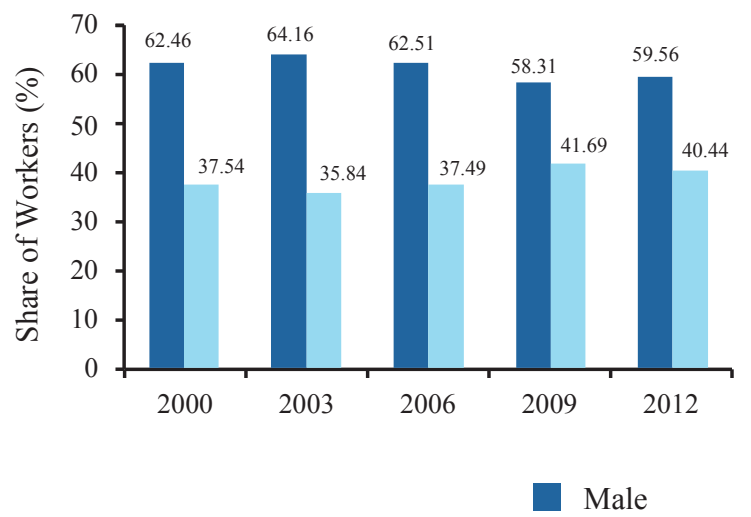

The Fourth Decile

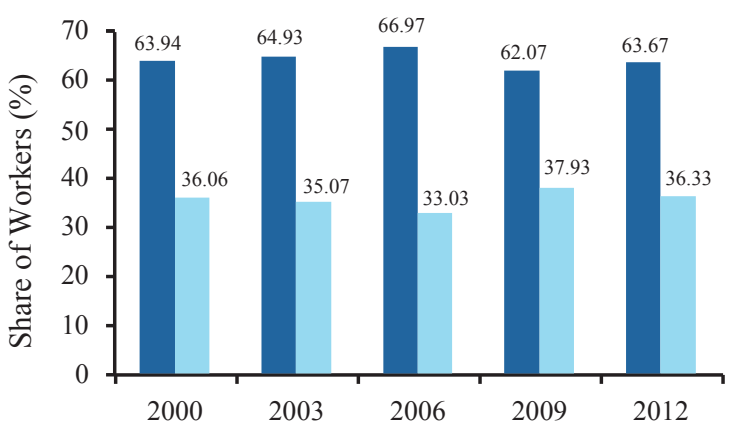

The Seventh Decile

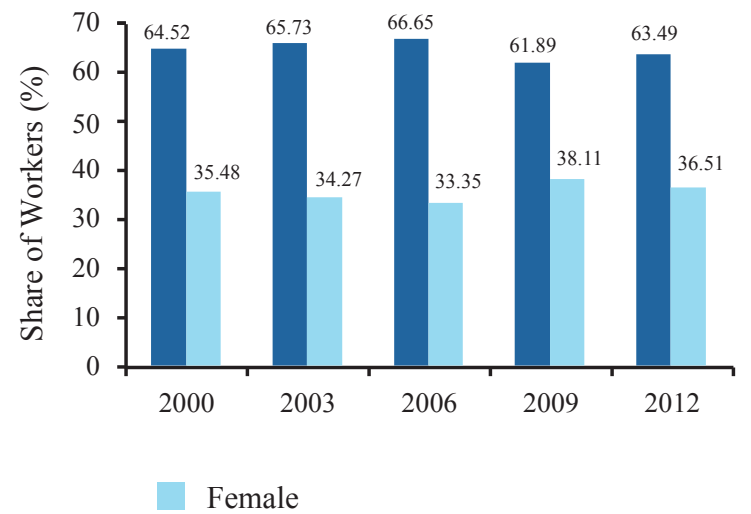

Note: TNP2K calculations based on Susenas rounds. Survey weights applied.

\section{Type of Employment and Sector of Employment}

This subsection looks at differences in the type of employment (self-employed, salaried worker, casual worker, and unpaid worker) and the sector of employment disaggregated for the working poor and the working nonpoor.

\section{Differences in the Type of Employment}

As show in figure 22, the working poor are characterised by a relatively high share of workers who have jobs that are unpaid (22.06\%) and unstable (casual jobs: 19.37\%). The type of employment that is most strongly and increasingly associated with being better off is salaried employment. However, not all salaried employment provides sufficient wages to avoid entering/escaping poverty. Likewise, a very high share of workers across all expenditure deciles (an average of about 36\%) are self-employed workers. However, these self-employed activities generate a great variation in amounts of income; many of those who are self-employed fail to earn sufficient income. 
Figure 22: Distribution of Workers by Type of Employment (2012)

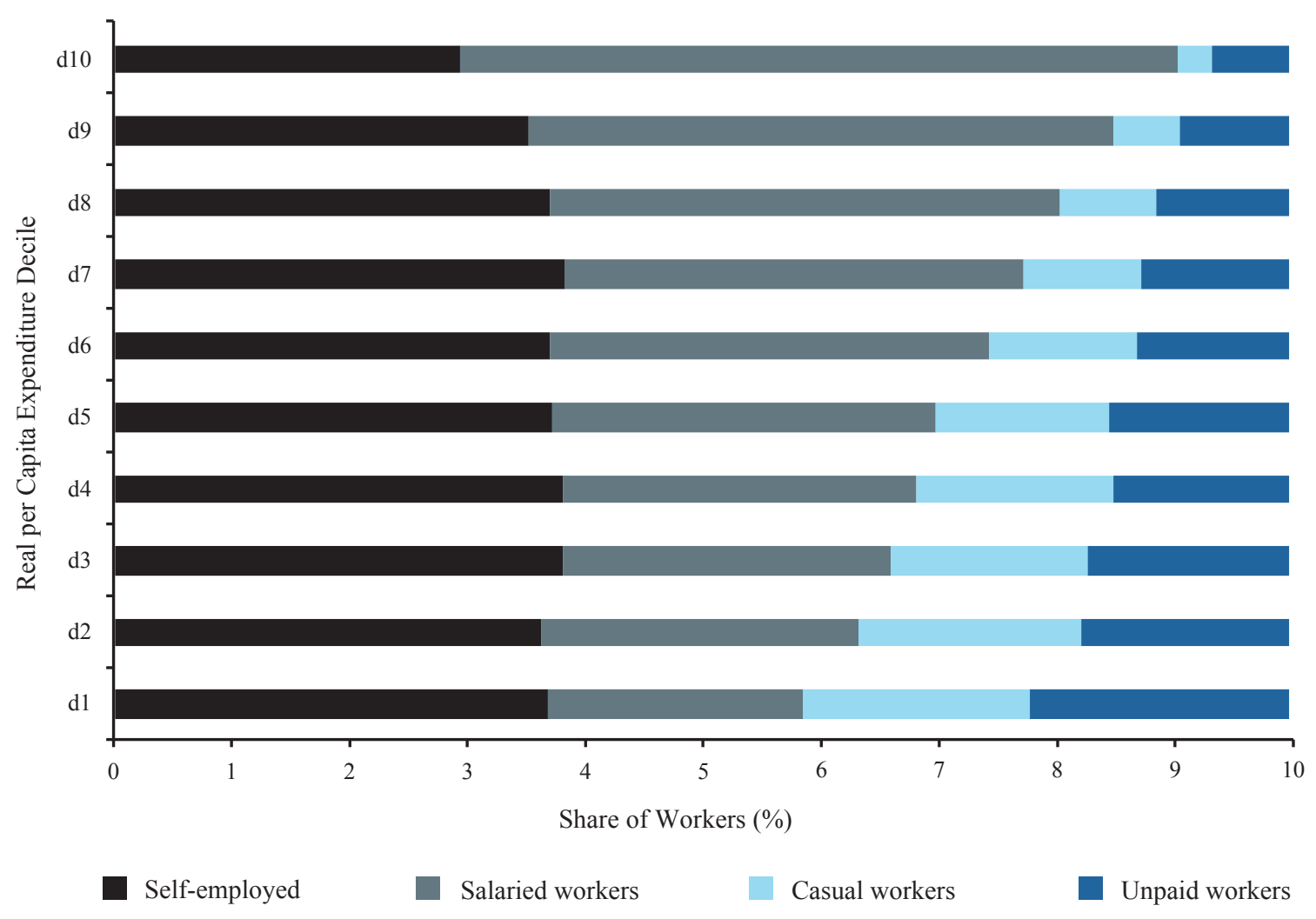

Note: TNP2K calculations based on Susenas rounds. Survey weights applied.

The previous statements are also reflected in the time trend (table 14 and figure 23). Compared with 2003, the share of working poor who are salaried workers remained constant (or even decreased when benchmarked against 2000), whereas overall the share of salaried workers increased, particularly among the richer deciles (decile 7 and decile 10) underscoring that salaried employment is less likely to be associated with poverty in 2012 compared with $2003^{10}$. This finding - that salaried employment is increasingly helping workers to avoid and escape poverty - is consistent with results from academic research, which points to substantial increases in minimum wages in the 1990s and 2000s, which brought many salaried workers and their families out of poverty (Magruder 2013; ILO 2013).

10 Susenas 2000 does not permit distinguishing salaried workers and casual workers. Therefore, we compared 2003 and 2012. 
Table 14: Distribution of Workers by Employment Status (2000-12)

\begin{tabular}{|c|c|c|c|c|c|}
\hline Employment Status & $\begin{array}{c}2000 \\
(\%)\end{array}$ & $\begin{array}{c}2003 \\
(\%)\end{array}$ & $\begin{array}{c}2006 \\
(\%)\end{array}$ & $\begin{array}{c}2009 \\
(\%)\end{array}$ & $\begin{array}{c}2012 \\
(\%)\end{array}$ \\
\hline \multicolumn{6}{|l|}{ Decile 1} \\
\hline Self-employed & 45.46 & 42.70 & 42.76 & 38.31 & 36.88 \\
\hline Salaried workers & 30.45 & 21.82 & 21.50 & 20.56 & 21.69 \\
\hline Casual workers & $\mathrm{n} / \mathrm{a}$ & 13.67 & 16.22 & 18.54 & 19.37 \\
\hline Unpaid workers & 24.09 & 21.81 & 19.53 & 22.59 & 22.06 \\
\hline \multicolumn{6}{|l|}{ Decile 4} \\
\hline Self-employed & 47.47 & 46.29 & 46.03 & 41.46 & 38.13 \\
\hline Salaried workers & 31.62 & 23.52 & 24.28 & 26.57 & 30.17 \\
\hline Casual workers & $\mathrm{n} / \mathrm{a}$ & 9.39 & 13.33 & 13.46 & 16.62 \\
\hline Unpaid workers & 20.91 & 20.80 & 16.36 & 18.51 & 15.08 \\
\hline \multicolumn{6}{|l|}{ Decile 7} \\
\hline Self-employed & 47.73 & 46.05 & 46.42 & 41.94 & 38.25 \\
\hline Salaried workers & 34.81 & 29.96 & 31.56 & 34.45 & 39.07 \\
\hline Casual workers & $\mathrm{n} / \mathrm{a}$ & 7.16 & 8.98 & 8.82 & 9.94 \\
\hline Unpaid workers & 17.46 & 16.83 & 13.04 & 14.79 & 12.74 \\
\hline \multicolumn{6}{|l|}{ Decile 10} \\
\hline Self-employed & 40.89 & 40.23 & 37.41 & 33.17 & 29.47 \\
\hline Salaried workers & 48.45 & 47.67 & 53.65 & 55.90 & 60.95 \\
\hline Casual workers & $\mathrm{n} / \mathrm{a}$ & 2.89 & 2.69 & 2.84 & 3.01 \\
\hline Unpaid workers & 10.66 & 9.22 & 6.24 & 8.10 & 6.56 \\
\hline \multicolumn{6}{|l|}{ Average (all deciles) } \\
\hline Self-employed & 45.97 & 44.84 & 44.36 & 39.69 & 36.29 \\
\hline Salaried workers & 35.57 & 29.32 & 31.68 & 33.52 & 37.75 \\
\hline Casual workers & $\mathrm{n} / \mathrm{a}$ & 8.16 & 10.38 & 10.82 & 12.20 \\
\hline Unpaid workers & 18.46 & 17.68 & 13.58 & 15.97 & 13.76 \\
\hline
\end{tabular}

Note: TNP2K calculations based on Susenas rounds. Survey weights applied. For the year 2000, the 'salaried workers' category comprises 'casual workers'as the Susenas 2000 round did not permit distinguishing between both groups. 
Figure 23: Distribution of Workers by Employment Status (2000-12)
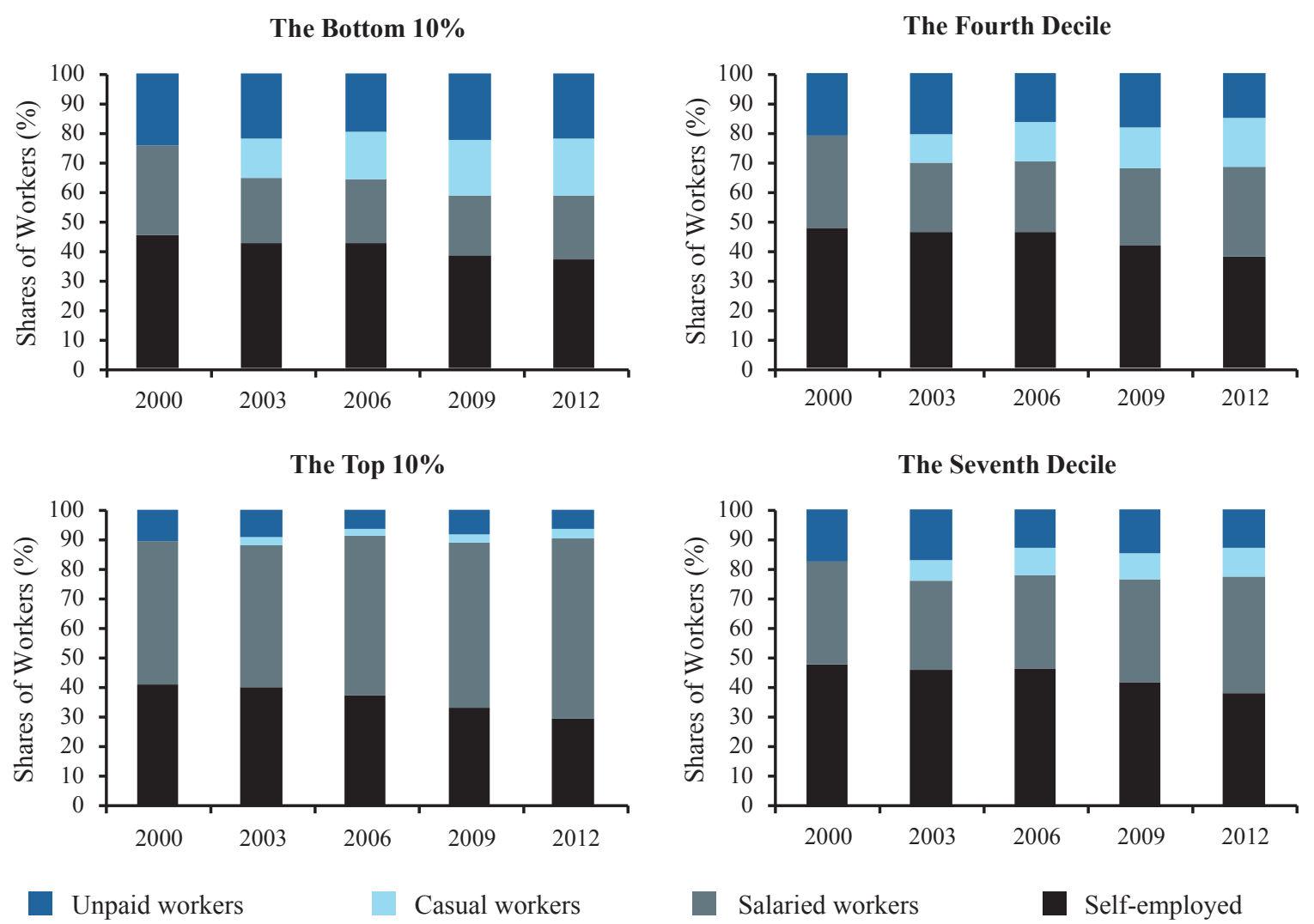

Note: TNP2K calculations based on Susenas rounds. Survey weights applied.

Table 15 shows the previous labour market information further disaggregated by gender and area. The data show that, although men across all wealth deciles are largely engaged in paid work (selfemployment, salaried worker, or casual worker), the share of unpaid female workers is significant throughout the entire expenditure distribution. However, unpaid work among women follows a strong wealth gradient: better-off women are significantly less likely to be engaged in unpaid work than poorer women are. For both men and women, we observed that salaried employment is significantly associated with higher living standards, although one must bear in mind that many male and female salaried workers still belong to the working poor.

With respect to the rural-urban divide, we found that, in both areas, salaried employment is associated with higher living standards as proxied by household expenditures per capita. There seem to be important differences in the type of self-employment activities between rural and urban areas. Although selfemployment in urban areas seems to be slightly associated with lower welfare levels, the opposite can be found for rural areas. Given that the agricultural sector still dominates the rural economy, it appears plausible that land ownership combined with self-employment in agriculture provides meaningful income for many people in rural areas, while in urban areas, similarly lucrative self-employment opportunities are relatively less available. 
Table 15: Employment Status by Gender and Area (2012)

\begin{tabular}{|c|c|c|c|c|c|}
\hline \multirow[b]{2}{*}{ Employment Status } & \multirow[b]{2}{*}{$\begin{array}{l}\text { Total } \\
(\%)\end{array}$} & \multicolumn{2}{|c|}{ Gender } & \multicolumn{2}{|c|}{ Area } \\
\hline & & $\begin{array}{c}\text { Male } \\
(\%)\end{array}$ & $\begin{array}{c}\text { Female } \\
(\%)\end{array}$ & $\begin{array}{c}\text { Urban } \\
(\%)\end{array}$ & $\begin{array}{c}\text { Rural } \\
(\%)\end{array}$ \\
\hline \multicolumn{6}{|l|}{ Decile 1} \\
\hline Self-employed & 36.88 & 43.45 & 25.81 & 32.91 & 38.97 \\
\hline Salaried workers & 21.69 & 23.56 & 18.54 & 35.00 & 14.67 \\
\hline Casual workers & 19.37 & 22.72 & 13.72 & 23.75 & 17.06 \\
\hline Unpaid workers & 22.06 & 10.27 & 41.93 & 8.34 & 29.30 \\
\hline \multicolumn{6}{|l|}{ Decile 4} \\
\hline Self-employed & 38.13 & 42.18 & 31.01 & 34.25 & 40.75 \\
\hline Salaried workers & 30.17 & 33.00 & 25.23 & 45.80 & 19.59 \\
\hline Casual workers & 16.62 & 18.47 & 13.39 & 13.34 & 18.85 \\
\hline Unpaid workers & 15.08 & 6.35 & 30.37 & 6.61 & 20.82 \\
\hline \multicolumn{6}{|l|}{ Decile 7} \\
\hline Self-employed & 38.25 & 40.81 & 33.79 & 33.17 & 42.75 \\
\hline Salaried workers & 39.07 & 42.34 & 33.38 & 53.00 & 26.71 \\
\hline Casual workers & 9.94 & 11.69 & 6.90 & 7.95 & 11.71 \\
\hline Unpaid workers & 12.74 & 5.16 & 25.92 & 5.89 & 18.82 \\
\hline \multicolumn{6}{|l|}{ Decile 10} \\
\hline Self-employed & 29.47 & 31.75 & 26.11 & 26.18 & 42.07 \\
\hline Salaried workers & 60.95 & 61.37 & 60.34 & 66.70 & 38.91 \\
\hline Casual workers & 3.01 & 3.60 & 2.14 & 2.48 & 5.06 \\
\hline Unpaid workers & 6.56 & 3.27 & 11.41 & 4.63 & 13.96 \\
\hline \multicolumn{6}{|l|}{ Average (all deciles) } \\
\hline Self-employed & 36.29 & 39.94 & 30.19 & 30.82 & 41.37 \\
\hline Salaried workers & 37.75 & 39.99 & 33.99 & 53.51 & 23.15 \\
\hline Casual workers & 12.20 & 14.23 & 8.80 & 9.55 & 14.66 \\
\hline Unpaid workers & 13.76 & 5.84 & 27.02 & 6.13 & 20.82 \\
\hline
\end{tabular}

Note: TNP2K calculations based on Susenas rounds. Survey weights applied.

As noted above, individuals classified as being part of the working poor are less likely to engage in full-time employment and are more likely to be in unpaid and unstable jobs. In line with common expectations, we also found a large percentage of people who work in the informal sector classified as working poor (table 16 and figure 24). For example, in 2012 about $77 \%$ of the working poor worked in the informal sector, while only about a third of the workers in the richest decile (decile 10) belonged to the informal sector. 


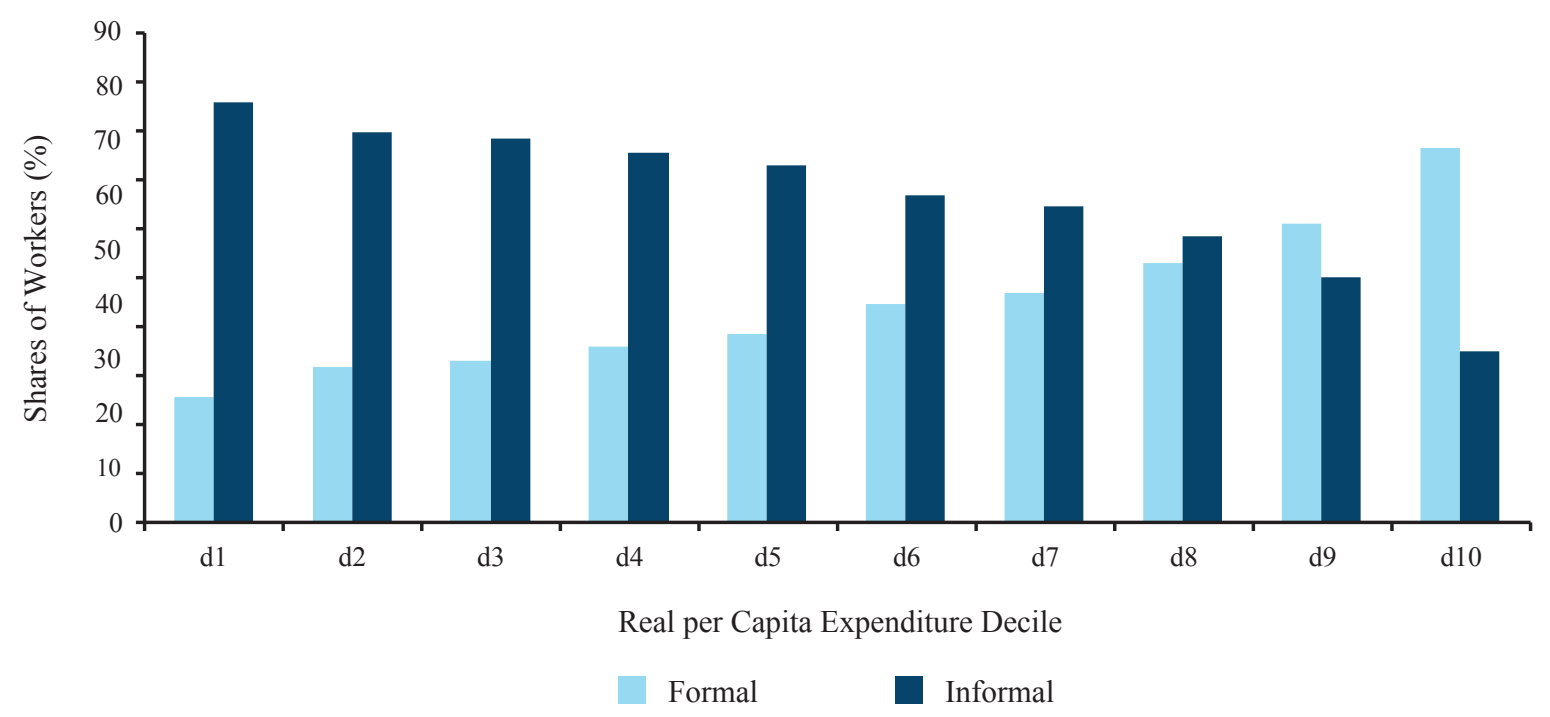

Note: TNP2K calculations based on Susenas rounds. Survey weights applied.

In line with the previous results, we found (table 16 and figure 25) that being part of the informal sector labour force is increasingly associated with lower income levels and poverty. Between 2000 and 2012, the share of the working poor engaged in the informal sector increased, despite the overall share of the informal sector (out of all employment) slightly decreasing from $62.63 \%$ in 2000 to $59.07 \%$ in 2012 .

Table 16: Distribution of Workers by Sector's Formality (2000-12)

\begin{tabular}{|c|c|c|c|c|c|}
\hline Sector's Formality & $2000(\%)$ & $2003(\%)$ & $2006(\%)$ & $2009(\%)$ & $2012(\%)$ \\
\hline \multicolumn{6}{|l|}{ Decile 1} \\
\hline Formal & 31.28 & 23.54 & 23.36 & 21.75 & 22.75 \\
\hline Informal & 68.72 & 76.46 & 76.64 & 78.25 & 77.25 \\
\hline \multicolumn{6}{|l|}{ Decile 4} \\
\hline Formal & 32.68 & 25.91 & 26.71 & 28.41 & 32.16 \\
\hline Informal & 67.32 & 74.09 & 73.29 & 71.59 & 67.84 \\
\hline \multicolumn{6}{|l|}{ Decile 7} \\
\hline Formal & 36.5 & 33.35 & 35.12 & 37.28 & 41.97 \\
\hline Informal & 63.5 & 66.65 & 64.88 & 62.72 & 58.03 \\
\hline \multicolumn{6}{|l|}{ Decile 10} \\
\hline Formal & 53.24 & 54.8 & 61.77 & 63.88 & 68.77 \\
\hline Informal & 46.76 & 45.2 & 38.23 & 36.12 & 31.23 \\
\hline \multicolumn{6}{|l|}{ Average (full dataset) } \\
\hline Formal & 37.37 & 32.74 & 35.29 & 36.58 & 40.93 \\
\hline Informal & 62.63 & 67.26 & 64.71 & 63.42 & 59.07 \\
\hline
\end{tabular}

Note: TNP2K calculations based on Susenas rounds. Survey weights applied. 
Figure 25: Proportion of Workers by Sector's Formality (Selected Years)
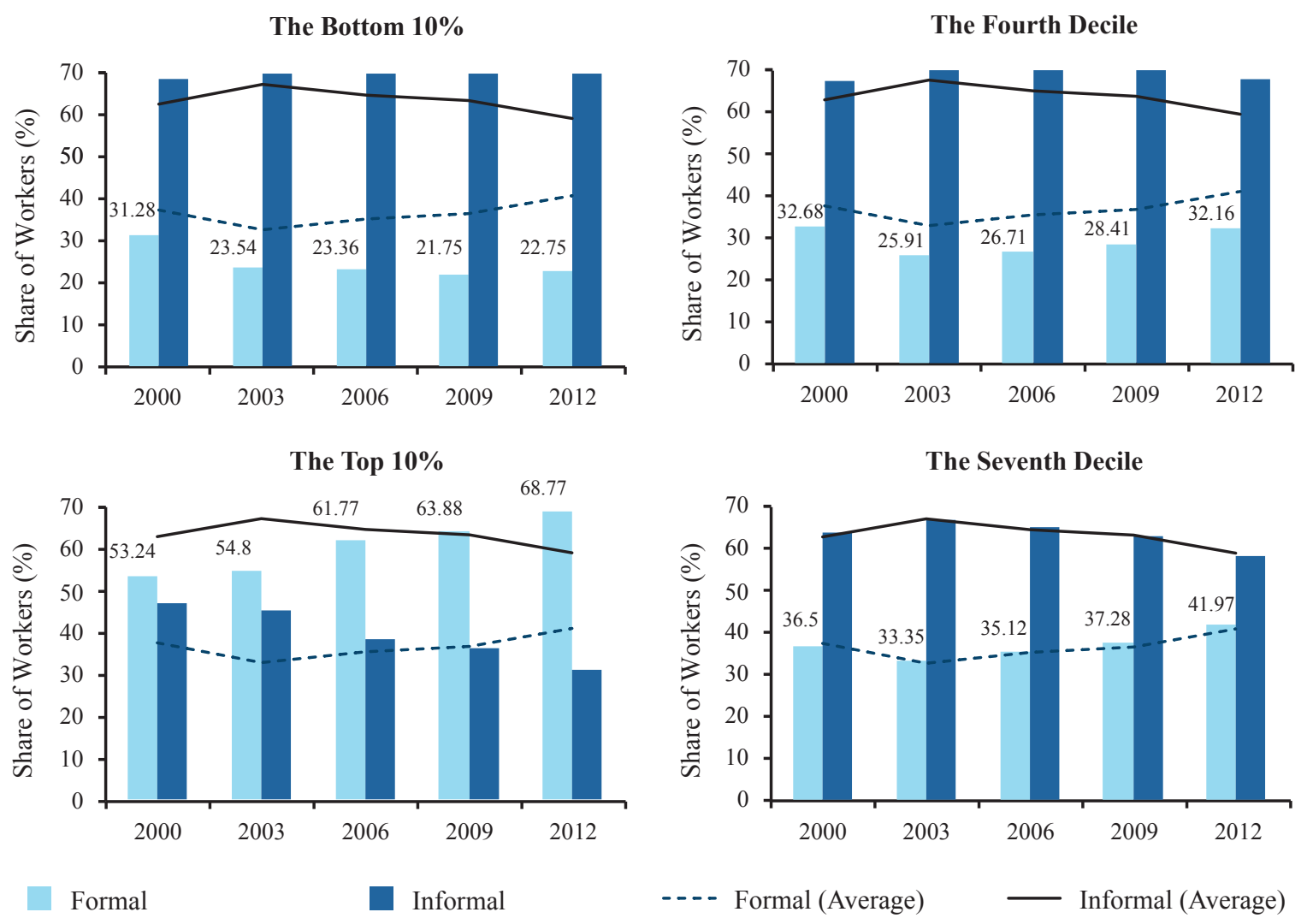

Note: TNP2K calculations based on Susenas rounds. Survey weights applied.

Table 17 shows sector statistics along the wealth distribution for 2012 by gender and area. The findings suggest that very similar patterns exist along the wealth distribution between men and women as well as between rural and urban areas. In all cases, higher welfare levels are clearly associated with higher levels of formal employment, although as discussed above, the relative role of the formal sector differs. 
Table 17: Proportion of Workers by Sector's Formality, Gender, and Area (2012)

\begin{tabular}{llcccc}
\multicolumn{1}{r}{ Sector Formality } & Total (\%) & $\begin{array}{c}\text { Male } \\
(\%)\end{array}$ & $\begin{array}{c}\text { Female } \\
(\%)\end{array}$ & $\begin{array}{c}\text { Urban } \\
(\%)\end{array}$ & $\begin{array}{c}\text { Rural } \\
(\%)\end{array}$ \\
\hline Decile 1 & & & & & \\
Formal & 22.75 & 24.86 & 19.20 & 36.43 & 15.55 \\
\hline Informal & 77.25 & 75.14 & 80.80 & 63.57 & 84.45 \\
\hline Decile 4 & & & & & \\
Formal & 32.16 & 35.60 & 26.12 & 47.95 & 21.46 \\
\hline Informal & 67.84 & 64.40 & 73.88 & 52.05 & 78.54 \\
\hline Decile 7 & & & & & \\
Formal & 41.97 & 46.39 & 34.29 & 55.87 & 29.64 \\
\hline Informal & 58.03 & 53.61 & 65.71 & 44.13 & 70.36 \\
\hline Decile 10 & & & & & \\
Formal & 68.77 & 70.90 & 65.63 & 74.45 & 47.01 \\
\hline Informal & 31.23 & 29.10 & 34.37 & 25.55 & 52.99 \\
\hline Average (all deciles) & & & & & \\
Formal & 40.93 & 44.08 & 35.66 & 57.25 & 25.82 \\
\hline Informal & 59.07 & 55.92 & 64.34 & 42.75 & 74.18 \\
\hline
\end{tabular}

Note: TNP2K calculations based on Susenas rounds. Survey weights applied.

\section{Employment Differences between Working Poor and Working Nonpoor}

Notable differences exist in the sector of employment (1-digit industry level ${ }^{11}$ ) between the working poor and the working nonpoor. In line with the previous findings that the working poor are increasingly more likely to be in rural Indonesia, we found that a large share of the working poor are employed in the agricultural sector (table 18 and figures 26 and 27). Likewise, we observed a relative shift away from agriculture in line with strong job creation in urban areas. In 2000 the agricultural sector comprised about $44.1 \%$ of the entire labour force, whereas in 2012 , its share decreased to $34.1 \%$. However, agriculture, especially for the poor, has remained the main sector of employment in Indonesia. In contrast to the agricultural sector, we found that better-off workers are more likely to be employed in the finance, trade/ retail, and public sectors. However, it is important to note that a lot of variation exists within each of these sectors. For instance, a significant share of the richest workers (decile 10) belong to the agriculture sector; at the same time, many workers in the trade/retail sector form part of the working poor.

\footnotetext{
11 As common in most countries of the world, Statistics Indonesia has developed a coding structure that attempts to classify all forms of economic activity - including government and nonprofit entities - in order to provide a common statistical and conceptual framework for data collection and analysis. The 1-digit classification assigns all types of economic activities uniquely into 1 of 10 possible economic sectors. For more information, please see 'Standard Industrial Classification System (SIC)' at http://www.referenceforbusiness.com/encyclopedia/Sel-Str/Standard-Industrial-Classification-System-SIC. html\#ixzz3AAIt1tZz.
} 
Table 18: Proportion of Workers by Sectors (2000-12)

\begin{tabular}{|c|c|c|c|c|c|}
\hline Proportion of Workers by Sectors & $\begin{array}{l}2000 \\
(\%)\end{array}$ & $\begin{array}{l}2003 \\
(\%)\end{array}$ & $\begin{array}{l}2006 \\
(\%)\end{array}$ & $\begin{array}{c}2009 \\
(\%)\end{array}$ & $\begin{array}{l}2012 \\
(\%)\end{array}$ \\
\hline \multicolumn{6}{|l|}{ Decile 1} \\
\hline Agriculture, forestry, hunting, and fishery & 58.57 & 62.56 & 58.96 & 59.11 & 55.76 \\
\hline Mining and quarrying & 0.74 & 0.79 & 0.98 & 1.19 & 1.24 \\
\hline Manufacturing industry & 11.64 & 9.89 & 10.56 & 9.93 & 11.43 \\
\hline Electricity, gas, and water & 0.06 & 0.10 & 0.13 & 0.16 & 0.14 \\
\hline Construction & 4.75 & 4.28 & 6.58 & 5.04 & 8.20 \\
\hline Wholesale trade, retail trade, restaurants, and hotels & 13.07 & 11.41 & 10.78 & 10.86 & 10.60 \\
\hline Transportation, storage, and communications & 4.59 & 4.25 & 4.55 & 3.20 & 3.17 \\
\hline $\begin{array}{l}\text { Financing, insurance, real estate, and business } \\
\text { services }\end{array}$ & 0.43 & 0.31 & 0.42 & 0.36 & 0.18 \\
\hline Public servants, civil, social, and personal services & 6.16 & 6.24 & 6.92 & 8.44 & 8.28 \\
\hline Other & $\mathrm{n} / \mathrm{a}$ & 0.17 & 0.13 & 1.71 & 1.00 \\
\hline \multicolumn{6}{|l|}{ Decile 4} \\
\hline Agriculture, forestry, hunting, and fishery & 51.96 & 54.94 & 48.78 & 46.14 & 41.16 \\
\hline Mining and quarrying & 0.64 & 0.75 & 1.12 & 1.18 & 1.65 \\
\hline Manufacturing industry & 12.54 & 10.95 & 13.16 & 11.73 & 13.21 \\
\hline Electricity, gas, and water & 0.13 & 0.15 & 0.21 & 0.26 & 0.25 \\
\hline Construction & 4.00 & 4.33 & 5.87 & 5.40 & 7.15 \\
\hline Wholesale trade, retail trade, restaurants, and hotels & 17.59 & 15.69 & 16.23 & 17.51 & 19.43 \\
\hline Transportation, storage, and communications & 5.03 & 5.10 & 5.55 & 4.44 & 5.07 \\
\hline $\begin{array}{l}\text { Financing, insurance, real estate, and business } \\
\text { services }\end{array}$ & 0.68 & 0.57 & 0.73 & 0.91 & 0.46 \\
\hline Public servants, civil, social, and personal services & 7.43 & 7.44 & 8.20 & 11.08 & 10.57 \\
\hline Other & $\mathrm{n} / \mathrm{a}$ & 0.09 & 0.15 & 1.36 & 1.06 \\
\hline \multicolumn{6}{|l|}{ Decile 7} \\
\hline Agriculture, forestry, hunting, and fishery & 42.36 & 45.64 & 37.30 & 33.56 & 31.31 \\
\hline Mining and quarrying & 0.68 & 0.63 & 1.04 & 1.25 & 1.55 \\
\hline Manufacturing industry & 12.54 & 12.31 & 13.68 & 12.61 & 13.36 \\
\hline Electricity, gas, and water & 0.21 & 0.30 & 0.28 & 0.33 & 0.28 \\
\hline Construction & 3.98 & 3.99 & 5.16 & 4.69 & 6.01 \\
\hline Wholesale trade, retail trade, restaurants, and hotels & 21.67 & 19.43 & 22.17 & 23.85 & 23.52 \\
\hline Transportation, storage, and communications & 5.97 & 6.04 & 6.04 & 5.01 & 5.11 \\
\hline $\begin{array}{l}\text { Financing, insurance, real estate, and business } \\
\text { services }\end{array}$ & 1.08 & 1.08 & 1.18 & 1.63 & 0.96 \\
\hline Public servants, civil, social, and personal services & 11.51 & 10.48 & 12.98 & 15.72 & 16.98 \\
\hline Other & $\mathrm{n} / \mathrm{a}$ & 0.09 & 0.16 & 1.34 & 0.92 \\
\hline
\end{tabular}


Table 18: Proportion of Workers by Sectors (2000-12) [continued]

\begin{tabular}{|c|c|c|c|c|c|}
\hline Proportion of Workers by Sectors & $\begin{array}{l}2000 \\
(\%)\end{array}$ & $\begin{array}{l}2003 \\
(\%)\end{array}$ & $\begin{array}{l}2006 \\
(\%)\end{array}$ & $\begin{array}{r}2009 \\
(\%)\end{array}$ & $\begin{array}{l}2012 \\
(\%)\end{array}$ \\
\hline \multicolumn{6}{|l|}{ Decile 10} \\
\hline Agriculture, forestry, hunting, and fishery & 20.09 & 22.29 & 13.24 & 10.72 & 9.73 \\
\hline Mining and quarrying & 1.20 & 1.33 & 1.29 & 1.34 & 1.65 \\
\hline Manufacturing industry & 12.52 & 14.26 & 12.92 & 10.64 & 12.62 \\
\hline Electricity, gas, and water & 0.50 & 0.49 & 0.58 & 0.83 & 0.71 \\
\hline Construction & 3.11 & 3.10 & 3.18 & 3.19 & 3.86 \\
\hline Wholesale trade, retail trade, restaurants, and hotels & 28.64 & 25.24 & 27.79 & 27.42 & 26.40 \\
\hline Transportation, storage, and communications & 5.60 & 6.00 & 5.50 & 4.23 & 5.22 \\
\hline $\begin{array}{l}\text { Financing, insurance, real estate, and business } \\
\text { services }\end{array}$ & 4.02 & 3.77 & 5.38 & 6.14 & 4.04 \\
\hline Public servants, civil, social, and personal services & 24.32 & 23.44 & 29.95 & 33.41 & 34.32 \\
\hline Other & $\mathrm{n} / \mathrm{a}$ & 0.08 & 0.18 & 2.08 & 1.44 \\
\hline \multicolumn{6}{|l|}{ Average (all deciles) } \\
\hline Agriculture, forestry, hunting, and fishery & 44.10 & 47.46 & 39.80 & 37.44 & 34.13 \\
\hline Mining and quarrying & 0.77 & 0.83 & 1.08 & 1.24 & 1.46 \\
\hline Manufacturing industry & 12.30 & 11.83 & 13.16 & 11.58 & 12.71 \\
\hline Electricity, gas, and water & 0.20 & 0.25 & 0.31 & 0.38 & 0.32 \\
\hline Construction & 4.00 & 4.00 & 5.22 & 4.71 & 6.51 \\
\hline Wholesale trade, retail trade, restaurants, and hotels & 20.25 & 17.97 & 19.75 & 20.69 & 20.90 \\
\hline Transportation, storage, and communications & 5.39 & 5.38 & 5.69 & 4.50 & 4.70 \\
\hline $\begin{array}{l}\text { Financing, insurance, real estate, and business } \\
\text { services }\end{array}$ & 1.34 & 1.16 & 1.58 & 1.91 & 1.14 \\
\hline Public servants, civil, social, and personal services & 11.64 & 11.01 & 13.27 & 16.03 & 17.07 \\
\hline Other & $\mathrm{n} / \mathrm{a}$ & 0.10 & 0.14 & 1.51 & 1.06 \\
\hline
\end{tabular}

Note: TNP2K calculations based on Susenas rounds. Survey weights applied. 
Figure 26: Proportion of Workers by Sectors (2012)

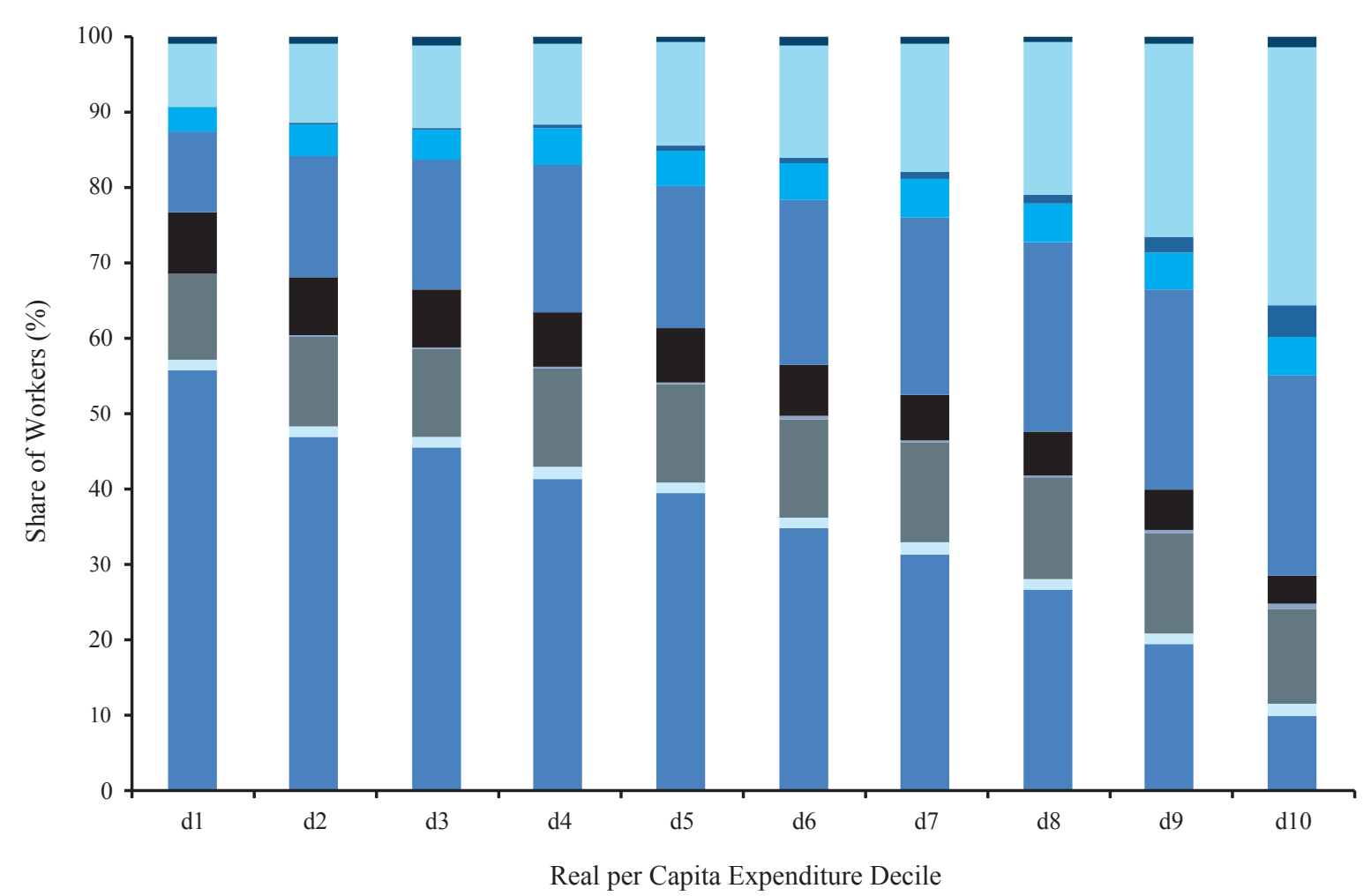

Others (\%)

Community, social, and personal services (\%)

Financing, insurance, real estate and business services (\%)

Transportation, storage, and communications (\%)

Wholesale trade, retail trade, restaurants and hotels (\%)
Construction (\%)

Electricity, gas, and water (\%)

Manufacturing industry (\%)

Mining and quarrying (\%)

Agriculture, forestry, hunting and fishery (\%)

Note: TNP2K calculations based on Susenas rounds. Survey weights applied. 
Figure 27: Proportion of Workers by Sectors (2000-12)

The Bottom 10\%

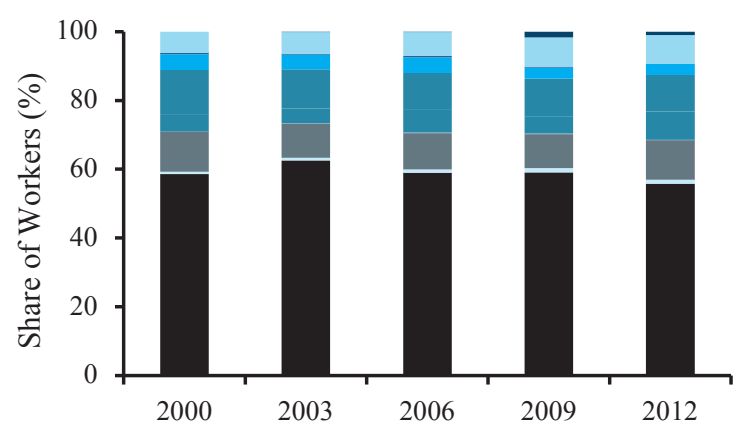

The Top 10\%

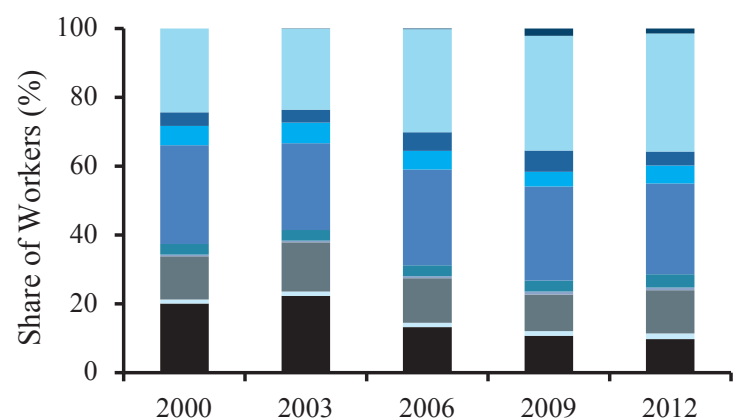

Others $(\%)$

Public servants, civil, social, and personal services (\%)

Financing, insurance, real estate and business services (\%)

Transportation, storage, and communications (\%)

Wholesale trade, retail trade, restaurants and hotels (\%)
The Fourth Decile

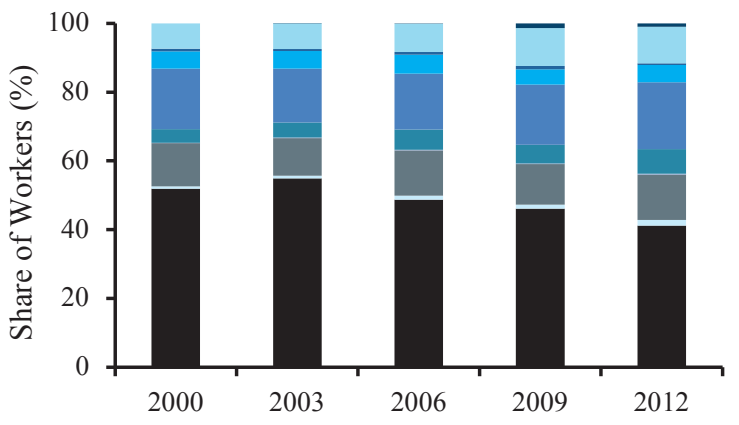

The Seventh Decile

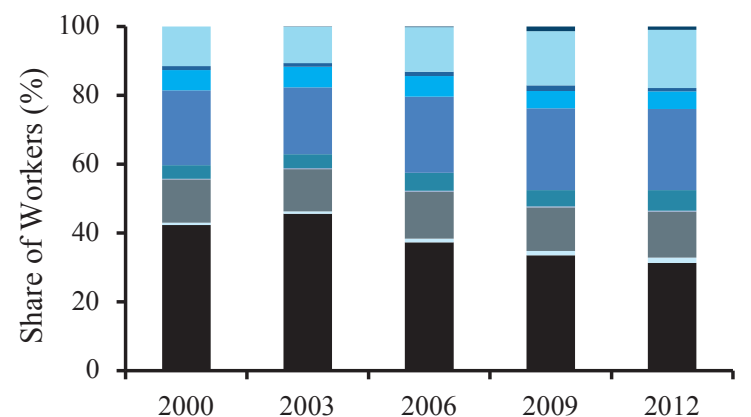

Construction (\%)

Electricity, gas, and water (\%)

Manufacturing industry (\%)

Mining and quarrying (\%)

Agriculture, forestry, hunting and fishery (\%)

Note: TNP2K calculations based on Susenas rounds. Survey weights applied. 


\section{Summary}

This report examines the links between poverty and the labour market in Indonesia covering the period 2000-12, a period accompanied by high economic growth rates, creation of millions of new jobs, and a strong decrease in poverty rates.

Despite significant achievements in recent years, many Indonesians continue to live in poverty despite having a job and working many hours each week. In fact, this report finds that the poor are as likely as the nonpoor to work, both at the extensive (labour force participation) and at the intensive (number of days and number of hours) margins. The reason for being poor despite being employed is therefore largely driven by other factors. In terms of household structure, clear evidence exists that the working poor need to share their income among a wider group (larger household size), especially economically nonactive persons (young children and the elderly). The working poor live in households with a higher dependency ratio, which contributes to their being/becoming working poor. Furthermore, the working poor are more likely to be casual workers and are more likely to work in employment that provides lower hourly wages and in several cases is unpaid (ILO 2013).

Significant gender differences exist in the Indonesian labour market. Men show higher labour LFPRs and are more likely to work more hours compared with women (conditional on having a job). However, we did not observe strong gender differences between men and women who are working with respect to their poverty status. Across the entire wealth distribution, we found that the men to women employment ratios in each wealth decile is largely constant.

Economic growth in Indonesia during 2000-12 has not been even throughout the country; urban areas create significantly more jobs and more full-time employment opportunities. In line with this general trend, we observed that the working poor are increasingly characterised by their location in rural areas. Likewise, we observed that the majority of the working poor are working in the agricultural sector. In contrast, we found that workers in the finance, trade, and public sectors are the least likely to be or become poor. Similarly, we found that the working poor are predominantly and increasingly (in relative terms) concentrated in the informal sector of the economy.

An important finding concerns the role of education in the likelihood of being poor or nonpoor. Our results suggest that only higher secondary and tertiary education seems to increase the likelihood of meaningfully protecting against poverty. Among all other education levels (incomplete primary, completed primary, and completed lower secondary education), we found that these workers tend over time to increasingly concentrate in the poorer wealth deciles. 


\section{References}

Alatas, Vivi, Purnamasari, R. and M. Wai-Poi. "Targeting of the poor and vulnerable." In Employment, Living Standards and Poverty in Contemporary Indonesia, edited by Chris Manning and Sudarno Sumarto, Singapore: ISEAS publishing, 2012.

Alisjahbana, A. S., and C. Manning. 2006. 'Labour Market Dimensions of Poverty in Indonesia'. Bulletin of Indonesian Economic Studies 42(2): 235-61.

Aswicahyono, H., H. Hill, and D. Narjoko. 2011. 'Indonesian Industrialization: Jobless Growth?' in Employment, Living Standards, and Poverty in Contemporary Indonesia edited by Chris Manning and Sudarno Sumarto (Singapore: Institute of Southeast Asian Studies), 113-33.

BPS (Statistics Indonesia). 2013a. Data Strategis BPS (Strategic Data BPS). Jakarta: BPS.

BPS. 2013b. Proyeksi Penduduk Indonesia: 2010-2035: Indonesia Population Projection, 2010-2035). Jakarta: BPS.

Di Gropello, E., A. Kruse, and P. Tandon. 2011. Skills for the Labour Market in Indonesia: Trends in Demand, Gaps, and Supply. Washington, DC: World Bank.

Duflo, E. 2001. 'Schooling and Labour Market Consequences of School Construction in Indonesia: Evidence from an Unusual Policy Experiment'. American Economic Review 91(4): 795-813.

Duflo, E. 2004. 'The Medium-Run Effects of Educational Expansion: Evidence from a Large School Construction Program in Indonesia'. Journal of Development Economics 74(1): 163-97.

Fahmi, M. and B. Satriatna. 2013. 'Development in Education Sector: Are the Poor Catching Up?'. Working Paper in Economics and Development Studies No. 201315. Bandung, Indonesia: Department of Economics, Padjadjaran University.

Huynh, P., and S. Kapsos. 2013. 'Economic Class and Labour Market Inclusion: Poor and Middle Class Workers in Developing Asia and the Pacific'. ILO Asia-Pacific Working Paper Series. Bangkok: International Labour Organization.

ILO (International Labour Organization). 2011. Labour and Social Trends in Indonesia 2010: Translating Economic Growth into Employment Creation. Jakarta: ILO.

ILO. 2012. Global Employment Trends 2012: Preventing a Deeper Jobs Crisis. Geneva: ILO.

ILO. 2013. Labour and Social Trends in Indonesia 2013: Reinforcing the Role of Decent Work in Equitable Growth. Jakarta: ILO.

Magruder, J. R. 2013. 'Can Minimum Wages Cause a Big Push? Evidence from Indonesia'. Journal of Development Economics 100(1): 48-62. 
Oberman, R., R. Dobbs, A. Budiman, F. Thompson, and M. Rossé. 2012. The Archipelago Economy: Unleashing Indonesia's Potential. Jakarta: McKinsey Global Institute.

OECD (Organisation for Economic Cooperation and Development). 2013. Activation Strategies for Stronger and More Inclusive Labour Markets in G20 Countries: Key Policy Challenges and Good Practices. Paris: OECD.

Priebe, J. 2014. 'Official Poverty Measurement in Indonesia since 1984: A Methodological Review'. Bulletin of Indonesian Economic Studies 50(2): 185-205.

Priebe, J., and F. Howell. 2014. Old-Age Poverty in Indonesia: Empirical Evidence and Policy Options: A Role for Social Pensions. Jakarta: Tim Nasional Percepatan Penanggulangan Kemiskinan (TNP2K).

Purnagunawan, R. M., and V. Firmana. 2013. 'Labour Market Development in Indonesia: Has It Been for All?'. Working Paper in Economics and Development Studies No. 201317. Bandung, Indonesia: Department of Economics, Padjadjaran University.

Purnastuti, L., P. W. Miller, and R. Salim. 2013. 'Declining Returns to Education: Evidence for Indonesia'. Bulletin of Indonesian Economic Studies 49(2): 213-36.

Smith, J. P., D. Thomas, E. Frankenberg, K. Beegle, and G. Teruel. 2002. 'Wages, Employment, and Economic Shocks: Evidence from Indonesia'. Journal of Population Economics 15(1): 161-93.

Suharti. 2013. 'Trends in Education in Indonesia' in Education in Indonesia edited by D. Suryadarma and G. W. Jones (Singapore: Institute of Southeast Asian Studies), 15-51.

Suryadarma, D., A. Suryahadi, and S. Sumarto. 2007. 'Measuring Unemployment in Developing Countries: The Case of Indonesia'. Labour 21(3): 541-62.

World Bank. 2010. Indonesia Jobs Report: Towards Better Jobs and Security for All. Jakarta: World Bank.

World Bank. 2012. Protecting Poor and Vulnerable Households in Indonesia. Washington, DC: World Bank. Vols. 1 and 2. Available at http://documents.worldbank.org/curated/en/2012/02/15879721/ protecting-poor-vulnerable-households-indonesia.

World Bank. 2012. Targeting poor and vulnerable households in Indonesia. Public expenditure review (PER). Washington, DC: World Bank. Available at http://documents.worldbank.org/curated/ en/2012/01/15879773/targeting-poor-vulnerable-households-indonesia.

World Bank. 2013. World Development Report: Jobs. Washington, DC: World Bank. 


\section{Appendix}

Table A1: Labour Market Indicators according to Statistics Indonesia (2000-12)

\begin{tabular}{|c|c|c|c|c|c|c|c|c|c|c|}
\hline $\begin{array}{c}\text { Labour } \\
\text { Market } \\
\text { Indicators }\end{array}$ & $2004 *$ & $2005 * *$ & 2006 & 2007 & 2008 & 2009 & 2010 & 2011 & 2012 & 2013 \\
\hline $\begin{array}{l}\text { Open } \\
\text { inemployment } \\
\text { ate }(\%)\end{array}$ & 9.86 & 11.24 & 10.28 & 9.11 & 8.39 & 7.87 & 7.275 & 7.14 & 6.32 & 5.92 \\
\hline $\begin{array}{l}\text { abour force } \\
\text { articipation } \\
\text { ate }(\%)\end{array}$ & 67.55 & 66.79 & 66.16 & 66.99 & 67.18 & 67.23 & 67.72 & 68.34 & 67.88 & 69.21 \\
\hline
\end{tabular}

* Figures are yearly.

** Figures drawn from the November round of Sakernas.

Note: Statistics taken from Statistics Indonesia (2013b). Figures drawn from August round of Sakernas, unless otherwise noted.

Table A2: Labour Market Indicators by Provinces (2000)

\begin{tabular}{|c|c|c|c|c|c|c|c|}
\hline \multirow[b]{2}{*}{ Province } & \multicolumn{7}{|c|}{ Labour Market Indicators (2000) } \\
\hline & $\begin{array}{c}\text { Working } \\
\text { Age Population }\end{array}$ & $\begin{array}{l}\text { Labour } \\
\text { Force }\end{array}$ & $\begin{array}{c}\text { Labour Force } \\
\text { Participation Rate } \\
(\%)\end{array}$ & $\begin{array}{c}\text { Employment } \\
\text { Rate } \\
(\%)\end{array}$ & $\begin{array}{c}\text { Full-time } \\
\text { Employment } \\
(\%)\end{array}$ & $\begin{array}{l}\text { Underemployment } \\
\text { Rate } \\
(\%)\end{array}$ & $\begin{array}{c}\text { Unemployment } \\
\text { Rate } \\
(\%)\end{array}$ \\
\hline Bali & $2,341,320$ & $1,718,515$ & 73.4 & 97.70 & 62.71 & 34.99 & 2.30 \\
\hline Bengkulu & 922,554 & 645,304 & 69.95 & 98.30 & 63.22 & 35.08 & 1.70 \\
\hline DI Yogyakarta & $2,454,761$ & $1,709,467$ & 69.64 & 96.42 & 64.88 & 31.53 & 3.58 \\
\hline DKI Jakarta & $6,347,544$ & $3,623,851$ & 57.09 & 90.47 & 80.58 & 9.89 & 9.53 \\
\hline Jambi & $1,616,822$ & 977,877 & 60.48 & 97.05 & 56.91 & 40.13 & 2.95 \\
\hline Jawa Barat & $30,142,693$ & $17,488,340$ & 58.02 & 93.19 & 60.94 & 32.25 & 6.81 \\
\hline Jawa Tengah & $22,077,833$ & $14,950,433$ & 67.72 & 95.84 & 58.97 & 36.87 & 4.16 \\
\hline Jawa Timur & $25,572,183$ & $16,408,813$ & 64.17 & 96.97 & 54.69 & 42.29 & 3.03 \\
\hline Kalimantan Barat & $2,446,814$ & $1,727,811$ & 70.61 & 97.03 & 57.18 & 39.84 & 2.97 \\
\hline Kalimantan Selatan & $2,050,338$ & $1,390,727$ & 67.83 & 97.58 & 57.48 & 40.10 & 2.42 \\
\hline Kalimantan Tengah & $1,195,780$ & 801,933 & 67.06 & 97.47 & 62.91 & 34.55 & 2.53 \\
\hline Kalimantan Timur & $1,655,416$ & $1,056,827$ & 63.84 & 95.61 & 64.76 & 30.85 & 4.39 \\
\hline Lampung & $4,469,258$ & $2,933,637$ & 65.64 & 97.66 & 58.52 & 39.14 & 2.34 \\
\hline Maluku Utara & $1,291,959$ & 973,363 & 75.34 & 98.14 & 40.51 & 57.63 & 1.86 \\
\hline Nusa Tenggara Barat & $2,504,795$ & $1,651,111$ & 65.92 & 96.56 & 47.71 & 48.85 & 3.44 \\
\hline Nusa Tenggara Timur & $2,480,033$ & $1,835,543$ & 74.01 & 98.63 & 44.16 & 54.47 & 1.37 \\
\hline Riau & $3,169,272$ & $1,856,996$ & 58.59 & 94.10 & 63.62 & 30.48 & 5.90 \\
\hline Sulawesi Selatan & $5,323,302$ & $2,898,088$ & 54.44 & 96.74 & 50.58 & 46.16 & 3.26 \\
\hline Sulawesi Tengah & $1,370,876$ & 863,917 & 63.02 & 97.83 & 57.11 & 40.72 & 2.17 \\
\hline Sulawesi Tenggara & $1,106,027$ & 684,083 & 61.85 & 96.91 & 50.94 & 45.97 & 3.09 \\
\hline Sulawesi Utara & $2,046,692$ & $1,149,804$ & 56.18 & 94.62 & 53.95 & 40.67 & 5.38 \\
\hline Sumatera Barat & $2,839,710$ & $1,685,240$ & 59.35 & 96.59 & 54.93 & 41.66 & 3.41 \\
\hline Sumatera Selatan & $5,179,666$ & $3,228,493$ & 62.33 & 97.23 & 58.18 & 39.05 & 2.77 \\
\hline Sumatera Utara & $7,500,505$ & $4,781,502$ & 63.75 & 96.18 & 61.82 & 34.36 & 3.82 \\
\hline
\end{tabular}

Note: TNP2K calculations based on Susenas rounds. Survey weights applied. 
Table A3: Labour Market Indicators by Provinces (2012)

\begin{tabular}{|c|c|c|c|c|c|c|c|}
\hline \multirow[b]{2}{*}{ Province } & \multicolumn{7}{|c|}{ Labour Market Indicators (2012) } \\
\hline & $\begin{array}{l}\text { Working Age } \\
\text { Population } \\
\text { (n) }\end{array}$ & $\begin{array}{l}\text { People in } \\
\text { Labour } \\
\text { Force } \\
\text { (n) }\end{array}$ & $\begin{array}{c}\text { Labour } \\
\text { Force } \\
\text { Participation } \\
\text { Rate } \\
(\%)\end{array}$ & $\begin{array}{c}\text { Employment } \\
\text { Rate } \\
(\%)\end{array}$ & $\begin{array}{c}\text { Full-time } \\
\text { employment } \\
(\%)\end{array}$ & $\begin{array}{c}\text { Underemployment } \\
\text { Rate } \\
(\%)\end{array}$ & $\begin{array}{c}\text { Unemployment } \\
\text { Rate } \\
(\%)\end{array}$ \\
\hline Bali & $3,016,258$ & $2,342,749$ & 77.67 & 99.38 & 67.62 & 31.76 & 0.62 \\
\hline Banten & $7,933,476$ & $5,078,138$ & 64.01 & 93.93 & 72.40 & 21.53 & 6.07 \\
\hline Bengkulu & $1,230,910$ & 865,944 & 70.35 & 98.12 & 64.13 & 33.99 & 1.88 \\
\hline DI Yogyakarta & $2,763,154$ & $1,963,716$ & 71.07 & 98.28 & 72.26 & 26.02 & 1.72 \\
\hline DKI Jakarta & $7,532,550$ & $5,133,507$ & 68.15 & 94.67 & 84.08 & 10.59 & 5.33 \\
\hline Gorontalo & 741,479 & 494,921 & 66.75 & 98.55 & 68.82 & 29.72 & 1.45 \\
\hline Jambi & $2,265,481$ & $1,517,566$ & 66.99 & 98.53 & 56.40 & 42.14 & 1.47 \\
\hline Jawa Barat & $31,638,366$ & $19,854,407$ & 62.75 & 94.97 & 72.39 & 22.58 & 5.03 \\
\hline Jawa Tengah & $23,935,516$ & $16,741,490$ & 69.94 & 96.87 & 69.98 & 26.89 & 3.13 \\
\hline Jawa Timur & $28,598,641$ & $19,711,413$ & 68.92 & 97.97 & 68.33 & 29.64 & 2.03 \\
\hline Kalimantan Barat & $3,044,978$ & $2,204,180$ & 72.39 & 98.32 & 62.84 & 35.48 & 1.68 \\
\hline Kalimantan Selatan & $2,676,100$ & $1,859,463$ & 69.48 & 98.36 & 67.43 & 30.94 & 1.64 \\
\hline Kalimantan Tengah & $1,583,191$ & $1,135,794$ & 71.74 & 97.70 & 63.73 & 33.97 & 2.30 \\
\hline Kalimantan Timur & $2,676,667$ & $1,77,0323$ & 66.14 & 96.13 & 76.01 & 20.12 & 3.87 \\
\hline Kep. Bangka Belitung & 922,858 & 633,084 & 68.60 & 98.80 & 72.71 & 26.09 & 1.20 \\
\hline Kep. Riau & $1,359,786$ & 924,373 & 67.98 & 97.44 & 77.11 & 20.33 & 2.56 \\
\hline Lampung & $5,496,293$ & $3,786,255$ & 68.89 & 97.62 & 60.30 & 37.32 & 2.38 \\
\hline Maluku & $1,042,538$ & 703,100 & 67.44 & 96.78 & 68.82 & 27.96 & 3.22 \\
\hline Maluku Utara & 706,555 & 476,315 & 67.41 & 97.40 & 62.51 & 34.89 & 2.60 \\
\hline $\begin{array}{l}\text { Nanggroe Aceh } \\
\text { Darussalam }\end{array}$ & $3,209,098$ & $1,959,256$ & 61.05 & 95.68 & 56.26 & 39.42 & 4.32 \\
\hline Nusa Tenggara Barat & $3,165,763$ & $2,158,232$ & 68.17 & 98.17 & 58.60 & 39.57 & 1.83 \\
\hline Nusa Tenggara Timur & $3,078,081$ & $2,186,035$ & 71.02 & 98.70 & 55.34 & 43.37 & 1.30 \\
\hline Papua & $2,067,742$ & $1,664,881$ & 80.52 & 97.76 & 58.45 & 39.30 & 2.24 \\
\hline Papua Barat & 543,703 & 360,722 & 66.35 & 95.70 & 65.27 & 30.43 & 4.30 \\
\hline Riau & $3,996,788$ & $2,579,580$ & 64.54 & 97.51 & 61.40 & 36.11 & 2.49 \\
\hline Sulawesi Barat & 792,364 & 539,729 & 68.12 & 99.17 & 54.36 & 44.82 & 0.83 \\
\hline Sulawesi Selatan & $5,673,042$ & $3,479,466$ & 61.33 & 97.36 & 60.83 & 36.54 & 2.64 \\
\hline Sulawesi Tengah & $1,831,175$ & $1,240,165$ & 67.73 & 98.90 & 63.50 & 35.40 & 1.10 \\
\hline Sulawesi Tenggara & $1,514,486$ & $1,032,852$ & 68.20 & 98.99 & 61.62 & 37.37 & 1.01 \\
\hline Sulawesi Utara & $1,678,095$ & $1,039,605$ & 61.95 & 96.29 & 69.03 & 27.26 & 3.71 \\
\hline Sumatera Barat & $3,384,735$ & $2,208,143$ & 65.24 & 97.61 & 64.28 & 33.34 & 2.39 \\
\hline Sumatera Selatan & $5,392,303$ & $3,704,300$ & 68.70 & 98.03 & 59.58 & 38.45 & 1.97 \\
\hline Sumatera Utara & $8,841,440$ & $6,117,535$ & 69.19 & 96.46 & 67.89 & 28.57 & 3.54 \\
\hline
\end{tabular}

Note: TNP2K calculations based on Susenas rounds. Survey weights applied. 
Table A4: The Classification of Sectors by Formality according to Statistics Indonesia

\begin{tabular}{|c|c|c|c|c|c|c|c|c|c|c|}
\hline \multirow{2}{*}{$\begin{array}{c}\text { Main } \\
\text { Employment } \\
\text { Status }\end{array}$} & \multicolumn{10}{|c|}{ Main Occupation } \\
\hline & $\begin{array}{c}\text { Professional, } \\
\text { Technical \& } \\
\text { Related } \\
\text { Workers }\end{array}$ & $\begin{array}{l}\text { Administrative } \\
\text { \& Managerial } \\
\text { Workers }\end{array}$ & $\begin{array}{c}\text { Clerical } \\
\text { \& Related } \\
\text { Workers }\end{array}$ & $\begin{array}{c}\text { Sales } \\
\text { Workers }\end{array}$ & $\begin{array}{l}\text { Services } \\
\text { Workers }\end{array}$ & $\begin{array}{l}\text { Agricultural } \\
\text { Workers }\end{array}$ & $\begin{array}{l}\text { Production } \\
\text { Workers }\end{array}$ & Operators & Labourers & Others \\
\hline Self-employed & $\mathrm{F}$ & $\mathrm{F}$ & F & INF & INF & INF & INF & INF & INF & INF \\
\hline $\begin{array}{l}\text { Self-employed assisted } \\
\text { by family or temporary } \\
\text { worker }\end{array}$ & $\mathrm{F}$ & F & $\mathrm{F}$ & $\mathrm{F}$ & F & INF & $\mathrm{F}$ & $\mathrm{F}$ & $\mathrm{F}$ & INF \\
\hline Employer & $\mathrm{F}$ & F & $\mathrm{F}$ & $\mathrm{F}$ & F & $\mathrm{F}$ & $\mathrm{F}$ & $\mathrm{F}$ & $\mathrm{F}$ & $\mathrm{F}$ \\
\hline Employee & $\mathrm{F}$ & $\mathrm{F}$ & $\mathrm{F}$ & $\mathrm{F}$ & F & $\mathrm{F}$ & $\mathrm{F}$ & $\mathrm{F}$ & $\mathrm{F}$ & $\mathrm{F}$ \\
\hline $\begin{array}{l}\text { Agricultural freelance } \\
\text { worker }\end{array}$ & $\mathrm{F}$ & $\mathrm{F}$ & $\mathrm{F}$ & INF & INF & INF & INF & INF & INF & INF \\
\hline $\begin{array}{l}\text { Nonagricultural freelance } \\
\text { worker }\end{array}$ & $\mathrm{F}$ & F & $\mathrm{F}$ & INF & INF & INF & INF & INF & INF & INF \\
\hline Unpaid worker & INF & INF & INF & INF & INF & INF & INF & INF & INF & INF \\
\hline
\end{tabular}

Source: Statistics Indonesia classification as cited in ILO (2011).

Note: F: Formal; INF: Informal. 



\title{
TNP2K Working Paper Series
}

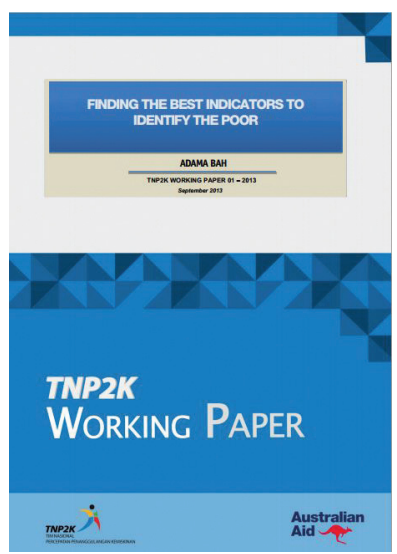

\author{
Working Paper 1 \\ Finding the Best Indicators to Identify the Poor
}

Author : Adama Bah

Proxy-means testing (PMT) is a method used to assess household or individual welfare level based on a set of observable indicators. The accuracy, and therefore usefulness of PMT relies on the selection of indicators that produce accurate predictions of household welfare. In this paper the author proposes a method to identify indicators that are robustly and strongly correlated with household welfare, measured by per capita consumption. From an initial set of 340 candidate variables drawn from the Indonesian Family Life Survey, the author identifies the variables that contribute most significantly to model predictive performance and that are therefore desirable to be included in a PMT formula. These variables span the categories of household private asset holdings, access to basic domestic energy, education level, sanitation and housing. A comparison of the predictive performance of PMT formulas including 10, 20 and 30 of the best predictors of welfare shows that leads to recommending formulas with 20 predictors. Such parsimonious models have similar predictive performance as the PMT formulas currently used in Indonesia, although these latter are based on models of 32 variables on average.

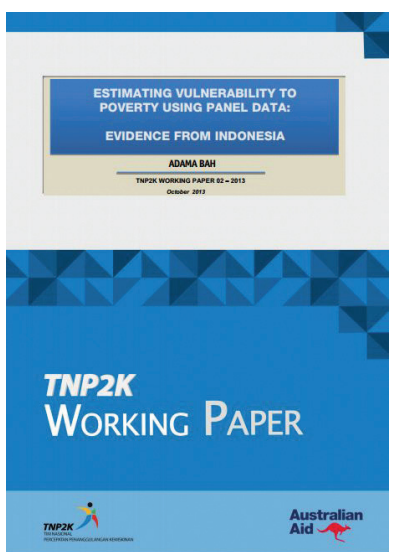

Working Paper 2

Estimating Vulnerability to Poverty using Panel Data: Evidence from Indonesia

Author : Adama Bah

Traditional poverty measures fail to indicate the degree of risk of becoming or remaining poor that households are confronted to. They can therefore be misleading in the context of implementing poverty reduction policies. In this paper the author proposes a method to estimate an index of ex ante vulnerability to poverty, defined as the probability of being poor in the (near) future given current observable characteristics, using panel data. This method relies on the estimation of the expected mean and variance of future consumption conditional on current consumption and observable characteristics. It generates a vulnerability index, or predicted probability of future poverty, which performs well in predicting future poverty, including out of sample. About $80 \%$ of households with a 2000 vulnerability index of $100 \%$ are actually poor in 2007. This approach provides information on the population groups that have a high probability of becoming or remaining poor in the future, whether currently poor or not. It is therefore useful to complement traditional poverty measures such as the poverty headcount, in particular for the design and planning of poverty reduction policies. 


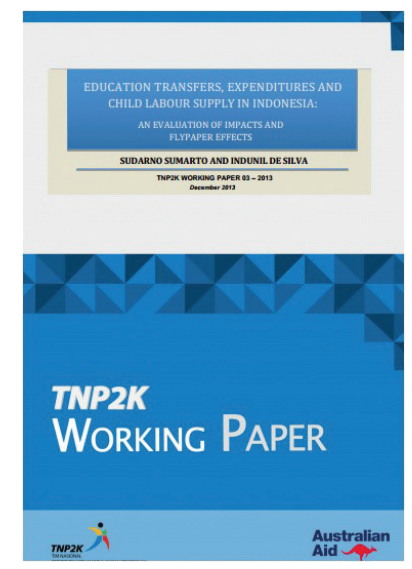

\title{
Working Paper 3 \\ Education Transfer, Expenditures And Child Labour Supply in Indonesia: An Evaluation of Impacts And Flypaper Effects
}

\author{
Author : Sudarno Sumarto and Indunil De Silva
}

In this paper the authors investigate how the receipt of educational transfers, scholarships and related assistance programmes affects the labour supply of children and the marginal spending behaviour of households on children's educational goods. The authors use a nationally representative household survey of unusual scope and richness from Indonesia. They found strong evidence of educational cash transfers and related assistance programmes significantly decreasing the time spent by children on income-generating activities in Indonesia. Households receiving educational transfers, scholarships and assistance were also found to spend more at the margin on voluntary educational goods. These results were stronger on children living in poor families. The findings of this study lend support to the growing view in the literature that educational transfers, scholarships and related assistance can actually have a positive impact on economic development by increasing the level of investment in human capital. The results are particularly relevant for understanding the role of cash transfers and education assistance in middle-income countries, where enrolment rates are already at satisfactory levels, but the challenge is to keep post-primary students in school. Finally, the principal message that emerges from the study is: there are quantitatively non-negligible, average gains from educational transfers and support programmes on household education spending and child labour, especially for the poor.

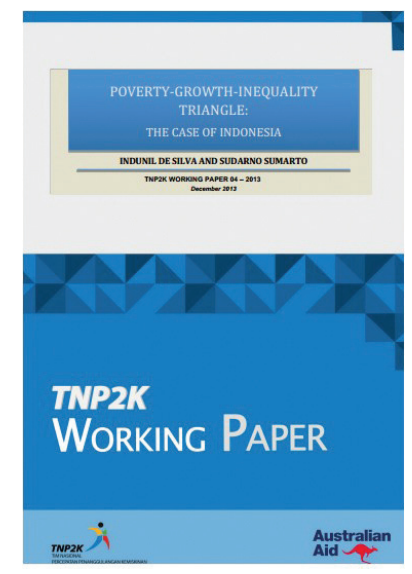

\section{Working Paper 4}

\section{Poverty-Growth-Inequality Triangle: The Case of Indonesia}

Author : Sudarno Sumarto and Indunil De Silva

This paper decomposes changes in poverty into growth and redistribution components, and employs several pro-poor growth concepts and indices to explore the growth, poverty and inequality nexus in Indonesia over the period 2002-2012. The authors find a 'trickledown' situation, which the poor have received proportionately less benefits from growth than the non-poor. All pro-poor measures suggest that economic growth in Indonesia was particularly beneficial for those located at the top of the distribution. Regression-based decompositions suggest that variation in expenditure by education characteristics that persist after controlling for other factors to account for around two-fifths of total household expenditure inequality in Indonesia. If poverty reduction is one of the principal objectives of the Indonesian government, it is essential that policies designed to spur growth also take into account the possible impact of growth on inequality. These findings indicate the importance of a set of super pro-poor policies. Namely, policies that increase school enrolment and achievement, effective family planning programmes to reduce the birth rate and dependency load within poor households, facilitating urban-rural migration and labour mobility, connect leading and lagging regions and granting priorities for specific cohorts (such as children, elderly, illiterate, informal workers and agricultural households) in targeted interventions will serve to simultaneously stem rising inequality and accelerate the pace of economic growth and poverty reduction. 


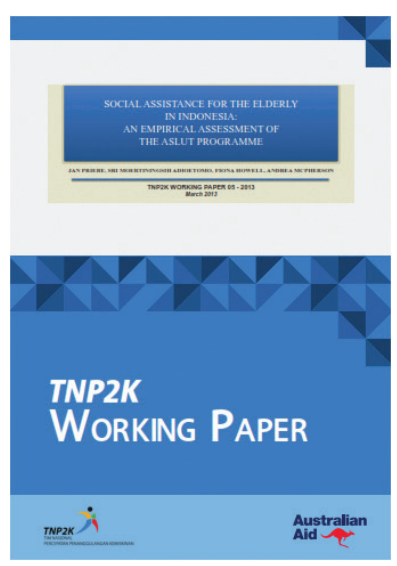

Working Paper 5

Social Assistance for the Elderly in Indonesia: An Empirical

Assessment of the Asistensi Sosial Lanjut Usia Terlantar

Programme*

\section{Asistensi Sosial untuk Usia Lanjut di Indonesia: Kajian Empiris Program Asistensi Sosial Lanjut Usia Terlantar}

Indonesia has undergone a demographic transition since the 1970s that has led to significant changes in the population age structure of the country. Life expectancy at birth increased from 45 years to 67 years. The number of elderly people aged 60 and above rose from about 5 million in 1970 to 18 million in 2010, and is projected to increase to over 71 million in 2050. The economic situation for many elderly persons is precarious. In 2011, 12 percent of older people were below the official poverty line. Older people, especially those in their 70s and those aged 80 and above, have the highest poverty rates among the population groups, 13.3 percent and 16 percent respectively. At the same time, a much greater proportion of the elderly population than officially classified as poor is vulnerable to falling into poverty. Moreover, many of the elderly suffer from poor health and have low literacy levels.

Currently, the coverage of the elderly with the existing formal pension schemes is very low. The Government of Indonesia (GOI) recognizes the gaps in the social insurance schemes and is explicitly taking actions to improve pension coverage. ASLUT, the current social assistance programme targeted directly at poor and neglected elderly, started in 2006 in six provinces reaching 2,500 beneficiaries. It has recently expanded to all 33 provinces and increased the number of recipients to 13,250 in 2011, and 26,500 beneficiaries in 2012. This paper explores the strengths and weaknesses of the coverage provided to the elderly and recommends that the ASLUT programme be developed further to meet the demographic challenges that Indonesia faces.

*This Working Paper has been republished in 2014

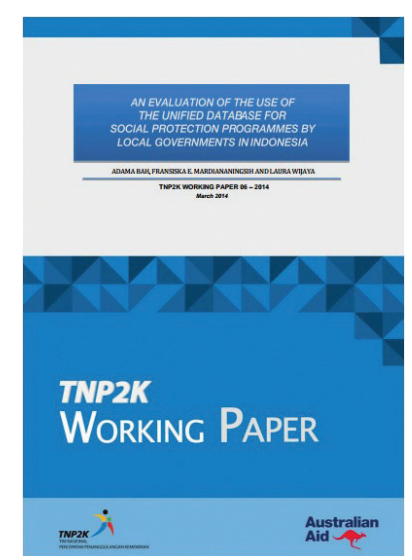

Working Paper 6

An Evaluation of The Use of The Unified Database For Social Protection Programmes By Local Governments In Indonesia

Author : Adama Bah, Fransiska E. Mardiananingsih and Laura Wijaya

The Unified Database for Social Protection Programmes (UDB) contains detailed socioeconomic and demographic information, as well as the names and addresses of the poorest 40 percent of the Indonesian population. Since 2012, the National Team for the Acceleration of Poverty Reduction (TNP2K), which manages the UDB, has provided this data to over 500 local government institutions to facilitate the implementation of local poverty reduction programmes. This paper evaluates the use of the UDB data based on the results of a qualitative assessment of data utilisation at the local level and a self-administered user feedback survey. To improve the cooperation with local governments for increased effectiveness of poverty reduction programmes, the authors' main recommendations are for TNP2K to engage more proactively with the institutions that request data, through (i) regular follow-ups with these institutions, (ii) a broad dissemination of socialisation material explaining the UDB, and (iii) the provision of specialised training on the use of UDB data for the planning and implementation of local programmes. 


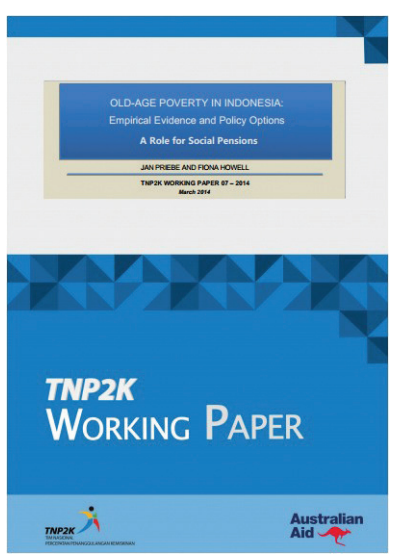

\author{
Working Paper 7 \\ Old-Age Poverty in Indonesia: Empirical Evidence and Policy \\ Options - A Role for Social Pensions \\ Author : Jan Priebe and Fiona Howell
}

Indonesia in 2013 is an ageing society with an elderly population (60+) of approximately 18 million or eight percent of the total population. Due to continuously low fertility levels, lower mortality and higher life expectancy rates, the number of elderly in the country is predicted to increase to more than 80 million individuals by 2050 who will by then constitute about 25 percent of the total population. Considering the rise in its elderly population and the low pension coverage, the Indonesian government has shown strong commitment towards raising the number of elderly who have access to formal pensions. In line with a variety of social welfare laws, the National Security Law (SJSN), declarations under ASEAN and commitments to a comprehensive social protection floor policy, Indonesia has endorsed a mutli-pillar approach to providing income support in old age. However, the current reforms associated with the SJSN Law; aim only at providing income support to the future elderly generation - those working age adults that will retire in 15-40 years. While the success of these reforms needs to be demonstrated, there remains substantial scope to address the need for pension coverage among the current elderly population. Old-Age Poverty in Indonesia: Empirical Evidence and Policy Options - A Role for Social Pensions aims at filling several evidence gaps in the discussion on elderly and old-age poverty in Indonesia. Firstly it provides a detailed and comprehensive picture of the socio-economic circumstances of the current elderly generation. By doing so it provides Indonesia's first nationally representative poverty assessment on the elderly addressing aspects of education, health and remittances as well as poverty measurement. Second, the report outlines Indonesia's legal, political and programme commitments to alleviate old-age poverty and contrasts it with recent international experience on pension reform. This report discusses in particular the benefits of social pensions for Indonesia's elderly, and outlines the pros-and cons of poverty-targeted and universal pension schemes. Finally, the report provides ex-ante simulation results on the poverty and fiscal impacts for selected social pension schemes.

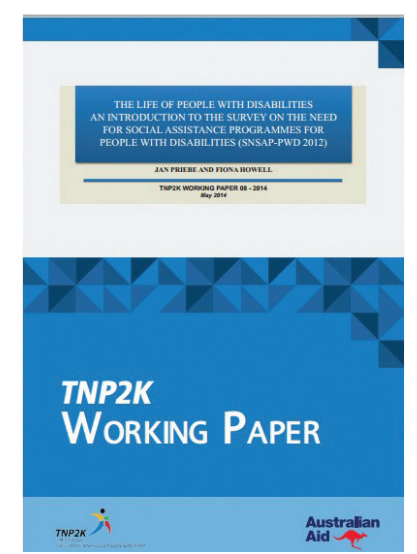

Working Paper 8

The Life of People with Disabilities: An Introduction to the Survey on the Need for Social Assistance Programmes for People with Disabilities

\title{
Author : Jan Priebe and Fiona Howell
}

In 2012, the Demographic Institute of the University of Indonesia conducted on behalf of TNP2K a unique survey on disability that sheds new light on the needs and living conditions of people with disabilities (PWDs) in Indonesia. This new dataset is called the Survey on the Need for Social Assistance Programmes for People with Disabilities (SNSAP-PWD 2012) and is available free of charge from TNP2K and PRSF. This paper provides an introduction into the SNSAP-PWD 2012 by describing its sampling design and the topics covered. 


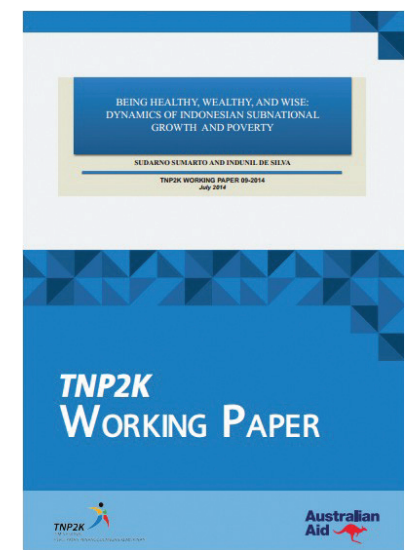

\title{
Working Paper 9 \\ Being Healthy, Wealthy, and Wise: Dynamics of Indonesian \\ Subnational Growth and Poverty
}

\author{
Author : Sudarno Sumarto and Indunil De Silva
}

The aim of this study is twofold. First, despite the vast empirical literature on testing the neoclassical model of economic growth using cross-country data, very few studies exist at the subnational level. The authors attempted to fill this gap by using panel data for 2002-12, a modified neoclassical growth equation, and a dynamic-panel estimator to investigate the effect of both health and education capital on economic growth and poverty at the district level in Indonesia. Second, although most existing cross-country studies tend to concentrate only on education as a measure of human capital, the authors expanded the analysis and probed the effects of health capital as well. To their knowledge, no study has done a direct and comprehensive examination of the impacts of health on growth and poverty at the subnational level. Thus, this study is the first at the subnational level, and the findings will be particularly relevant in understanding the role of both health and education capital in accelerating growth and poverty reduction efforts. The empirical findings are broadly encouraging. First, nullifying any doubts on the reliability of Indonesian subnational data, the results suggest that the neoclassical model augmented by both health and education capital provides a fairly good account of cross-district variation in economic growth and poverty in Indonesia. The authors found that the results on conditional convergence, physical capital investment rate, and population growth confirm the theoretical predictions of the augmented neoclassical model. They also found that both health and education capital had a relatively large and statistically significant positive effect on the growth rate of per capita income. Economic growth was found to play a vital role in reducing Indonesian poverty, reinforcing the importance of attaining higher rates of economic growth. Findings from the poverty-human capital model showed that districts with low levels of education are characterized by higher levels of poverty. Regions with mediocre immunization coverage and greater than average prevalence of waterborne diseases had higher poverty rates and lower output per capita. Similarly, regions with higher numbers of births attended by a skilled birth attendant were associated with lower poverty rates and higher economic output. The results in particular suggest that, in designing policies for growth, human development, and poverty reduction, it is necessary to broaden the concept of human capital to include health as well.

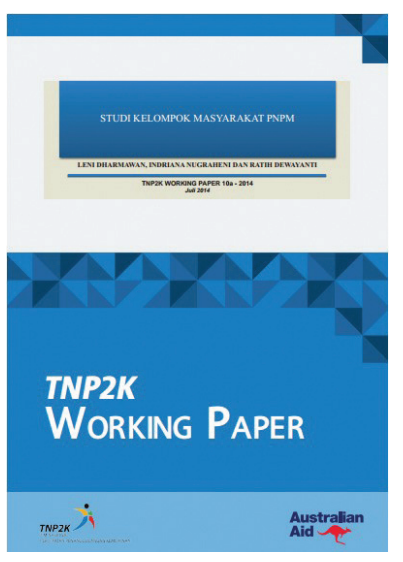

Working Paper 10

Studi Kelompok Masyarakat PNPM

Lampiran Studi Kelompok Masyarakat PNPM

\section{Author : Leni Dharmawan, Indriana Nugraheni dan Ratih Dewayanti, Siti Ruhanawati, Nelti Anggraini}

The PNPM Community Groups study was conducted in four villages and two towns. It demonstrates successful programs but also highlights the limitations in terms of adopting PNPM principles and processes.

There is recognition of the expertise of individual actors in managing the project but their influence is limited since each project has its own rules and tends to form new groups instead of utilizing existing ones. Local governments are not obliged to conform to the principles and processes of PNPM outside of the PNPM program.

Facilitation does not build collective consciousness in the society to correct any imbalances in authority or power among groups within a community. Groups that implement the project need to be integrated into local institutions and there need to be better checks and balances in place to prevent specific groups from becoming dominant. 

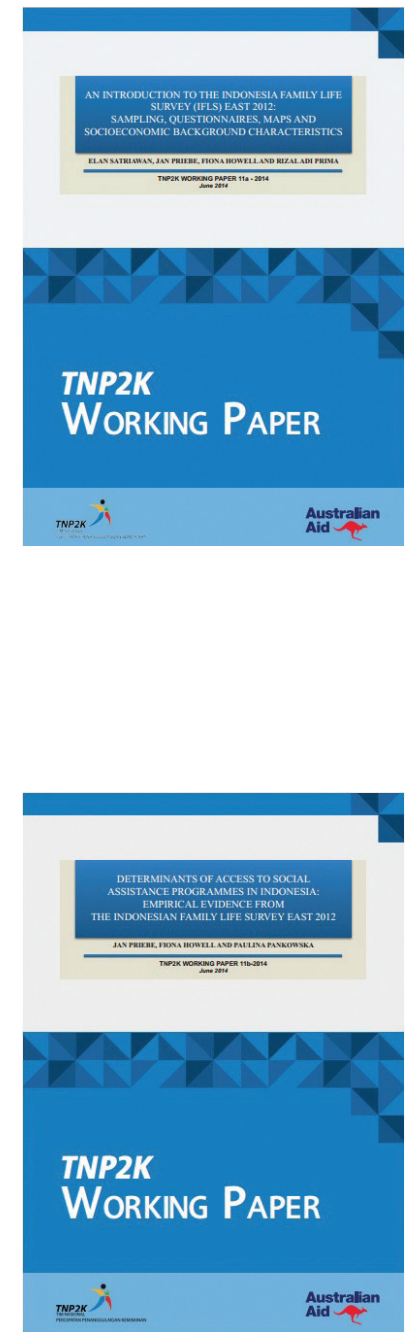

Working Paper 11a

An introduction to the Indonesia Family Life Survey IFLS east 2012 : Sampling Questionnaires Maps and Socioeconomic Background Characteristics

\author{
Author : Elan Satriawan, Jan Priebe, Fiona Howell and Rizal Adi Prima
}

The first round of the Indonesia Family Life Survey (IFLS) East was conducted in Eastern Indonesia in 2012. This paper is intended to provide researchers and policy makers alike an introduction to and brief overview of this new dataset. Topics covered include technical details of survey implementation (sampling procedure, calculation of weights, and field implementation) and a socioeconomic overview using Central Bureau of Statistics (Badan Pusat Statistik or BPS) data and IFLS East data of the prov- inces selected in the region.

\section{Working Paper $11 b$ \\ Determinants of Access to Social Assistance Programmes in Indonesia Empirical Evidence from the Indonesian Family Life Survey East 2012}

\author{
Author :Jan Priebe, Fiona Howell and Paulina Pankowska
}

In the past 15 years, the Government of Indonesia has implemented a variety of social assistance programmes intended to improve the lives of the poor and help them escape poverty. Many of these programmes are now operating at a national scale and cover millions of Indonesians. Using a new household survey dataset that covers the eastern areas of Indonesia (Indonesian Family Life Survey East 2012), this paper investigates the household-level determinants of access to social assistance programmes. The analysis reveals that social assistance programmes are relatively more available in poorer provinces and that poorer households - all things being equal - are more likely to access social assistance programmes than nonpoor households, which suggests that social assistance programmes in eastern Indonesia are successful in their efforts to target the poor (poverty targeting), both across regions and households. However, poverty targeting still has scope for improvement in terms of accuracy. Besides the poverty status (as measured in per capita consumption expenditures), the authors found that several other factors influence programme access. Having a disabled household member or having a household head who is a widow(er) appears to increase the likelihood of receiving social assistance programmes. Likewise, the level of trust and conflict in a community affects access to social assistance programmes. Particularly in the case of Raskin, the authors found that the programme is distributed more widely among those communities that are characterized by higher levels of conflict and lower levels of trust. The authors did not find that poor access to infrastructure and remoteness influences household access to social assistance programmes once they controlled for province fixed effects in the regression framework. Furthermore, the findings suggest that possession of a local 'poverty letter' strongly improves household access to social assistance programmes, even after controlling for a wide set of socioeconomic characteristics. In general, determinants of programme access differ significantly among provinces and between rural and urban areas. 


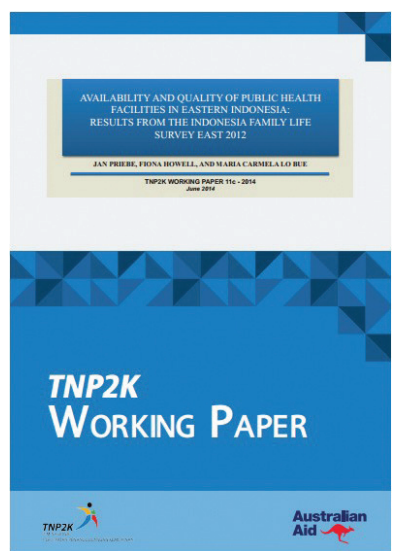

Working Paper 11c

Availability and Quality of Public Health Facilities in Eastern Indonesia : Results from the Indonesia Family Life Survey

East 2012

Author: Jan Priebe, Fiona Howell and Maria Carmela Lo Bue

Little is known about public health-care supply in Eastern Indonesia, a region that shows worse health outcomes than the rest of the country. Drawing on a new dataset (IFLS East 2012), this paper examines the availability and quality of public health-care facilities (puskesmas and posyandu) in Eastern Indonesia. The findings suggest that public health-care supply plays a larger and more important role in Eastern Indonesia compared with Western Indonesia. However, this stronger reliance and dependence on public health-care provision has not necessarily resulted in quality health-care supply. Although significant improvements have been achieved over time, the authors found that many puskesmas and posyandu could benefit from more and better-trained staff (education, training, availability, absenteeism) and better physical endowment (infrastructure, medical equipment, and medications). The results further suggest that remarkable differences in the provision of health care exist between urban and rural areas; urban areas have on average better-equipped puskesmas, whereas rural areas seem to have better-equipped posyandu. Furthermore, the authors found that direct funds from the central level (central government funds and Jamkesmas), despite the decentralization process, play a major role in financing the operations of public health facilities. In rural Eastern Indonesia, these central-level funds constitute about 80 percent of the total operational budget of a puskesmas.

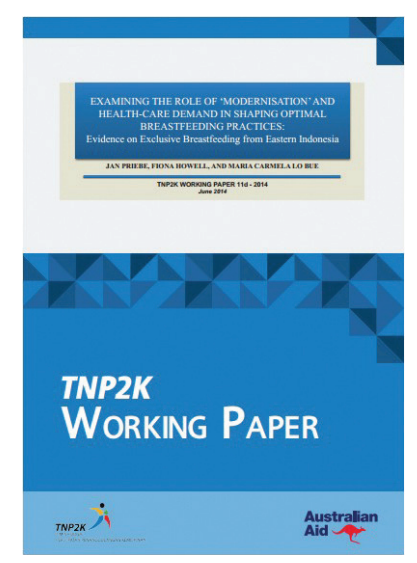

Working Paper 11d

Examining the Role of Modernisation and Healthcare

Demand in Shaping Optimal Breastfeeding Practices: Evidence on Exclusive Breastfeeding from Eastern Indonesia

Author: Jan Priebe, Fiona Howell and Maria Carmela Lo Bue

The health benefits to mothers and children in adopting optimal breastfeeding practices are well recognized. However, despite many efforts to promote optimal breastfeeding practices in developing countries, only modest progress has been achieved in past decades. This paper attempts to fill several important research gaps on the socioeconomic determinants of optimal breastfeeding. In contrast to previous studies that have focused on the timely initiation and duration of breastfeeding, this article examines exclusive breastfeeding practices. Using a new data set from Eastern Indonesia, the authors revisited the 'modernisation' hypothesis and, as a first study in this field, investigated to what extent health-care demand and supply factors influence optimal breastfeeding behaviours. Controlling for a wide range of individual, household, and community characteristics, the findings suggest that mothers' labour market participation under 'modern' employment contracts negatively affects optimal exclusive breastfeeding practices, and hence provide support for the 'modernisation' hypothesis. Moreover, the results indicate that a higher availability and quality of health-care supply does not necessarily lead to better breastfeeding practices. Only when health-care supply was matched with a significant demand for such services, did the authors observe a higher chance for optimal exclusive breastfeeding 


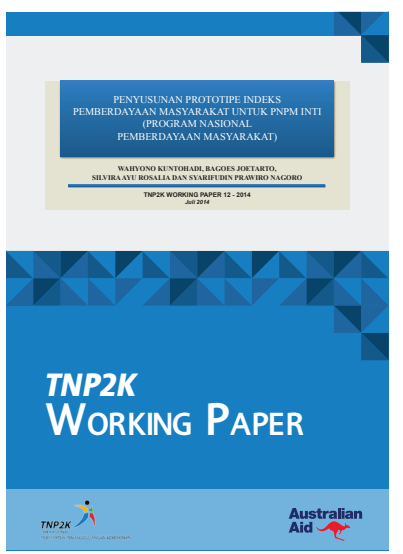

Working Paper 12

Penyusunan Prototipe Indeks Pemberdayaan Masyarakat untuk PNPM Inti (Program Nasional Pemberdayaan Masyarakat)

Author: Wahyono Kuntohadi, Bagoes Joetarto, Silvira Ayu Rosalia and Syarifudin Prawiro Nagoro

PNPM is a national program for community driven development and poverty reduction. To date the program has used output-based performance indicators for evaluation purposes. An index that effectively demonstrates the performance of the community empowerment process has not been used yet. An effective index is needed to monitor and evaluate activities given the large number of participants, the gradual empowerment process, and the tight schedules for field validation.

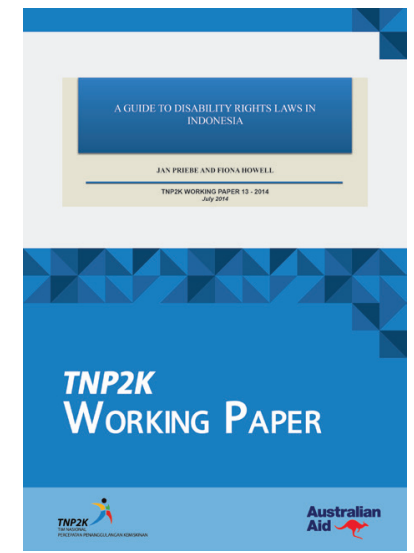

\section{Working Paper 13} A Guide to Disability Rights Laws in Indonesia

Author: Jan Priebe, Fiona Howell

In the past few decades, the Government of Indonesia has passed and signed a substantial number of domestic laws and international conventions/treaties that deal with the rights and opportunities of persons with disabilities (PWDs). Disability is a cross-cutting issue and requires an extensive review and monitoring of multiple pieces of legislation that have already been passed in or ratified by Indonesia. In this context, the objective of this report is to provide an overview for a broad audience of the crucial elements of the Indonesian legal framework on PWDs' rights. 


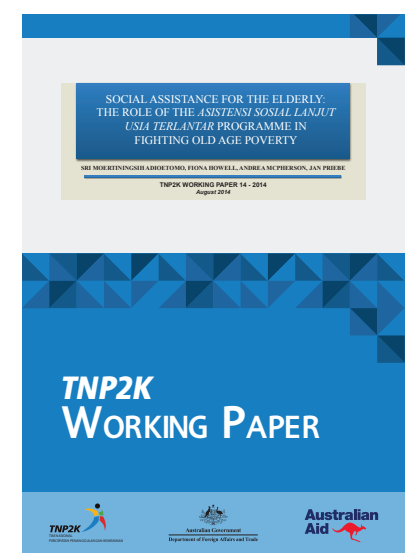

Working Paper 14

Social Assistance for the Elderly: The Role of the Asistensi

Sosial Lanjut Usia Terlantar Programme in Fighting Old Age

Poverty

Author: Sri Moertiningsih Adioetomo, Fiona Howell, Andrea

Mcpherson, Jan Priebe

Indonesia has undergone a demographic transition since the 1970s that has led to significant changes in the population age structure. Life expectancy increased from 45 years to 67 years. The number of elderly people (60 years and above) rose from about 5 million in 1970 to 18 million in 2010 , and is projected to increase to over 80 million by 2050 . The economic situation of the elderly is precarious. In 2012, 12.65 percent of older people (60 years and above) lived below the official poverty line. Older people, especially those aged 70 and above, have the highest poverty rate among all population groups, 14.92 percent. At the same time, a much greater proportion of the elderly population officially classified as poor is vulnerable to falling into poverty. Currently, the coverage of existing pension schemes for the elderly is very low. The proportion of older people in receipt of civil service and military pension schemes, the only formally available pensions in Indonesia, was 15.5 percent of the population aged 60 years and above in 2010 . These pension benefits, available to government workers, civil servants, military personnel and formal sector employees only, are usually insufficient to cover the basic needs of retirees. The Government of Indonesia has recognised these gaps in the social insurance schemes and is taking actions to improve pension coverage.

ASLUT, the current social assistance programme targeted directly at the elderly, started in 2006 in six provinces targeting 2,500 beneficiaries. It has subsequently expanded to all 34 provinces and increased the number of recipients to 26,500 beneficiaries in 2013 . Fighting old-age poverty: The role of ASLUT examines empirically, both quantitatively and qualitatively, the socio-economic conditions of poor elderly persons in Indonesia. In contrast to other reports, a particular focus is given to investigating the operations of ASLUT, Indonesia's only targeted cash transfer programme for the elderly. By doing so, the report draws on a unique household survey of 2,200 elderly households from 11 provinces which was conducted by SurveyMETER and the Demographic Institute of the University of Indonesia on behalf of TNP2K in 2012. 


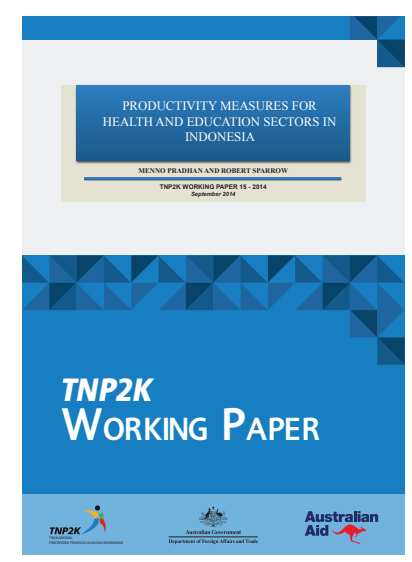

\section{Working Paper 15 \\ Productivity Measures for Health and Education Sectors in Indonesia}

Author: Menno Pradhan and Robert Sparrow

This study analyses the relative efficiency of district public health and education service delivery in Indonesia over the period 2003 to 2008. The authors production frontier models to assess the efficiency of districts in achieving education and health outputs, and costs functions to assess the efficiency of public spending. The analysis combines data from the Ministry of Finance on district spending, Susenas household surveys, and health and education infrastructure indicators from the PODES village census.

The data show a strong increase in district health and education public spending, as well as service availability. Yet, the authors also see a large disparity in spending between districts in terms of per capita public spending, both within and between regions. To a large extent this is driven by relatively static characteristics of districts. However, there is some evidence of convergence in spending levels as well as scope for local policy changes to overcome initial public spending differences. This suggests that the central government transfers remain an important policy tool for equalizing investment in health and education in districts.

The analysis reveals substantial variation in efficiency across regions in Indonesia. Given the level of service delivery, district public spending per capita is on average relatively low in Java and Bali. In contrast, Sulawesi and Kalimantan are relatively less efficient in terms of spending, while in Sumatra spending efficiency by district governments has declined strongly since 2006. Districts in Java and Bali also perform well in terms of technical efficiency, as service delivery in these districts is relatively high, given the level of spending and available infrastructure.

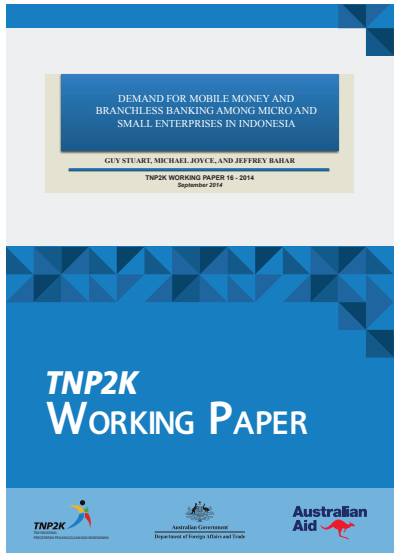

\section{Working Paper 16 \\ Demand for Mobile Money and Branchless Banking among Micro and Small Enterprises in Indonesia} Author: Guy Stuart, Michael Joyce, and Jeffrey Bahar

Micro and small enterprises (MSEs) represent a significant portion of Indonesia's economic and employment activity. They constitute 98 percent of all businesses and provide 94 percent of employment. MSEs represent the most significant portion of economic activity for the poor population of Indonesia; the poor are more likely than other income groups to use MSEs not only for employment and income generation but also for consumption. MSEs are therefore important links in the chain of financial inclusion and poverty reduction. By bringing more MSEs into the formal financial sector, it is expected that more of the poor population of Indonesia will also be provided with financial services.

The potential of mobile money and branchless banking (MM \& BB) services to provide financial services to previously "unbanked" market segments has been widely noted around the world, but this potential has not been realised in Indonesia. These services use a combination of new technology using mobile phones and agents as local service points to provide financial services to customers and locations that would otherwise be uneconomical to reach with conventional financial services.

This study assesses the potential demand for MM \& BB services from MSEs in Indonesia, drawing on both quantitative and qualitative data obtained through 400 survey interviews with MSE owners and 16 focus groups distributed evenly across four provinces: Bali, South Sumatra, South Sulawesi, and West Java. The study was conducted in August and September 2013. 

'Poverty and the Labour Market in Indonesia: Employment Trends across the Wealth Distribution', is among Indonesia's first papers on the relationship between poverty and the labour market. It provides a detailed analysis of employment indicators (labour force participation rates, hours worked, and type and sector of employment) for the period 2000-2012 across the entire wealth distribution, by location, gender and various sociodemographic characteristics.

Despite high economic growth rates, the creation of millions of new jobs, and a strong decrease in poverty rates in recent years, many Indonesians continue to live in poverty even when employed. This paper finds that the poor are as likely as the nonpoor to work, both at the extensive (labour force participation) and at the intensive (number of days and number of hours) margins. The reason for being poor despite being employed is therefore largely driven by other factors.

In terms of household structure, clear evidence exists that the working poor need to share their income with a larger household, including economically nonactive members such as young children and the elderly. The higher dependency ratio contributes to their being/becoming working poor.

Significant gender differences exist in the Indonesian labour market. Men show higher labour force participation rates and are more likely to work more hours compared with women. However, no strong gender differences were observed when comparing the working poor with the nonpoor.

The authors observed that the relative share of the rural working poor as a portion of all working poor has increased over time and that the majority of the working poor are employed in the agricultural sector. Furthermore, the working poor are predominantly and increasingly (in relative terms) concentrated in the informal sector of the economy.

An important finding concerns the role of education in the likelihood of being poor or nonpoor. Results also suggest that only the attainment of higher secondary and tertiary education seems to increase the likelihood of being meaningfully protected against poverty.

\section{TIM NASIONAL PERCEPATAN PENANGGULANGAN KEMISKINAN}

(TNP2K)

Jl. Kebon Sirih No. 35, Jakarta Pusat 10110

Tel: $\quad$ +62 (0) 213912812

Fax: $\quad$ +62 (0) 213912511

E-mail: info@tnp2k.go.id

Web: $\quad$ www.tnp2k.go.id 